\title{
Légkörkutatási célú fotoakusztikus spektroszkópián alapuló kétcsatornás vízgőzmérő rendszer fejlesztése
}

\author{
PhD értekezés
}

Szerző:

Tátrai Dávid

Fizika Doktori Iskola

Optikai és Kvantumelektronikai Tanszék

Szegedi Tudományegyetem, Természettudományi és Informatikai Kar

Témavezetők:

Prof. Dr. Szabó Gábor - egyetemi tanár

Dr. Bozóki Zoltán - tudományos tanácsadó

Szeged

2015 


\section{Tartalomjegyzék}

1 TARTALOMJEGYZÉK

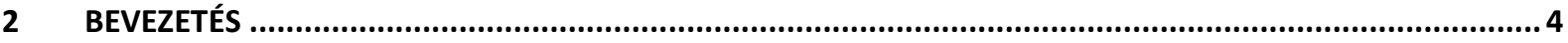

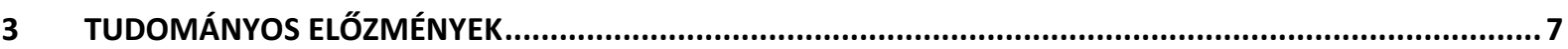

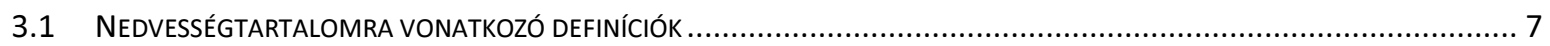

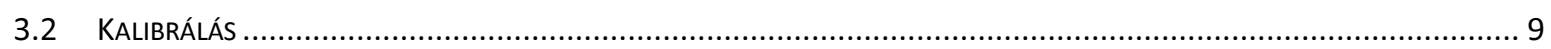

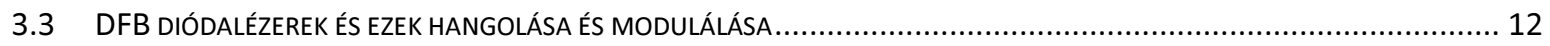

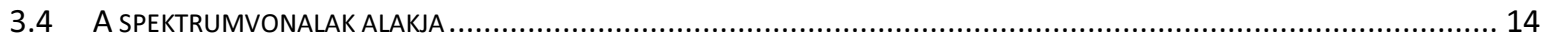

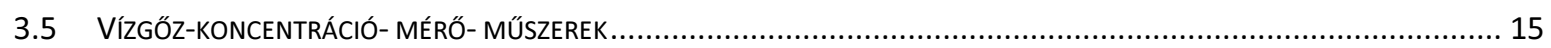

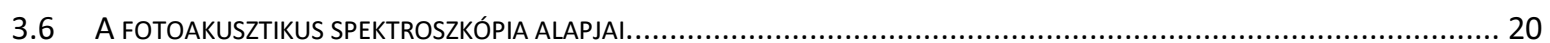

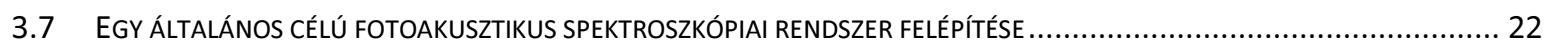

3.8 A SZEGEDI TUdOMÁNYEGYETEM ÉS A VIDEOTON HOLDING ZRT. EGYÜTTMŰKÖDÉSÉBEN KIFEJLESZTETT MÉRÉSVEZÉRLŐ

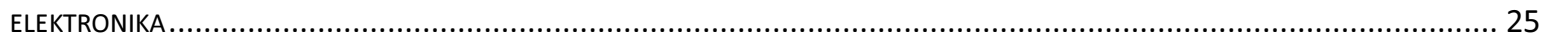

3.9 A SZEGEDI TUDOMÁNYEGYETEMEN FEJLESZTETT REPÜLŐGÉPRE TELEPÍTHETŐ VÍZGŐZMÉRŐK FEJLESZTÉSE ......................25

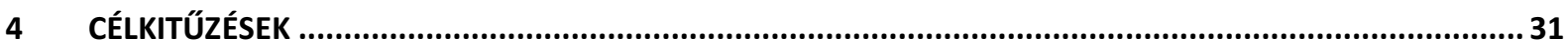

5 A MÉRŐRENDSZER ZAJFORRÁSAINAK ELEMZÉSE, KIKÜSZÖBÖLÉSE .......................................... 32

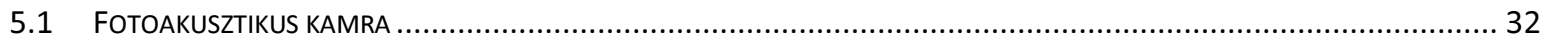

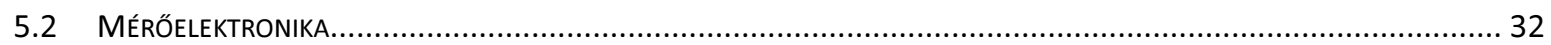

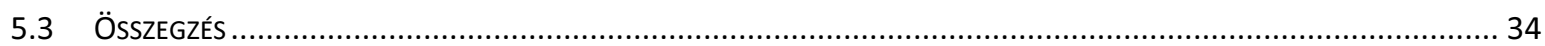

6 A HULLÁMHOSSZ BEÁLLÍTÓ ALGORITMUS PONTOSSÁGÁNAK JAVÍTÁSA.........................................36

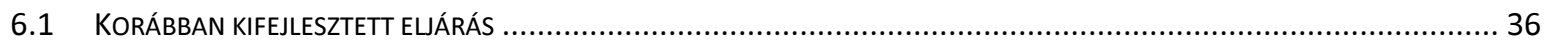

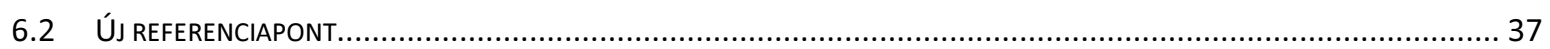

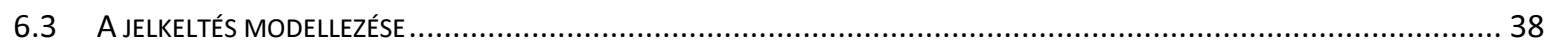

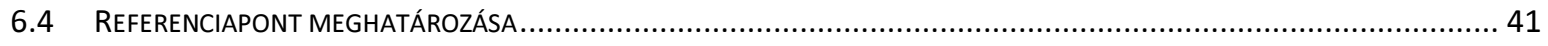

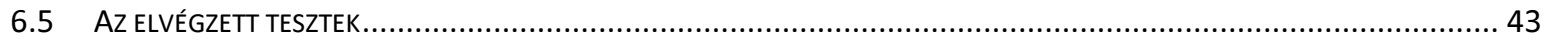

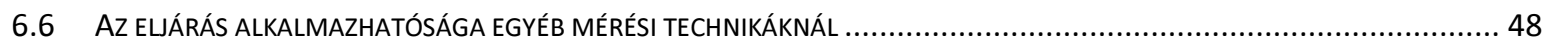

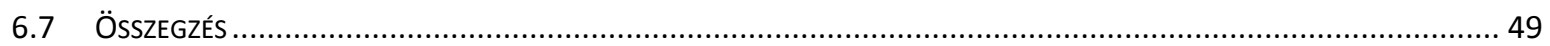

$7 \quad$ KALIBRÁCIÓS ÉS JELKIÉRTÉKELÉSI ELJÁRÁS FEJLESZTÉSE.....................................................50

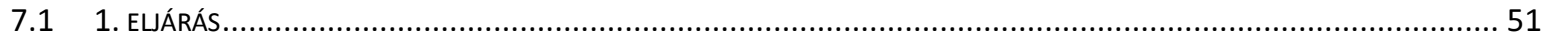

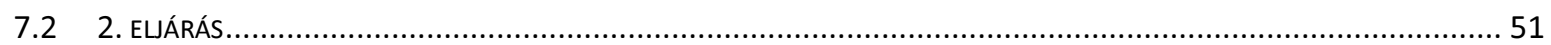

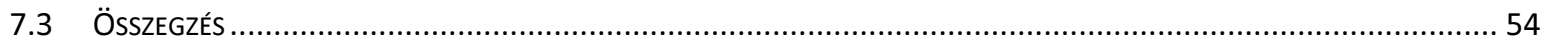

8 ÚJ MÉRŐRENDSZER TERVEZÉSE ÉS ÉPÍTÉSE FÜGGETLEN LABORATÓRIUMI ÉS REPÜLŐGÉPES

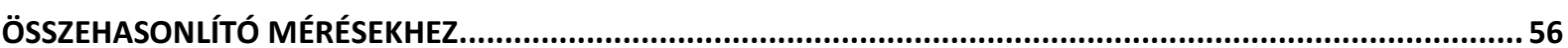




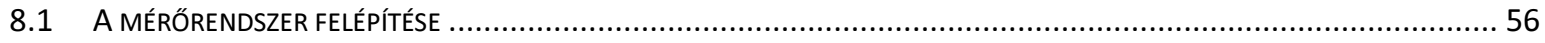

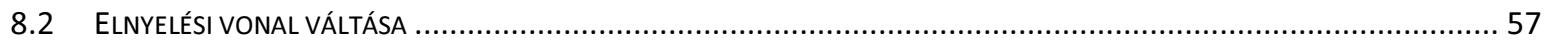

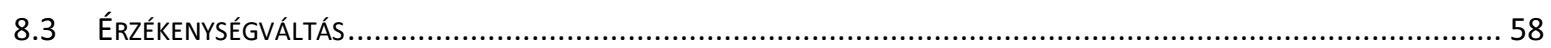

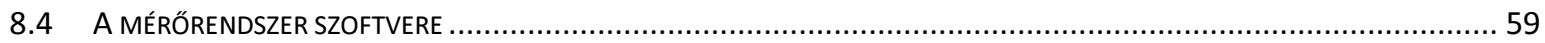

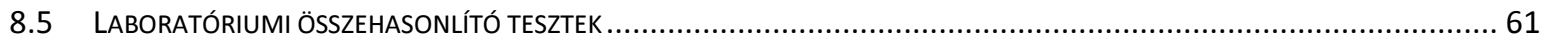

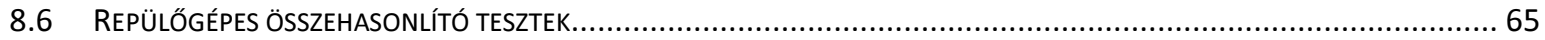

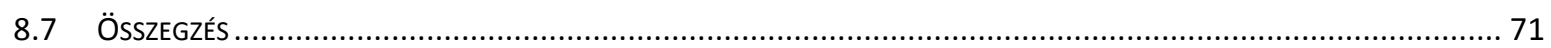

9 ÚJ ADATGYÜJTŐ ÉS MÉRÉSVEZÉRLŐ RENDSZER FEJLESZTÉSE .........................................................72

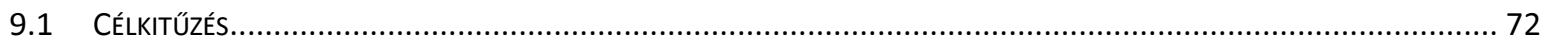

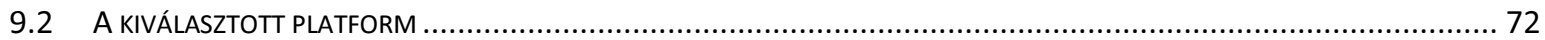

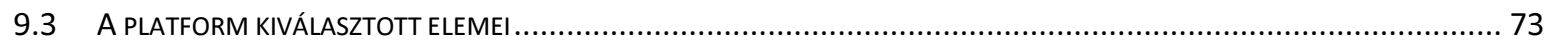

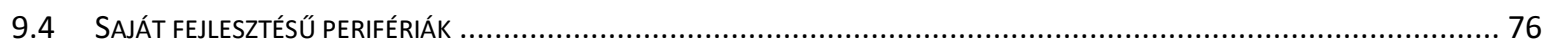

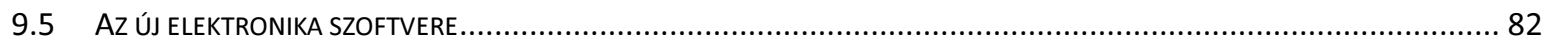

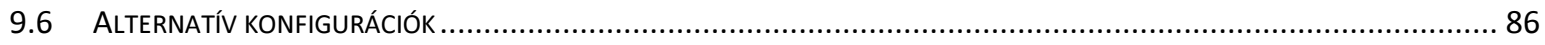

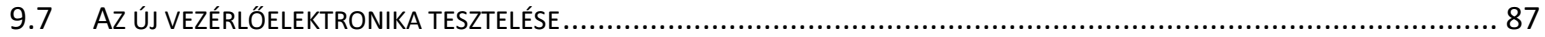

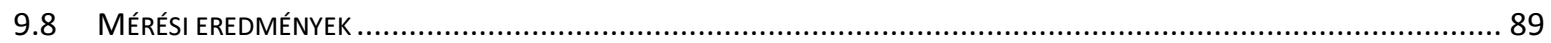

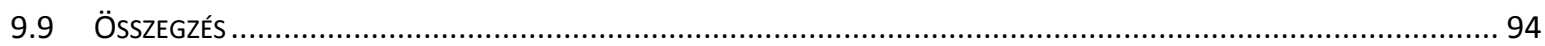

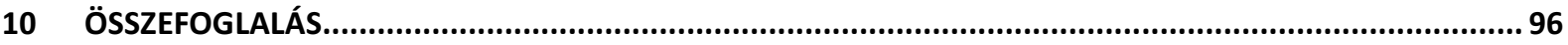

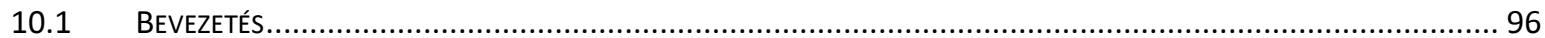

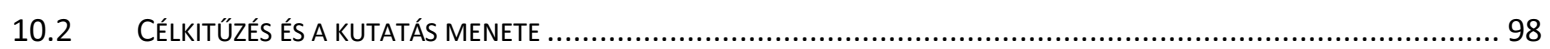

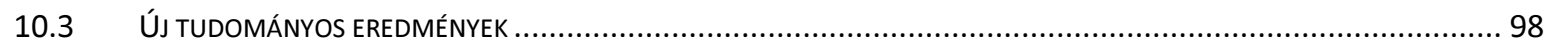

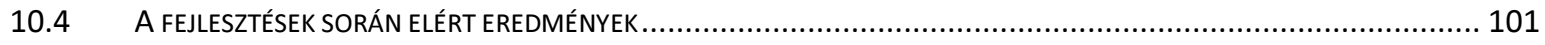

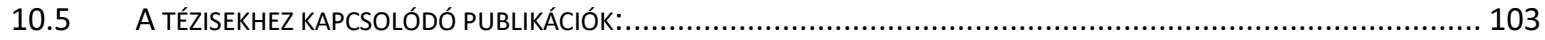

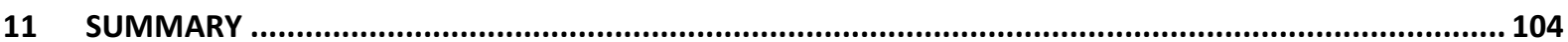

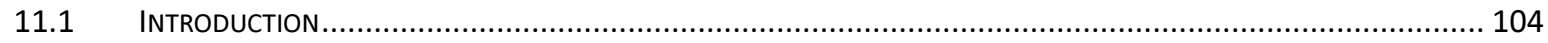

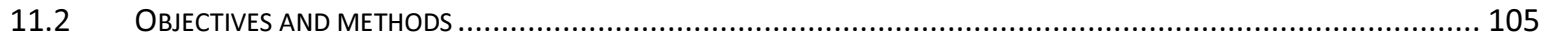

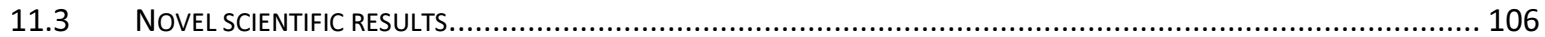

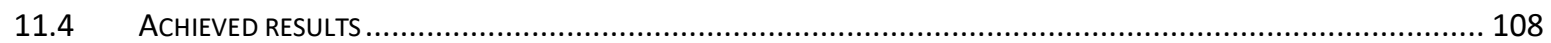

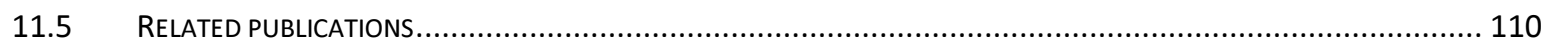

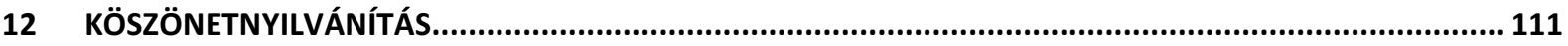

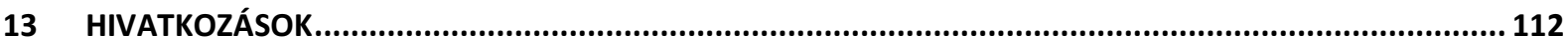




\section{Bevezetés}

Napjaink egyik legfontosabb, minden ember életét érintő kérdése a globális klímaváltozás, hogy ez milyen mértékben természetes folyamat (vulkánkitörések, naptevékenység hatása...), mennyiben tehető érte felelőssé az emberiség illetve, hogy van-e esély a változások visszafordítására. A klímaváltozás legfőbb okozójaként a mesterséges széndioxid- kibocsájtást szokás a legnagyobb problémaként megjelölni, hivatkozva arra, hogy a légköri széndioxid koncentráció az elmúlt 50 évben hozzávetőlegesen 30\%-kal emelkedett [1]. Hasonló trend figyelhető meg a szintén gyakran emlegetett metán esetében is [2]. Ezek mellett viszont csak ritkán kerül szóba a levegő nedvességtartalma okozta üvegházhatás, holott mintegy 75\%-át okozza 2:1 arányban a gáznemú és a felhő víztartalom. Alig ismert és ennek megfelelően nem is emlegetett tény, hogy a sztratoszférában az elmúlt 50 évben az átlagos vízgőz-koncentráció hozzávetőlegesen kétszeresére nőtt [3], tehát azokon a területeken koncentrációjának a növekedése háromszor gyorsabb, mint a széndioxidé vagy a metáné. Ezt a gyors növekedését okozhatja akár a melegedő óceánok gyorsabb párolgása, akár pedig a megnövekedett mértékű légi közlekedés, hiszen az utasszállító repülőgépek a troposzféra-sztratoszféra határán repülve jelentős mennyiségű vízgőzt juttatnak a légkörbe. Ez utóbbit alátámasztja az is, hogy a légi közlekedés klímára gyakorolt hatásának vizsgálata során kiderült, hogy a kondenzcsíkoknak és az azokból kialakuló cirrusz felhőknek jelentősebb az üvegházhatása, mint a kerozin égetésekor keletkező széndioxidnak [4-10].

A légkör teljes modellezése annak összetettsége, bonyolultsága, kaotikus viselkedése, valamint a rendelkezésre álló, nem kellően pontos és nagy felbontású mérési eredmények miatt jelenleg lehetetlen feladat. A modellezési képességek fejlődését mutatja, hogy nemrégiben két kutatócsoport egymástól függetlenül, különböző módszerekkel hasonló eredményre jutott, mikor kísérletet tettek a globálisan kinyerhető szélenergia mennyiségének meghatározására [11, 12]. Az ismereteink növekvő pontosságát mutatják az egyre hosszabb távon is egyre megbízhatóbb meteorológiai előrejelzések is. Ismereteink azonban továbbra is korlátozottak, a légkörben lejátszódó folyamatok pontosabb megismerését jelenleg elsősorban a megbízható, nagy tér és időfelbontású mérési adatok hiánya hátráltatja. Ez különösen igaz a nedvességtartalomra, mivel annak tér és időbeli eloszlása a leginkább inhomogén. 
A fentiek miatt igen fontos feladat lenne a légköri vízgőz-koncentráció és teljes víz tartalom (vízgőz és vízcseppek/jégkristályok) folyamatos nagy tér és időbeli felbontással való monitorozása.

A légkör monitorozásának négy fő platformja van: földi megfigyelőállomások, meteorológiai ballonok, kutató-repülőgépek és műholdak. Mind a négy platform más-más célú megfigyelésekre alkalmas, mindnek meg van a saját alkalmazási területe, a globális megfigyelések során egymás kiegészítői lehetnek [13].

Az 1950-es '60-as évek óta számtalan kutató-repülőgépes mérést végeztek el, azonban ezek technikai és finanszírozási korlátok miatt csak lokális, speciális célú megfigyelések voltak [1416]. Az 1980-as években merült fel komolyan a gondolat, hogy utasszállító repülőgépekre különböző műszereket telepítve létre lehetne hozni egy globális légkör-monitorozó hálózatot. Azóta három jelentős lépés történt az ötletnek a valóra váltásában: 1994-ben elindult a MOZAIC ${ }^{1}$ projekt [17], melynek keretein belül több, mint 300000 órányi repülés alatt mérték a légkör ózon, vízgőz, szén-monoxid és nitrogén-oxid tartalmát mind 9-12 km-es repülési magasságban, mind pedig függőleges profilokban a fogadó repülőterek környezetében. A következő jelentős lépés a CARIBIC² projekt [18], mely 2004-ben indult. Ennek keretein belül a Lufthansa vállalta, hogy havonta négy menetrend szerint közlekedő interkontinentális járaton mintegy másfél tonnás összsúllyal számos mérőmúszert szállít és üzemeltet. Ebbe a projektbe a Szegedi Tudományegyetem is be tudott kapcsolódni két fotoakusztikus (PA) elvű kétcsatornás nedvességtartalom- mérő- műszer biztosításával [19]. A jelenlegi nagy lépés a IAGOS ${ }^{3}$ projekt [20] indulása, melynek keretein belül több légitársaság kisebb, mindössze 5-10 múszert tartalmazó csomagokat telepít repülőgépeire, azonban a CARIBIC projekttel szemben ezek a műszerek az adott repülőgép minden egyes repülése alatt üzemelni fognak. Jelenleg mind a MOZAIC, mind pedig a CARIBIC projekt adminisztratív szempontból a IAGOS részét képezi.

Ezen projektek sikerének két kulcsa van: egyrészt olyan múszerekre van szükség, melyek amellett, hogy eleget tesznek az igen szigorú biztonsági előírásoknak, a költségminimalizálás

\footnotetext{
${ }^{1}$ Measurements of OZone, water vapour, carbon monoxide and nitrogen oxides by in-service Alrbus airCraft

${ }^{2}$ Civil Aircraft for the Regular Investigation of the atmosphere Based on an Instrumented Container

${ }^{3}$ In-service Aircraft for a Global Observing System
} 
érdekében minél kisebbek, könnyebbek, képesek pontosan megbízhatóan, felügyelet nélkül múködni éveken át. Másrészt pedig szükség van egy olyan intézményrendszerre, nemzetközi kutatócsoportra, amely a mérési eredmények feldolgozását, az eredményekre alapozva a légkör és klímamodellek tökéletesítését el tudja végezni.

Annak ellenére, hogy egye több cég gyárt kifejezetten repülögépekre tervezett mérőműszereket [21-26], az általános műszerezettség mind a mai napig megoldatlan [27, 28]. A feladat összetettségét mutatja, hogy a jelentősebb légkörkutatással is foglalkozó intézetek saját műszereket is fejlesztenek [29-34], melyek között számos vízgőz-koncentráció- mérő is található. Ennek ellenére a kutatócsoportunk által fejlesztett műszeren kívül csak egyről van tudomásom, amit kifejezetten vízgőz-koncentráció és teljes víz tartalom egyidejű mérésére terveztek [35], azonban az a műszer mind tömegben, mind térfogatban két és félháromszorosa az általunk fejlesztettnek, miközben csak 1000 ppmV-nél kisebb koncentrációk esetén használható. A műszerezettségi probléma komolyságát mutatja, hogy az Európai Unió elindította az EUFAR ${ }^{4}$ [36] projektet, amelynek egyik célja különböző célú műszerek versenyszerű fejlesztésének a támogatása. Egyik részprojektjébe, a DENCHAR ${ }^{5}$-ba a Szegedi Tudományegyetem Optikai és Kvantumelektronikai Tanszéke is be tudott kapcsolódni a CARIBIC projektben is alkalmazott PA elvű kétcsatornás nedvességtartalom mérő műszerek továbbfejlesztésével, tökéletesítésével. Ennek a munkának az elvégzése képezi doktori értekezésem alapját.

A röviden bemutatott nagy projektek mellett természetesen továbbra is folynak kutatórepülőgépes mérések [14-16, 37-39], melyeket a repülési útvonalaktól távolabb eső területeken illetve speciálisan érdekes területek, jelenségek részletes vizsgálata során alkalmaznak. A technika fejlődésével egyre nagyobb jelentőségűek a drónokon végzett mérések, melyeknek a jelenlegi technológiai csúcsát a Northrop Grumman által részben katonai célra fejlesztett Global Hawk [40] adja, amely a NASA egyik állandó légkörkutatási platformja is egyben.

\footnotetext{
${ }^{4}$ European Facility for Airborne Research

${ }^{5}$ Development and Evaluation of New and Improved Hygrometers for Airborne Research
} 


\section{Tudományos előzmények}

\subsection{Nedvességtartalomra vonatkozó definíciók}

\section{Abszolút páratartalom}

Abszolút páratartalomnak nevezzük az $1 \mathrm{~m}^{3}$ térfogatú gázban lévő vízgőz tömegét $\left(\mathrm{g} / \mathrm{m}^{3}\right)$.

\section{Keverési arány}

A keverési arányt megadhatjuk térfogatra vagy tömegre vonatkoztatva, értéke megadja, hogy az adott gázelegy térfogatának/ tömegének hányad részét adja vízgőz $\left(p p m V^{6}\right)$. A légköri mérések során leggyakrabban térfogatra vonatkoztatott keverési arányt szokás megadni. A továbbiakban a keverési arányra koncentrációként fogok hivatkozni.

\section{Harmatpont}

Harmatpontnak nevezzük azt a hőmérsékletet, amelynél az adott abszolút páratartalmú gáz azonos teljes nyomáson vízgőzre nézve telítetté válna. A harmatponthoz tartozó telített gőznyomás értékét a hőmérséklet függvényében a víz fázisdiagramjában (Ábra 1) a gáz és a szilárd/folyadékfázist elválasztó görbe adja. A görbe pontos leírása igen összetett feladat [41, 42], hiszen a görbe alakját nem csak a hőmérséklet határozza meg, hanem az is, hogy cseppfolyós vagy szilárd fázisú felszín feletti-e a vizsgált gázelegy. A későbbiekben a számos matematikai modell közül a Goff-Gratch egyenletet [43-45] alkalmaztam:

$$
\begin{gathered}
\left.\log _{10} p_{\text {sat }}\right|_{\text {viz }}=-7,90298 \cdot\left(\frac{373,16}{T}-1\right)+5,02808 \cdot \log _{10} \frac{373,16}{T}- \\
-1,3816 \cdot 10^{-7} \cdot\left(10^{11,344 \cdot\left(1-\frac{373,16}{T}\right)}-1\right)+8,1328 \cdot 10^{-3} \cdot\left(10^{3,49149 \cdot\left(1-\frac{373,16}{T}\right)}-1\right)+ \\
+\log _{10} 1013,246 \\
\left.\log _{10} p_{\text {sat }}\right|_{\text {jég }}=-9,09718 \cdot\left(\frac{273,16}{T}-1\right)-3,56654 \cdot \log _{10} \frac{273,16}{T}+ \\
+0,876793 \cdot 10^{-7} \cdot\left(1-\frac{T}{273,16}\right)+\log _{10}(610,71)
\end{gathered}
$$

\footnotetext{
${ }^{6}$ parts per mililon by volume, azaz milliomod térfogatrész
} 
ahol $\boldsymbol{p}_{\text {sat }}$ a telített gőznyomás (mbar), $\boldsymbol{T}$ pedig a hőmérséklet (K).

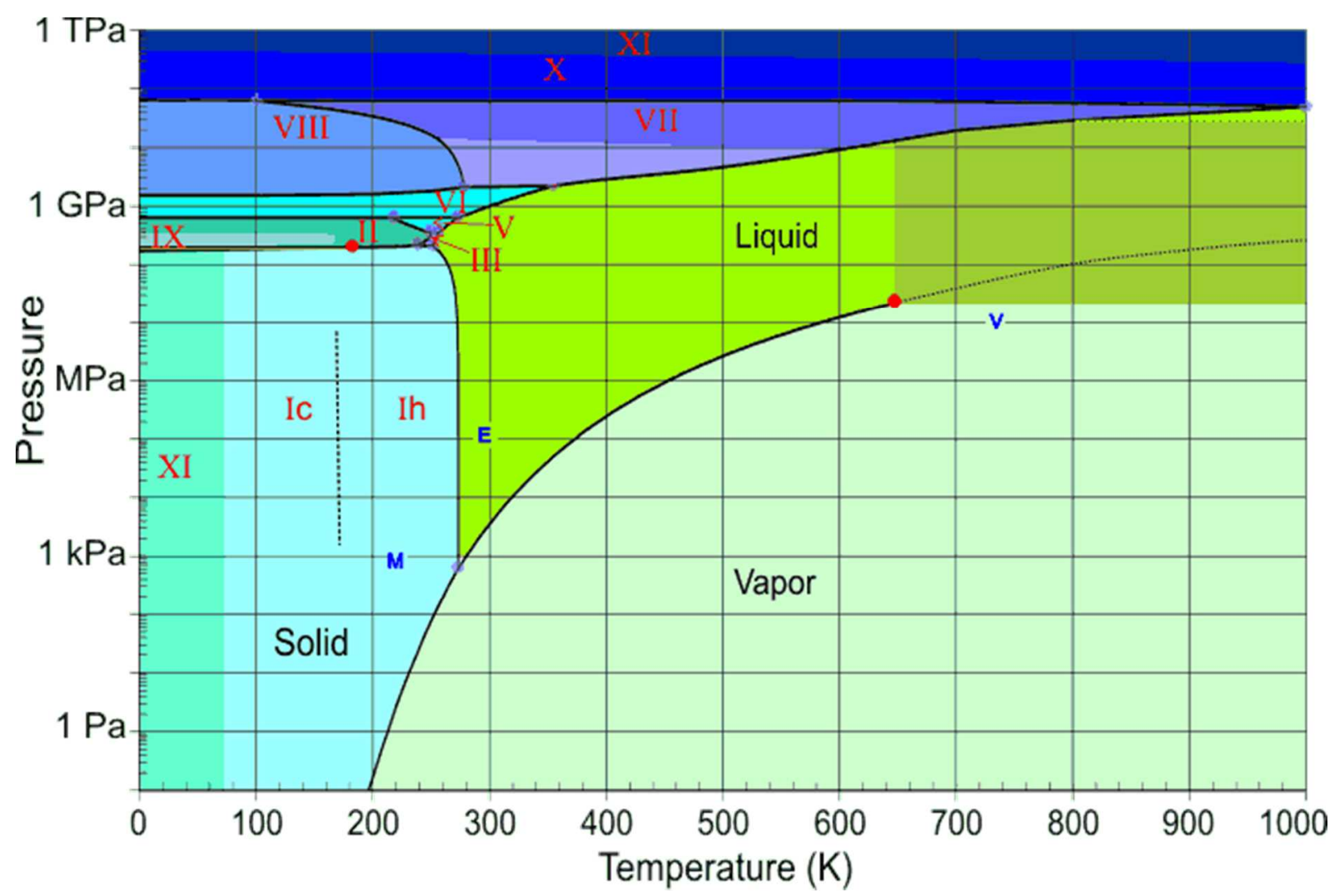

Ábra 1: A víz fázisdiagramja. /temperature: hömérséklet; pressure: nyomás; solid: szilárd; vapor: göz; liquid: folyadék; Az egyéb rövidítések és római számok a különbözö kristályszerkezeteket jelölik./ A kép forrása: [46].

\section{Relatív páratartalom}

A relatív páratartalom megadja, hogy az aktuális abszolút páratartalom hány százaléka a gáz hőmérsékletéhez és nyomásához tartozó telített gőznyomású gázelegy abszolút páratartalmának.

\section{Vízgőz-tartalom}

Vízgőz-tartalom alatt a vizsgált légtömeg gázfázisú részének keverési arányát vagy abszolút páratartalmát értjük.

\section{Teljes víz tartalom}

Teljes víz tartalomnak a vizsgált légtömeg egészét (gázfázis és az esetlegesen jelenlévő cseppfolyós/kristályos/aeroszolon megkötött víz) elpárolgás esetén jellemző keverési arányt vagy abszolút páratartalmat nevezzük. 


\subsection{Kalibrálás}

A vízgőz-koncentráció- mérő- műszereket megfelelő pontosságú működésük biztosításához kalibrálni kell, ami - összehasonlítva hőmérséklet vagy nyomás mérésével - általában igen komoly kihívást jelent. A legfőbb nehézséget - egyéb gázszenzorokhoz képest - az jelenti, hogy nem lehet olyan gázpalackot készíteni, amiben kellően magas vízgőz-koncentráció lenne, hogy hígítással a teljes érdekes tartományt (1-40000 ppmV) le lehessen fedni. Valamint kis koncentrációk esetén igen komoly kihívás, hogy a csövek, maga a mérőeszköz belső faláról deszorbeálódó, vagy a csövek falán átdiffundáló víz ne okozzon szisztematikus vagy véletlenszerű kalibrálási/mérési problémát. A probléma jelentőségét jelzi, hogy nemrégiben a MOZAIC projektben mért 15 évnyi vízgőz-koncentráció adatot újra ki kellett értékelni, miután kiderült, hogy a szenzorok kalibrálásához használt elrendezésben - annak karbantartásakor két termisztor bekötését felcserélték [47]. A különböző műszerek működési elvükből adódó artefaktumok, kalibrációjuk pontatlanságából adódó szisztematikus hibák következtében - főként kis koncentrációk esetén - jelentős mértékben, akár 20-50\%-kal is eltérhetnek egymástól, mint ahogyan az NASA Crystallface és MACPEX mérési kampányokban is kiderült $[48,49]$. Részben a hasonló hibák kiküszöbölésére, feltárására az $\mathrm{FZK}^{7}$ (ma KIT ${ }^{8}$ ) AIDA ${ }^{9}$ légkörszimulációs kamrájánál 2007-ben megszervezték az AquaVIT mérési kampányt [50-52], amely során a $\mathrm{PTB}^{10}$ metrológiai támogatásával hasonlítottak össze vezető légkörkutatási intézmények által fejlesztett vízgőz-koncentráció- mérő- műszereket. Ezen kutatócsoportunk is részt vett műszerünk egy korai változatával. 2013-ban Ugyanott, hasonló körülmények között megszervezték az AquaVIT-2 mérési kampányt [53], amelyen az általam elvégzett fejlesztésekkel frissített múszerünkkel vettem részt. Az összehasonlító eredmények azt mutatják, hogy a fejlesztések eredményesek voltak, további részleteket azonban a kampány adatkezelési protokollja miatt a dolgozat elkészítésekor nem közölhetek.

\subsubsection{Kalibrálási technikák}

Mint korábban említettem, vízgőz-koncentráció- mérő- műszerek kalibrálásához nem lehet referencia-gázpalackot vásárolni, ezért kalibrálás során a felhasználónak kell előállítania a

\footnotetext{
${ }^{7}$ Forschungszentrum Karlsruhe, ma Karlsruhe Insitute of Technology (Németország)

${ }^{8}$ Karlsruhe Institute of Technology

${ }^{9}$ Aerosol Interaction and Dynamics in the Atmosphere

${ }^{10}$ Physikalisch-Technische Bundesanstalt (Németország)
} 
megfelelő nedvességtartalmú gázt. Ezt különböző nedvességgenerátorok segítségével lehet megtenni, melyek közül egyszerúségük miatt a leggyakrabban alkalmazottak a különböző, telített gőzt előállító elrendezések. Ezeknél lényegesen pontosabbak a gravimetriai, Coulometriai vagy permeáción alapuló múszerek [54], melyeket összetettségük miatt elsősorban nem kalibrációs, hanem metrológiai referenciaként alkalmaznak.

\subsubsection{Telített gőz előállításán alapuló technikák}

Ha kellően alacsony sebességgel vízen átbuborékoltatunk levegőt, vagy víz/jégfelszín felett elvezetjük akkor az vízgőzzel telítődni fog. A kapott gáz vízgőz-koncentrációját csak a hőmérséklet és a nyomás határozza meg. Ha relatív páratartalom kalibráció elvégzése a cél, akkor a kilépő gáz nyomását lecsökkentve, vagy hőmérsékletét növelve lehet azt a 100\%-ról csökkenteni. Ezek az úgynevezett kétnyomásos vagy kéthőmérsékletes nedvességgenerátorok. Ha a vízgőzzel telített levegőt például tömegáramlás-szabályozók segítségével, szárazzal keverjük, akkor nem csak a relatív, hanem az abszolút páratartalmat is lehet csökkenteni.

Ezek az elrendezések azért előnyösek, mert a hőmérséklet, nyomás és az áramlási sebességek mérésével meghatározható a koncentráció pontos értéke. A hígításos technikáknál igen fontos, hogy a hígító gáz abszolút páratartalma alacsony, lehetőség szerint ppb-ppt szintű legyen. Ez igen nehezen kivitelezhető, ezért gyakori, hogy egy referencia szenzorral, tipikusan egy tükrös harmatpontmérővel (3.5.1) is monitorozzák a nedvességgenerátort.

\subsubsection{SZTE nedvességgenerátor}

A kutatócsoportunkban kifejlesztett, az $\mathrm{OMH}^{11}$ által hitelesített nedvességgenerátor (Ábra 2) is telített gőz előállításán alapul. Benne a szaturátor egy vörösréztömbben kialakított csigavonal alakú pálya, amelyen keresztülvezetjük a kalibráláshoz használt vivőgázt (szintetikus levegőt). A csigavonal alján annak hőmérsékletétől függően cseppfolyós víz vagy jég található, amely párolgása/szublimációja révén nedvesíti a vivőgázt. A szaturátorhoz egy alumínium nyelv van erősítve, melyet a mérés kezdetén folyékony nitrogénbe merítünk. Ennek hatására a szaturátor $-150{ }^{\circ} \mathrm{C}$ körüli hőmérsékletre húl le és onnan lassan, mintegy másfél nap alatt melegszik fel szobahőmérsékletre. Ezalatt az idő alatt a szaturátor

\footnotetext{
${ }^{11}$ Országos Mérésügyi Hivatal
} 
hőmérsékletét egy PT100 ellenállás hőmérővel mérve (kalibrációs faktorok erejéig) megkapjuk a szaturátorból kilépő gáz harmatpontját. A rendszer megbízhatóan nagyjából 10 ppmV-nél magasabb koncentrációk esetén múködik, ám alatta is \pm 1 ppmV erejéig konzisztensen múködik.

Fontosnak tartom megjegyezni, hogy a kalibráláskor használt referenciamúszer nem tartoznak a világ élvonalába sem pontosság, sem precizitás tekintetében, ugyanakkor az élvonalba tartozó azonos típusú műszerek között is több százaléknyi eltérés is lehet ${ }^{12}$. Ennél jelentősebb pontosságot csak a $\mathrm{NIST}^{13}$, NMIJ ${ }^{14}$, NPL ${ }^{15}$ vagy a PTB vízgőz referenciaműszereivel lehet elérni.
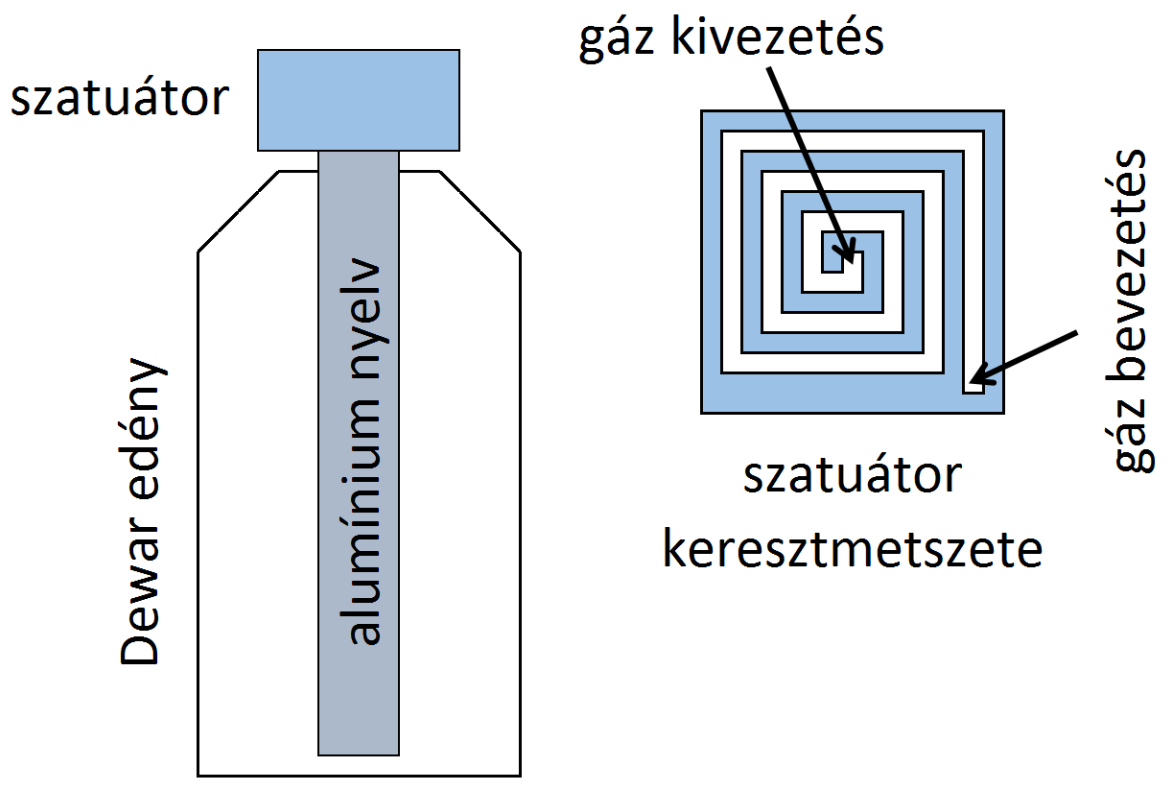

Ábra 2: A kalibrációs mérések során is alkalmazott nedvességgenerátor.

\footnotetext{
12 Az AquaVIT-2B mérési kampány (2013 április-május, Karlsruhe, Németország; Karlsruhe Institute of Technology) eredményei alapján, melyek az adatkezelési protokoll szerint a dolgozat benyújtásakor még nem hozhatóak részleteikben nyilvánosságra.

${ }^{13}$ National Institute of Standards and Technology (USA)

${ }^{14}$ National Metrology Institute of Japan (Japán)

${ }^{15}$ National Physical Laboratory (Egyesült Királyság)
} 


\subsection{DFB diódalézerek és ezek hangolása és modulálása}

A vizsgálataim során közeli infravörös tartományban múködő elosztott visszacsatolású (DFB $\left.{ }^{16}\right)$ dióda lézereket $[55,56]$ használtam, ezért most csak ezek hangolhatóságát és modulálhatóságát mutatom be, de a megállapítások többsége igaz a $\mathrm{DBR}^{17}$ dióda lézerekre és a VCSELL ${ }^{18}$-ekre egyaránt.

A DFB dióda lézereket elsősorban telekommunikációs célra fejlesztettél ki. Ezekben az alkalmazásokban alapvető fontosságú a hosszútávon is stabil megbízható múködés, az ITU-T [57] ajánlás hullámhosszaira való beállithatóság miatti kismértékú hangolhatóság, a keskeny vonalszélesség valamint a modulálhatóság. A telekommunikációs felhasználásra való tervezésüknek köszönhetően természetesen adódik, hogy ezek a lézerek optikai szálba csatoltan is kaphatóak. Jelenleg a telekommunikációs ablakon túl is a 700-3000 nm-es tartományban gyártanak DFB dióda lézereket, melyeket egészen $2300 \mathrm{~nm}$-ig szálba is tudnak csatolni [58]. Ezen hullámhossz felett a jelenleg elérhető optikai szálak alkalmatlanok precíziós műszerben való alkalmazásra [59, 60]. Újabban a közép-infravörös tartományban múködő interband-cascade és kvantum-kaszkád lézerek is készülnek DFB kivitelben nagyjából $15 \mu \mathrm{m}$ es hullámhosszig $[56,61]$.

A DFB dióda lézerekben a hullámhossz-kiválasztást egy, az aktív anyagában létrehozott Braggrács végzi el, így a hullámhossz beállításához a Littrow vagy Littman elrendezésú külső rezonátoros [62] elrendezésekkel szemben nem szükséges/lehetséges az egyes optikai elemeket mozgatni. A hullámhosszat a Bragg rács effektív rácsállandójának megváltoztatásával lehet beállítani, ezt a lézer hőmérsékletének és a müködtetéshez szükséges áramerősség megváltoztatásával lehet elvégezni. A hangolás fizikai háttere számos lézerfizika és optoelektronika témájú könyvben is részletesen bemutatásra került [63, 64].

Az aktív anyag hőmérsékletét, így hullámhosszát egy, a lézerbe integrált Peltier-cella segítségével megfelelő visszacsatolás (NTC ${ }^{19}$ termisztor, $\mathrm{PI}(\mathrm{D})^{20}$ algoritmus) mellett lehet stabilizálni illetve szükség szerint megváltoztatni. A lézeren átfolyó - a müködéshez

\footnotetext{
${ }^{16}$ Distributed FeedBack

${ }^{17}$ Distributed Bragg Reflector

${ }^{18}$ Vertical Cavity Surface Emitting Laser

${ }^{19}$ Negative Temperature Coefficient

${ }^{20}$ Proportional-Integrating-Derivating
} 
szükséges - áramerősség a hullámhossz pontos beállításához, kismértékü, de gyors hangolásához, modulálásához használható. A hangolhatóságot az alábbi egyenlet írja le:

$$
\lambda=\lambda_{0}+a \cdot T+b \cdot I
$$

ahol $\boldsymbol{a}$ a hőmérséklet hangolási együttható $(\mathrm{nm} / \mathrm{mA})$, melynek tipikus értéke $0,1 \mathrm{~nm} / \mathrm{mA}, \boldsymbol{T}$ a Peltier-cellával beállított hőmérséklet ${ }^{\circ} \mathrm{C}$-ban mérve, $\boldsymbol{b}$ az áramhangolási együttható $(\mathrm{nm} / \mathrm{mA})$, melynek tipikus értéke $5 \mathrm{pm} / \mathrm{mA}, I$ a lézeren átfolyó áramerősség $(\mathrm{A}), \lambda_{0}$ pedig a $0{ }^{\circ} \mathrm{C}$-hoz, és $0 \mathrm{~mA}$ áramerősséghez tartozó „virtuális” hullámhossz $(\mathrm{nm})$. Ezen felül fontos, hogy a lézer teljesítménye nagyban függ a rajta átfolyó áramerősségtől. Egy minimális bekapcsolási küszöb elérése után a teljesítmény lineárisan növekszik az áramerősséggel a normális működési tartományon belül:

$$
P_{\text {laser }}(I)=P_{0}+j \cdot I
$$

ahol $\boldsymbol{P}_{0}$ a $0 \mathrm{~mA}$ áramerősséghez tartozó negatív virtuális teljesítmény $(\mathrm{W}), \boldsymbol{j}$ a bekapcsolási küszöb-áramerősség felett a teljesítmény-áramerősség görbe jó közelítéssel állandónak vehető meredeksége (W/A), melynek tipikus értéke 0.1-10 W/A tartományba esik. Fontos megjegyezni, hogy a $\lambda_{0}, \boldsymbol{P}_{0}, \boldsymbol{a}, \boldsymbol{b}, \boldsymbol{d}$ paraméterek még azonos gyártási sorozatból származó lézereknél sem egyeznek meg, sőt egy adott lézerre jellemző $\lambda_{0}$ értéke lassan változik az időben.

Az integrált Peltier-cellával csak lassan lehet változtatni a hőmérsékletet, ezért ez csak hullámhossz-stabilizálásra és lassú változtatásra alkalmas. Ennek megfelelően a hőmérséklet léptetésével változtatva a hullámhosszat spektrumot lehet felvenni. Innen ered a gyakran használatos „10-30 ${ }^{\circ} \mathrm{C}$ tartományon felvett spektrum” kifejezés.

A lézer áramerőségének változtatásával igen gyorsan, jellemzően nanoszekundumos időskálán változik annak mind a hullámhossza, mind pedig a teljesítménye. Így megfelelő modulációs paraméterek mellett amplitúdó és hullámhossz-modulációt is el lehet érni. Ezekre a PA spektroszkópia alapjait bemutató 3.6 fejezetben térek ki részletesen. 


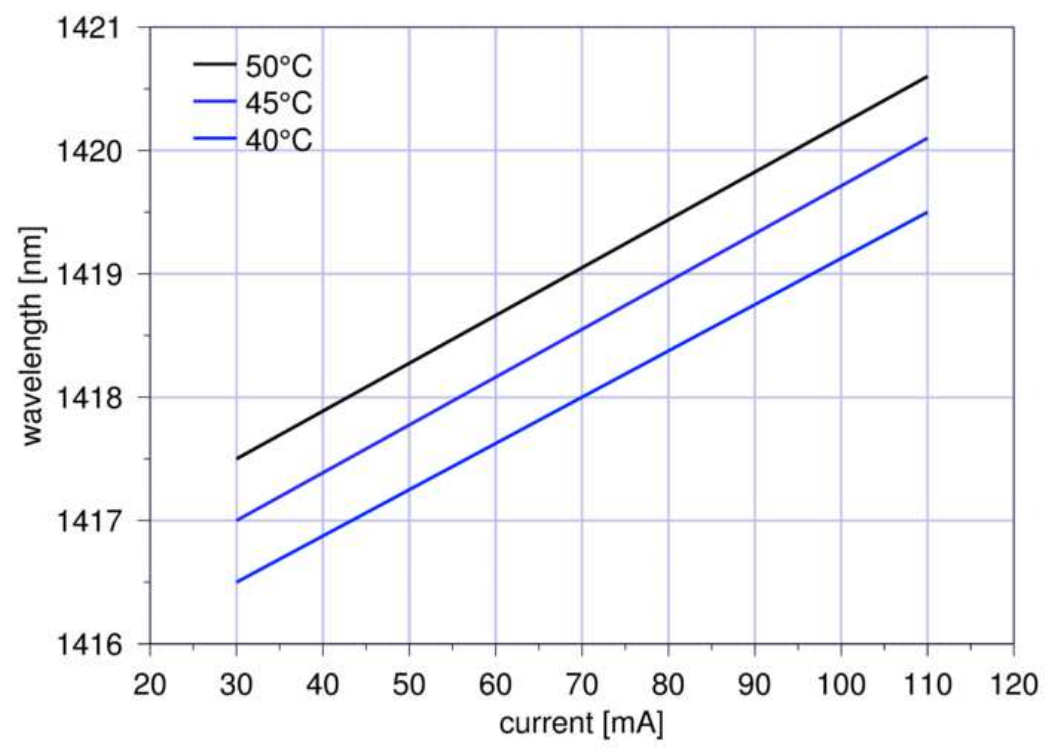

Ábra 3: Egy DFB diódalézer hangolhatósága. /current: áramerösség; wavelength: hullámhossz/ Kép forrása: [65].

\subsection{A spektrumvonalak alakja}

A vizsgálataim célja egy olyan abszorpciós spektroszkópián alapuló múszer tökéletesítése, amely mind a földfelszínen, mind pedig különböző repülési magasságokban képes pontos méréseket végezni. Ennek megfelelően a tervezéskor figyelembe kellett venni a különböző vonal-kiszélesedési és vonal-eltolódási mechanizmusokat [66]. Bár a repülési magasságban a levegő hőmérséklete akár $-70^{\circ} \mathrm{C}$ is lehet, de a PA kamra (3.7) sajátosságai miatt a mérendő gázt mindenképpen fel kell melegíteni $+45{ }^{\circ} \mathrm{C}-\mathrm{ra}$, azaz a mérörendszer tervezett üzemi hőmérsékletére. Így a vonalalak hőmérséklettől való függését nem kellett figyelembe venni sem a rendszer tervezése (8), sem pedig a kalibrációs mérések (7) során. A múszer tervezett múködési tartománya a 100-1000 mbar nyomástartományon belül van, ahol a nyomásfüggő vonalkiszélesedést és vonaleltolódást is figyelembe kell venni. Az ütközési vonalkiszélesedés klasszikus elmélete szerint az ütközési kiszélesedett vonal alakja Lorentz görbével írható le, amely a nyomás csökkenésével, folytonos átmenettel a Doppler kiszélesedést leíró Gauss görbévé alakul át. A folytonos átmenetet az úgynevezett Voigt profillal lehet közelíteni, ami egy Gauss és egy Lorentz görbe konvolúciójaként áll elő [66, 67].

Az ütközési vonalkiszélesedésre Lorenzt görbét eredményező klasszikus elmélet azonos tömegú és ellentétes sebességű, teljesen rugalmasan, centrálisan ütköző molekulákat tételez fel. A valóság ennél összetettebb; a vonalalak pontosabb leírását eredményező modellek [68- 
71] már figyelembe veszik az egyes molekulák egymáshoz viszonyított sebességét, a molekulák tömegét is. A modell ilyen módú megváltoztatása ugyan csak kismértékú korrekciót okoznak a vonalalakot közelítő függvényekben, de pl. DA-TDL mérések (3.5.3.2) esetén lényegesen kisebb illesztési hiba érhető el [71]. A múszer tervezett múködési tartománya a 0.5-40000 ppmV tartomány így nem lehet figyelmen hagyni azt a tényt, hogy a különböző koncentrációk esetén más-más valószínúséggel ütközik vízmolekula vízmolekulával, nem pedig a vivőgázként jelenlévő nitrogén vagy oxigénmolekulákkal. Ez a koncentrációfüggő valószínűség azt eredményezi, hogy a vonalalak nem csak a teljes nyomástól, hanem a vízgőz parciális nyomásától is függ.

\subsection{Vízgőz-koncentráció- mérő- müszerek}

A vízgőz-koncentráció- mérés talán első eszközei a hajszál higrométerek voltak, melyek az emberi haj relatív páratartalom függő rugalmassági tulajdonságain alapultak. A modern műszereknek számos változata ismert, ezek a teljességre való törekedés igénye nélkül:

- hútött szenzoros harmatpont-mérők

- kapacitív szenzorok

- spektroszkópiai elvű rendszerek

\subsubsection{Hütött szenzoros koncentrációmérők}

A hútött szenzoros koncentrációmérők a harmatpont közvetlen detektálásán alapulnak. Bennük egy változtatható hőmérsékletű kondenzációs felület hőmérsékletét arra a maximális hőmérsékletre állítják be, melynél a felületre víz kondenzálódik. Így a felület hőmérsékletét mérve meghatározható a harmatpont, amiből pedig a nyomás ismeretében az abszolút páratartalom és a koncentráció is. A felületre kondenzálódott víz detektálására két módszert használnak. A kiforrottabban és elterjedtebben használtban a kondenzációs felület egy tükör, aminek a reflexióváltozásából következtetnek a kondenzátum jelenlétére. Ezen műszerek az úgynevezett tükrös harmatpontmérők (Ábra 1). A másik, felfutóban lévő múszertípusban pedig egy felületi akusztikus hullám (SAW ${ }^{21}$ ) kristály egyik lapja a kondenzációs felület [72]. A kristály rezonanciafrekvenciájának a megváltozása jelzi a felületen megjelenő

\footnotetext{
${ }^{21}$ Surface Acoustic Wave
} 
kondenzátumot. A hőmérséklet pontos beállítására mindkét esetben PID $^{22}$ algoritmust szoktak alkalmazni.

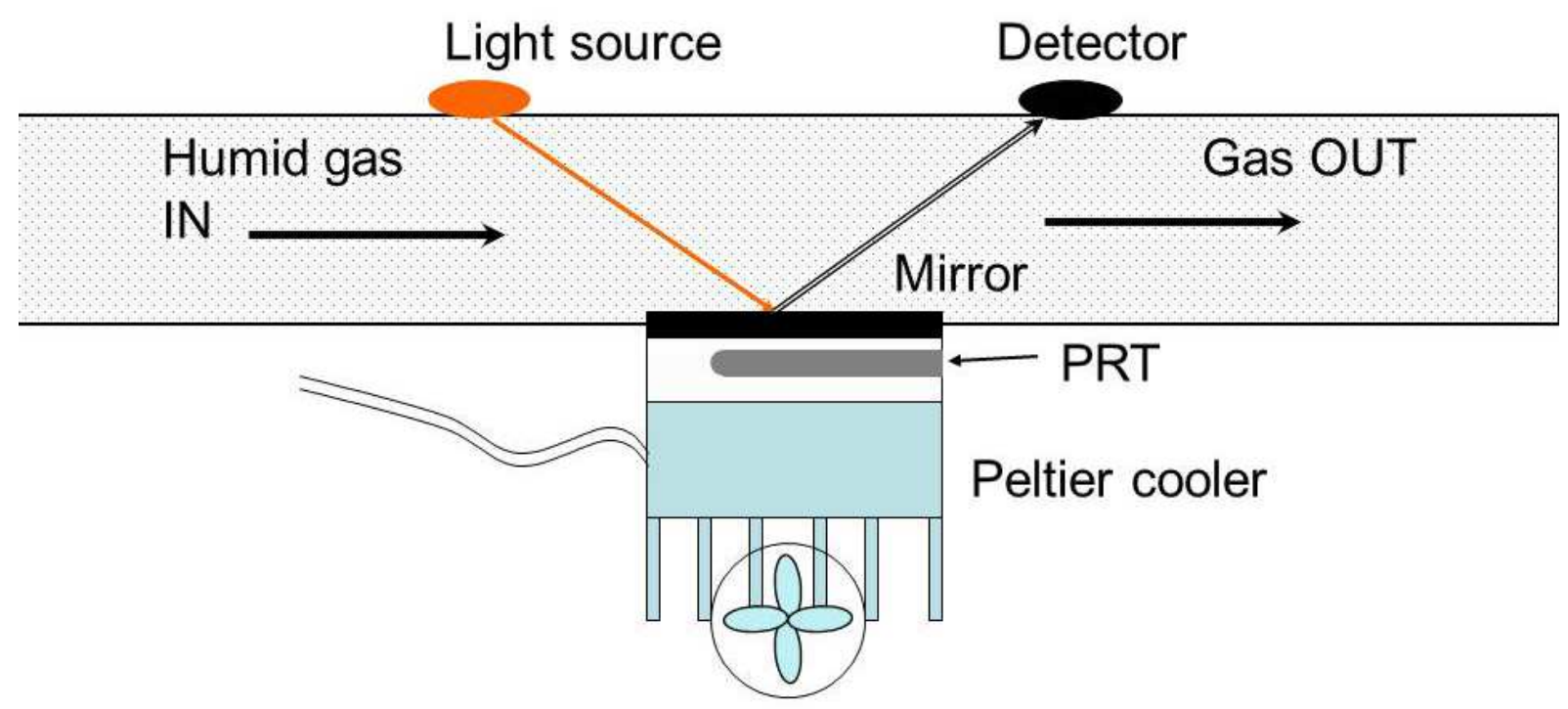

Ábra 4: Tükrös harmatpontmérö felépitése [73]. /light source: fényforrás; detector: detektor; humid gas in: nedves gáz bevezetése; gas out: gáz kivezetése; mirror: tükör; PRT (platina resistance thermometer): platina ellenállás hömérö; Peltier cooler: Peltier hütő/

Ezen szenzorok jellemző tulajdonsága, hogy jelentős integrálási idővel rendelkeznek, valamint hirtelen koncentrációváltozások esetén a kondenzációs felület hőmérsékletének beállítása során jelentős túllövések is előfordulhatnak. Ezek következtében e szenzorok repülőgépes mérések elvégzésére csak korlátozottan alkalmasak. Ugyanakkor a tükrös harmatpontmérők kiforrottságuk révén kiválóan alkalmasak laboratóriumi referenciaműszereknek.

\subsubsection{Kapacitív szenzorok}

A kapacitív szenzorokban egy kondenzátor fegyverzetei közé páratartalomtól függő deilektromos állandójú anyagot helyeznek el, így a kapacitás megváltozásából lehet következtetni a vízgőz-koncentrációra. A kapacitív szenzorok a relatív páratartalom mérésére alkalmasak így abszolút páratartalom meghatározásához szükség van a gáz pontos hőmérsékletének ismeretére is. Ezen szenzorok nagy előnye, hogy kis méretűek, olcsóak,

\footnotetext{
${ }^{22}$ Proportional Integral Derivative
} 
hátrányuk viszont, hogy kis koncentrációk és alacsony nyomások esetén korlátozott a megbízhatóságuk [74]. Ilyen szenzorokat alkalmaznak a MOZAIC projektben is [75].

\subsubsection{Spektroszkópiai elvű rendszerek}

A spektroszkópiai elvű mérőrendszereket két típusra lehet felosztani:

\subsubsection{Lyman- $\alpha$ lumineszcencia}

A Lyman- $\alpha$ lumineszcencia elvű műszerek a vízmolekulák fotodisszociációján alapulnak [33, 76, 77]. Bennük egy Lyman- $\alpha$ fényforrás segítségével elbontják a vízmolekulákat, majd a keletkezett ionok rekombinálódása során 309 nm-es hullámhosszúságú foton emittálódik. Ezen lumineszcencia intenzitása arányos a koncentrációval. Ezek a múszerek korábbi laboratóriumi [50] és repülőgépes [77] összehasonlító mérések alapján a legnagyobb pontosságúak és a legkisebb kimutatható koncentrációval rendelkezők közé tartoznak. Hátrányuk, hogy hozzávetőlegesen ezer ppmV koncentráció felett nem használhatóak, valamint, hogy jelenleg nincsen megfelelően stabil hordozható Lyman- $\alpha$ fényforrás, így ezek a múszerek rendszeres kalibrálásra szorulnak.

\subsubsection{Optikai abszorpció mérése}

Az optikai abszorpción alapuló koncentráció-meghatározásnak az alapját a Beer-Lambert törvény adja:

$$
P_{k i}(\lambda)=P_{b e}(\lambda) \cdot e^{-\alpha(\lambda) \cdot L \cdot c}
$$

ahol $\boldsymbol{P}_{\boldsymbol{k}}(\lambda)$ és $\boldsymbol{P}_{b e}(\lambda)$ a minta utáni és előtti fényteljesítmény $(W), \alpha(\lambda)$ a hullámhosszfüggő abszorpciós együttható $\left(\mathrm{ppmV}^{-1} \mathrm{~m}^{-1}\right), L$ a fény által a mintában megtett úthossz $(\mathrm{m}), \boldsymbol{c}$ a koncentráció (ppmV). Számos elterjedt eljárás alapul az optikai abszorpció mérésén [78], ezek közül néhányat emelnék ki:

- DA-TDL (Direct Absorption Tuneable Diode Laser) spektroszkópia

- $\quad 2 f$ spektroszkópia

- CRD (Cavity RingDown) spektroszkópia

- OA-ICOS (Off-Axis Integrated Cavity Output Spectroscopy)

- PA spektroszkópia 
A DA-TDL spektroszkópia alkalmazása során a vizsgált gázt egy olyan hangolható diódalézerrel világítják át, amelynek a hangolási tartományán belül van a vizsgált komponensnek legalább egy elnyelési vonala. A mérések során a lézert áthangolják az elnyelési vonalon, közben pedig egy megfelelő fotodióda segítségével mérik a mintán átjutó fényintenzitást. A hangolás során rögzített fotodióda időjelből, a nyomásból és a hőmérsékletből a vonalalak valamint az úthossz ismeretében vonalprofil illesztéssel meghatározható a koncentráció [79-81]. A DA-TDL rendszerek dinamikus tartományát az alkalmazott fotodióda és a hozzá kapcsolt analóg-digitál (A/D) átalakító dinamikus tartománya limitálja tipikusan 3-4 nagyságrendben [82]. A legkisebb kimutatható koncentrációt a vonalerősség és az optikai úthossz szorzata limitálja. Herriott cellák alkalmazásával kis méretben is több száz méteres, kilométeres optikai úthosszat [83] el lehet érni, ekkor viszont a rendszer mechanikai stabilitása válik kérdésessé.

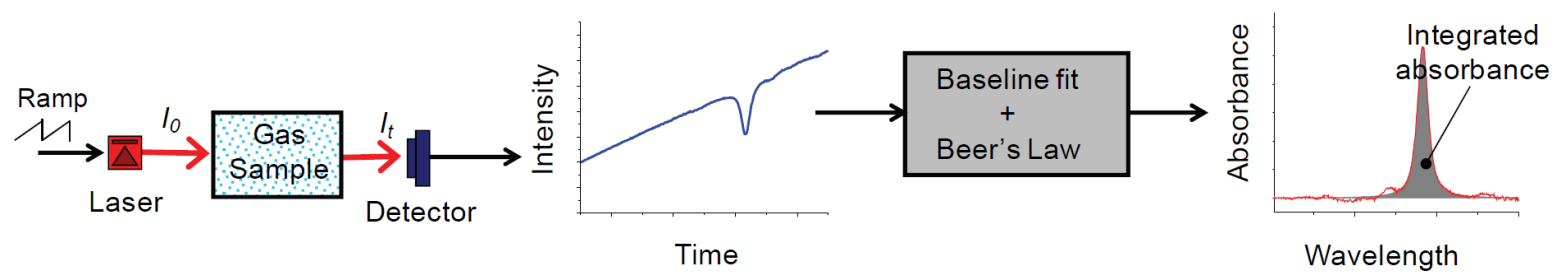

Ábra 5: A DA-TDL spektroszkópia elrendezése és müködési elve [80]. /ramp: fürészfogjel, laser: lézer, gas sample: gázminta, detector: detektor, intensity: intenzitás, time: idő, baseline fit: alapvonal illesztés, Beer's law: Lambert-Beer törvény, absorbance: abszorbancia, wavelength: hullámhossz, integrated absorbance: integrált abszorbancia/

A 2 spektroszkópia [84] alapja, hogy amennyiben egy szinuszosan hullámhossz-modulált lézer központi hullámhosszát egy elnyelési vonal csúcsára állítjuk be, akkor a moduláció frekvenciájának kétszeresén jelenik meg az abszorpcióhoz tartozó jel. A DA-TDL módszerhez képest nagy előnye, hogy az abszorpció mértéke így kétszeres frekvenciájú lock-in erősítővel mérhető. A lock-in technika alkalmazhatóságának következtében azonos mértékű abszorpció esetén lényegesen nagyobb jel/zaj aránnyal lehet méréseket végezni. A módszernek két hátránya van: a lézer modulációs tulajdonságai miatt fényútban lévő elnyelő komponensek nélkül is van mérhető $2 f$ jel, azaz a mérés nem nulla hátterű, valamint a TDL módszerhez képest egy-másfél nagyságrenddel stabilabb lézervezérlésre van szükség alkalmazásához [85]. Egy érdekes technikai megoldás a DA-TDL és a 2 f technika egy rendszerben való megvalósítása, mely a két technika előnyeit tudja kombinálni [86]. 
A CRD [87] technológiában a vizsgálandó mintát egy stabil, nagy jósági tényezőjű optikai rezonátorba vezetik be. A rezonátor egyik tükrén keresztül az alkalmazott lézer fényét bevezetik a rezonátorba. Ekkor a lézer bekapcsolását követően a rezonátor másik tükrén keresztül kiszivárgó fény intenzitását mérve abban növekedést lehet tapasztalni. $A z$ intenzitásban egy küszöbérték elérése után a lézert ki kell kapcsolni. Ekkor a mérhető intenzitás a tükrökön való veszteségek és az optikai abszorpció miatt exponenciálisan lecseng. A lecsengési időből a zérus abszorpcióhoz tartozó lecsengési idő, valamint a mérendő komponens abszorpciós együtthatójának ismeretében meghatározható a koncentráció. Ezzel az eljárással a rezonátorban kialakuló hatalmas fényút miatt nagy érzékenységgel lehet kis abszorpciókat is mérni. A módszernek két fő hátránya van, ezek:

- Egy, extrém kis koncentrációk mérésére optimalizált rendszer mechanikailag igen kevéssé ellenálló, a legkisebb rezgések, hőtágulás következtében jelentősen megváltozik az érzékenysége.

- A tükrök kismértékű szennyeződése is jelentősen rontja a rendszer működését.

Fontos megjegyezni, hogy a CRD rendszerek optikai rezonátora egy nagy jósági tényezőjü Fabri-Perot rezonátor, így folytonos üzemú lézereket használva csak diszkrét hullámhosszakon lehet vele méréseket végezni.
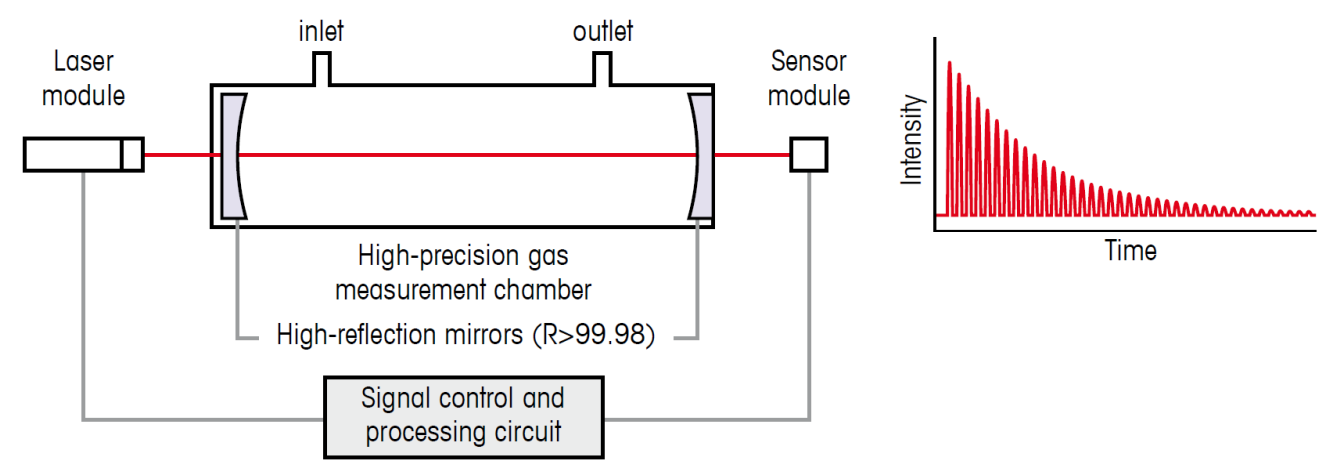

Ábra 6: Impulzus CRDS kísérleti elrendezés és a mérhető nyers jel [81]. /laser module: lézermodul, inlet: bevezetés; outlet: kivezetés, sensor module: szenzormodul, high precision gas measurement chamber: nagy precizitású gázvizsgáló kamra, high-reflection mirrors: magas reflexiójú tükrök, signal control and processing unit jelkeltő és feldolgozó egység, intensity: intenzitás, time: idő/ 
Az OA_ICOS technológia [88] a CRD továbbfejlesztéseként jött létre, amelyben off-axis világítanak be egy két tükörből álló optikai rezonátorba, melyben az egyik tükör megdöntésével kismértékű asztigmiát vezetnek be. A rezonátor megfelelő tervezésével mechanikailag stabil módon el lehet érni, hogy a rezonátorbeli lézernyaláb akár több kilométer megtétele után se interferáljon önmagával. Azaz azt, hogy az alkalmazott optikai rezonátor ne viselkedjen Fabri-Perot interferométerként. Ennek köszönhetően az OA-ICOS rendszerek érzékenysége a CRD rendszerekével azonos vagy jobb, viszont a DA-TDL rendszerek megbízhatóságával bírnak.

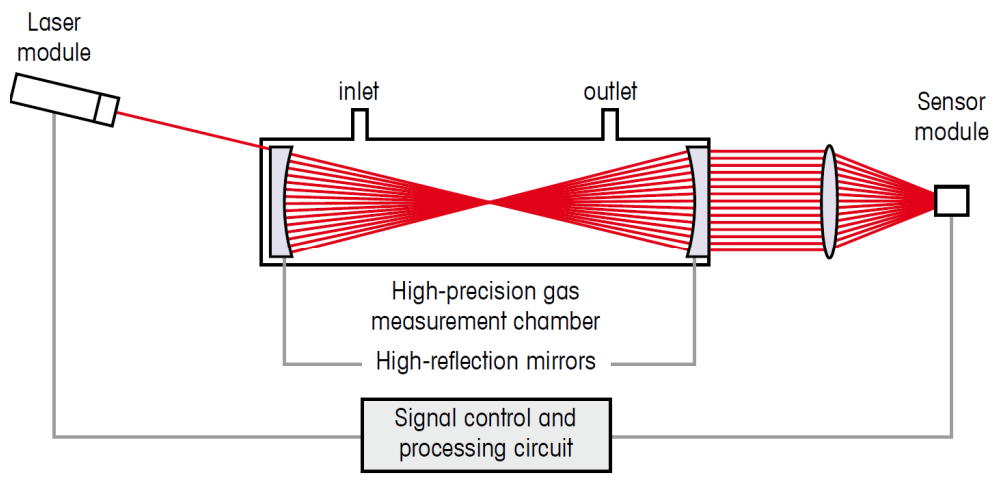

Ábra 7: OA-ICOS kísérleti elrendezés [81]. /laser module: lézermodul, inlet: bevezetés; outlet: kivezetés, sensor module: szenzormodul, high precision gas measurement chamber: nagy precizitású gázvizsgáló kamra, high-reflection mirrors: magas reflexiójú tükrök, signal control and processing unit jelkeltő és feldolgozó egység/

Napjainkban a PA spektroszkópia, -melyet a 3.6 fejezetben ismertetek részletesebben - az egyik legígéretesebb technikai megoldásnak tűnik a repülőgépes vízgőzmérés területén köszönhetően megfelelő érzékenységének, több mint 6 nagyságrendbeli dinamikus tartományának és egyszerű optikai felépítése révén kivételes mechanikai stabilitásának. Legjobb tudomásom szerint a Szegedi Tudományegyetemen és a vele együttműködő Hilase Kft-n [21] kívül máshol nem foglalkoznak repülőgépre telepíthető PA elvű vízgőz-koncentrációmérő műszer fejlesztésével. Ugyanakkor a Droplet Measurement Technologies, Inc (Boulder, USA) kétféle repülőgépre telepíthető PA spektroszkópián alapuló aeroszol koncentráció mérő műszert is kifejlesztett [89].

\subsection{A fotoakusztikus spektroszkópia alapjai.}

A PA spektroszkópia alapját a Bell által felfedezett PA effektus [90, 91] adja. Az effektussal kapcsolatos további gondolatmenetet gázban történő PA jelkeltésre szúkítettem, de a 
megállapítások jelentős része igaz folyadék és szilárdtest PA spektroszkópia esetén is. Modulált fényelnyelés hatására sugárzásmentes relaxáció esetén az elnyelt fényenergia hővezetés, hődiffúzió révén részben akusztikus energiává alakul. A keletkező akusztikus jel intenzitása általában igen kicsiny ezért azt egy úgynevezett PA kamrában kialakított akusztikus rezonátorban célszerű erősíteni detektálás előtt. A rezonátorban felerősített akusztikus jelet egy érzékeny mikrofonnal lehet detektálni. A modern méréstechnikában egy mikrofon jelének a detektálása egyet jelent egy kiszajú erősítővel való jelkondicionálás utáni digitalizálással. A továbbiakban a mikrofonnal detektált és erősített jelet nevezem mikrofonjelnek. A továbbiakban a digitalizált mikrofonjelet fotoakusztikus időjelként fogom említeni. A jelfeldolgozás során, mint látni fogjuk, a mikrofonjelnek a moduláció alapharmonikusához tartozó intenzitását kell meghatározni, így természetes módon adódik a lock-in detektálási technika. A továbbiakban a PA időjelből számolható, a modulációs frekvenciához tartozó lockin értéket nevezem fotoakusztikus jelnek. A PA jel arányos az elnyelt fényteljesítménnyel, azaz gyenge elnyelés esetén, - ha a Lambert-Beer törvény Taylor sorfejtésének lineáris tagjával közelíthető, - akkor az elnyelő komponens(ek) koncentrációjával is [92]:

$$
P A=P \cdot M \cdot C \cdot \alpha \cdot c,
$$

ahol $\boldsymbol{P}$ a fényforrás teljesítménye (W), $\boldsymbol{M}$ a mikrofon érzékenysége $(\mathrm{V} / \mathrm{Pa}), \boldsymbol{C}$ a kamrakonstans $(\mathrm{Pa} \times \mathrm{m} / \mathrm{W}), \alpha$ az abszorpciós együttható $\left(\mathrm{ppm}^{-1} \times \mathrm{m}^{-1}\right), c$ pedig a koncentráció (ppm).

A PA jelkeltés elméleti leírásának egyik eleme [93, 94], hogy a keltett akusztikus jel, tehát a PA időjel is az elnyelt fényteljesítmény $\left(\boldsymbol{P}_{a b s}\right) A C^{23}$ komponensével arányos. Ennek megfelelően, a Fourier transzformáció deriválási szabályának értelmében a PA időjel egy $90^{\circ}$-os fázistolást leszámítva arányos az elnyelt fényteljesítmény idő szerinti első deriváltjával.

$$
P A(t) \sim \frac{d P_{a b s}}{d t}
$$

$\mathrm{Az}$ elnyelt fényteljesítmény modulációját a fényforrás teljesítményének, vagy pedig az abszorpciós együttható megváltoztatásával lehet előidézni. Diódalézeres fotoakusztika esetén a 2-3 egyenletek értelmében a lézerre adott áramerősség modulálásával el lehet érni, hogy a

\footnotetext{
${ }^{23}$ Alternating Current
} 
lézernek periodikusan változzon mind a teljesítménye, mind pedig a hullámhossza. A lézer teljesítményének a megváltoztatásával, megfelelő múködési hullámhossz(ak) mellett triviális módon el lehet érni az elnyelt fényteljesítmény modulációját. A hullámhossz-moduláció mértékének és a központi hullámhossz (alkalmazástól függően történő) megfelelő beállítása esetén, elsősorban keskeny elnyelési vonalak esetén el lehet érni, hogy a lézer hullámhossza periodikusan változzon az elnyelési vonal csúcsa és az elnyelési vonal valamely széle között, tehát a lézer hullámhosszához tartozó abszorpciós együtthatót lehet változtatni. A 2-3 egyenletekből következik, hogy az áramerősség modulációjával nem érhető el tisztán sem a teljesítmény, sem pedig a hullámhossz modulációja. Mégis szokás mind amplitúdó, mind pedig hullámhossz-modulációról beszélni: Diódalézerek árammodulálása esetén hullámhosszmodulációról beszélünk, amennyiben a keltett PA jelben a lézer teljesítményének megváltozása okozta változás az elnyelt fényteljesítményben elhanyagolható a hullámhosszváltozás okozatához képest. Amplitúdó-modulálásról pedig fordított esetben beszélünk. E két szélsőséges esetet egy folytonos átmenet köti össze. Egy keskeny elnyelési vonal esetén általában a hullámhossz-modulációhoz közeli tartományban található egy olyan modulációs mélység, amelynél maximális a keltett PA jel, ekkor maximális a mérőrendszer érzékenysége. Ezt az optimális modulációs mélységet minden egyes alkalmazás esetén kísérleti úton kell meghatározni [95]. A hullámhossz-moduláción alapuló diódalézeres PA spektroszkópiát számos tanulmányban mutatták már be részleteiben [96-98].

\subsection{Egy általános célú fotoakusztikus spektroszkópiai rendszer felépítése}

Egy általános PA spektroszkópiai berendezés hat fő egységből áll [98] (Ábra 8):

1. fényforrás és vezérlője

2. PA kamra

3. mikrofonerösítő

4. lock-in erősítő

5. gázkezelés

6. adatrögzítő egység 


\section{vezérlőelektronika}

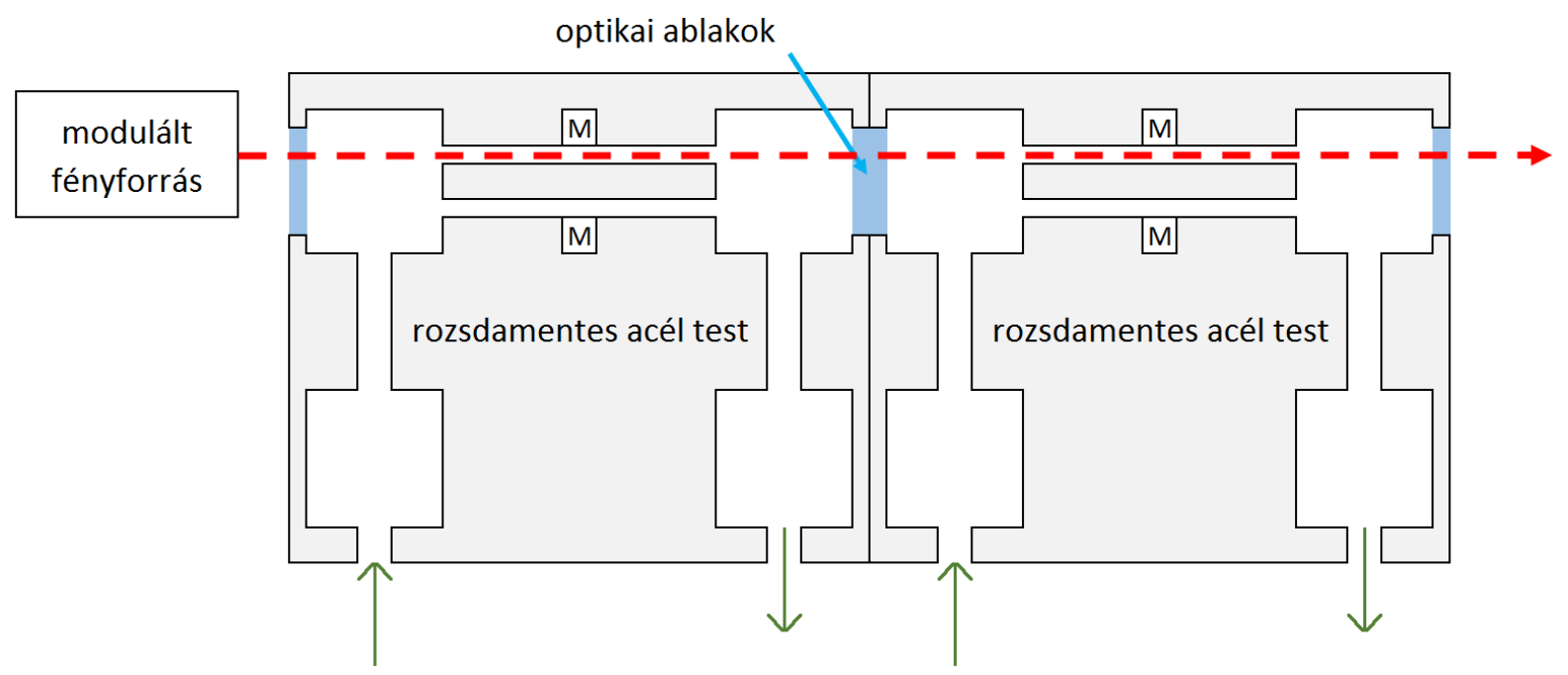

Ábra 8: Egy általános kétcsatornás PA mérörendszer felépitése. A zöld nyilak a gázáramlás irányát, $M$ a mikrofonokat jelöli. A vezérlöelektronika integráltan tartalmazza a fényforrás vezérlőjét, a mikrofonok erősitőjét, lock-in erősitőt és adatrögzítőt.

\section{Fényforrás}

A PA spektroszkópiában általában lézereket vagy lézerszerü fényforrásokat $\left(\mathrm{OPO}^{24}\right)$ használnak fényforrásként, de foglalkoznak színszürökkel kombinált feketetest sugárzók használatával is [99]. A fényforrással szemben támasztott legfőbb követelmény, hogy olyan hullámhosszon világítson, vagy a hangolási tartományában legyen olyan hullámhossz, amelyen a vizsgálni/kimutatni kívánt anyagnak van elnyelése. Ezen felül előnyös, ha elektronikusan modulálható, nagy fényteljesítményü, hosszú távon stabilan és megbízhatóan működik, valamint optikai szálba csatolt. Ezen kitételeknek, az optikai szálba való csatoltságot leszámítva megfelelő DFB diódalézer gyakorlatilag minden vibrációs átmenettel rendelkező molekula esetén található $[56,100]$.

\section{Fotoakusztikus kamra}

A PA kamrának [101-104] alapvetően három feladata van:

- Benne történik az akusztikus jel keltése és passzív erősítése, valamint a kamrába integrált mikrofonnal való detektálása.

${ }^{24}$ Optikai Parametrikus Oszcillátor 
- Feladata —megfelelő kialakítása révén—a külső akusztikus zajok kiszürése.

- Feladata továbbá, hogy a vizsgálandó gázt izolálja a külvilágtól, hogy az esetleges keveredések, szivárgások ne befolyásolják a vizsgálatokat.

Egy általunk használt PA kamrában az optikai úthossz mindössze 8-10 cm, így nagyobb koncentrációk esetén is kismértékủ benne a fényintenzitás csökkenése, ezért a kamra ablakán kilépő maradék fényt be lehet vezetni egy második, szükség szerint akár harmadik-negyedik kamrába is (Ábra 8). Ezáltal válik lehetővé egyszerű felépítés mellett a kétcsatornás működés. A mérőkamra tartalmazhat egy vagy két egyforma akusztikus rezonátort. Két rezonátor esetén csak az egyiken világítunk át a fényforrással, így csak abban keletkezik PA jel; az ebben elhelyezett mikrofonnal a PA effektus révén keltett akusztikus jelet, valamint zajokat detektálunk, míg a másik rezonátorban elhelyezett mikrofonnal csak zajokat. A két mikrofon jelének a különbségét analóg technikával képezve lényegileg zajmentes méréseket lehet elvégezni. A kétrezonátoros kamrákat müködési elvük alapján differenciálisnak is szokás nevezni A mérőkamrák hőmérsékletét stabilizálni kell, hogy a rezonanciagörbéjük ne tolódjon el a hőmérséklet-változás okozta hangsebesség-változás miatt.

\section{Mikrofonerősítő}

A mikrofonerősítő feladata a detektorként használt mikrofon jelének kondicionálása, feldolgozható mértékűre való erősítése.

\section{Lock-in erősítő}

A lock-in erősítő feladata akár analóg, akár digitális formában a PA jel nagyságának és fázisának meghatározása a mikrofonjelből.

\section{Gázkezelés}

Egy specializált mérőrendszerben szükséges a megfelelő áramlási sebesség, a megfelelő nyomás, hőmérséklet beállítása, valamint különböző mérésmódok, mintavételezési helyek közötti váltás. Ezt tömegáramlás-szabályozókkal, mágnesszelepekkel... lehet megvalósítani

\section{Adatrögzítő}

Adatrögzítés céljából általában ipari számítógépeket, beágyazott rendszereket szokás használni, melyek vagy valamilyen interfészen (Eternet, Ethercat, Modbus, Profibus, USB, RS232, RS485, GPIB...) keresztül egy központi számítógépre továbbítják a mért adatokat, vagy közvetlenül valamilyen hordozható adathordozóra mentik azokat. 


\subsection{A Szegedi Tudományegyetem és a Videoton Holding Zrt. együttmúködésében kifejlesztett mérésvezérlő elektronika}

Egy mérőrendszer gyakorlati alkalmazhatóságát jelentős mértékben javítja, ha az egyes funkciókat ellátó elektromos egységek nem önálló eszközök, hanem egy központi beágyazott rendszer köré épített egységes rendszer. E szempont figyelembevételével a Szegedi Tudományegyetemen múködő Fotoakusztikus Spektroszkópiai Kutatócsoport részére a Videoton Holding Zrt. fejlesztési osztályán kifejlesztettek egy PA mérések elvégzésére szolgáló programozható mérésvezérlő és adatgyújtő rendszert (a továbbiakban VT elektronika).

A VT elektronika egy DSP25 alapú, részben felhasználók által programozható rendszer, mely (többek között) tartalmaz dióda lézer meghajtót, dióda lézer hőmérsékletstabilizálót, mikrofonerősitőket egyenként dedikált digitális lock-in erősítóvel, analóg és digitális ki és bemeneteket, PT100 hőmérő bemeneteket és egy kommunikációs portot (Modbus, RS232 vagy RS485 opcionálisan beállítható).

Az analóg bemeneteket különböző, 0-5 V-os jelt adó szenzorok pl. nyomásmérők jelének mérésére, az analóg kimeneteket (0-5 V) pl. áramlásszabályzók vezérlésére lehet felhasználni. A digitális kimenetekkel kétállású eszközöket, mint pl. mágnesszelepeket vagy reléket lehet vezérelni, míg a digitális bemeneteken keresztül - megfelelő programozás esetén - akár mérőrendszer állapotát is meglehet változatni.

\subsection{A Szegedi Tudományegyetemen fejlesztett repülőgépre telepíthető vízgőzmérők fejlesztése}

A CARIBIC projekt indulásakor Szegedi Tudományegyetem Optikai és Kvantumelektronikai Tanszékén múködő Fotoakusztikus Spektroszkópiai Kutatócsoportot Dr. Andreas Zahn (CARIBIC projekt, FZK, KIT) felkérte, hogy a projektben való alkalmazáshoz fejlesszen ki egy repülőgépre telepíthető vízgőz- és teljes víz tartalom- mérő- múszert. A műszerrel szemben elvárás volt, hogy:

\footnotetext{
${ }^{25}$ Digital Signal Processor
} 
- legyen precíz minden nyomáson tetszőleges koncentráció mellett, ami előfordulhat egy repülés alatt: 180-1050 mbar (légnyomás repülési magasságban és talajszinten) és 1-40000 ppmV (extrém száraz levegő repülési magasságban és extrém nedves levegő talajszinten),

- legyen rövid válaszidejü,

- legyen kis méretű és tömegú,

- állandó felügyelet nélkül teljesen automatizáltan működjön,

- ne igényeljen rendszeres kalibrálást, karbantartást,

- legyen ellenálló rázkódásokkal, környezeti zajokkal szemben,

- feleljen meg az igen szigorú biztonsági előírásoknak.

A vízgőz-koncentráció és a teljes víz tartalom méréséhez a múszernek két csatornával kell rendelkeznie, melyeket a repülőgép alján elhelyezett mintavevőkhöz csatlakoztatnak. A mintavevő leegyszerűsítve a repülési irányhoz viszonyítva egy előre és egy hátrafelé néző csőből áll (Ábra 9). A hátrafelé néző csövön keresztül egy pumpa segítségével kell beszívni a levegőt, míg az előrenéző esetében a torlónyomás is elegendő lehet. A hátrafelé néző mintavevővel értelemszerúen csak gázfázist lehet mintavételezni, tehát arra van a PA múszer első, azaz vízgőz kamrája csatlakoztatva. Az előre néző az útjába kerülő vízcseppeket és jégkristályokat is, azaz a légkör teljes víz tartalmát gyújti be. A nem gáz fázisú víz részben a torlónyomás okozta adiabatikus kompresszió, részben pedig a csövek fútése következtében elpárolog, így vízgőzként lesz detektálható a teljes víz tartalom is. Ez utóbbi mintavevő van a PA rendszer teljes víz, azaz második mérőkamrájára kötve. Ezzel az elrendezéssel a két mérőkamrában mérhető koncentrációk különbsége a felhők víztartalmát adja. 


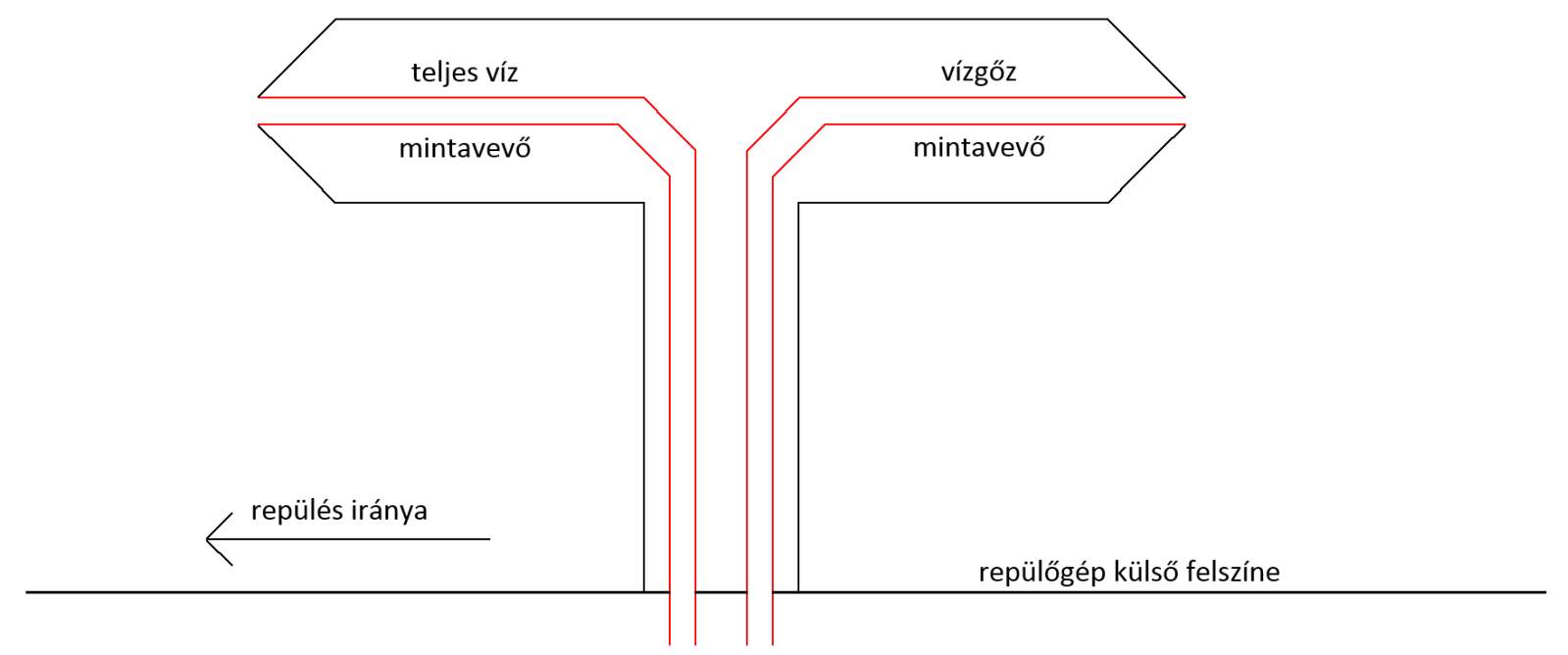

Ábra 9: Egy általános célú repülőgépes mintavevő vázlata. A repülési irányába néző mintavevővel a légkör teljes víz tartalmát, míg a hátrafelé nézővel csak a gázfázisú nedvességtartalmat lehet mintavételezni.

Szakáll Miklós doktori munkájaként kezdte el ennek a rendszernek a fejlesztését. A témában két alapvető fontosságú publikációt $[95,105]$ jegyez, valamint doktori értekezésében [106] is a témában elért eredményeit ismertette. Az általa elvégzett kutatómunka eredményei olyannyira alapvető fontosságúak, hogy kutatócsoportban egy-egy új alkalmazás tervezésekor ma már természetesnek vesszük azok használatát. Ilyenek például a PA kamra hőmérsékletstabilizálásának a fontossága, vagy például az alkalmazott DFB diódalézerek hőmérsékletének stabilizálására kidolgozott kétszeres stabilizálási séma. Szakáll Miklós munkájának eredményeként a Szegedi Tudományegyetem is részese lett a CARIBIC projektnek, de ami talán fontosabb, hogy nagy mértékben sikerült javítania a szegedi PA rendszerek pontosságát, megbízhatóságát. A CARIBIC projekthez készített rendszer, a továbbiakban CARIBIC1 rendszer egy 1371 nm hullámhossz körül hangolható DFB diódalézerből, három PA kamrából és egy vezérlőelektronikából állt. Az első kamra a vízgőz, a második pedig a teljes víz mintavevőre volt csatlakoztatva, a harmadik kamra pedig referenciaként került a rendszerbe, állandóan le van zárva. Fontos megjegyezni, hogy a műszerrel szemben nem volt elvárás a koncentrációk meghatározása, mindössze nyers PA jelet kellett szolgáltatnia. A koncentráció meghatározásához Dr. Zahn a műszer rack-be beépített egy tükrös harmatpontmérő műszert, aminek a segítségével folyamatosan kalibrálja a PA rendszert [18]. A mostani tapasztalataim alapján kijelenthetem, hogy a rendszer vezérlőelektronikája koncentráció meghatározásra alapvetően nem is lett volna alkalmas; azt legfeljebb utólagos kiértékeléshez biztosított adatfeldolgozó programmal lehetett volna megoldani. 
2006-ban a VIDEOTON Zrt. Fejlesztési Osztályán készítettek egy új, könnyebben programozható elektronikát, mely számos extra lehetőséget kínált az előzőhöz képest. Az új vezérlőelektronikára alapozva elkészült egy önálló működésre, valós idejű koncentrációszámolásra tervezett rendszer is, melyre a továbbiakban SZTE1 rendszerként fogok hivatkozni. Ez a rendszer lett tesztelve a már említett AquaVIT kampány során [50-52]. Az eredmények azt mutatták, hogy a koncentrációszámolással és a rendszer kalibrálásával komoly problémák voltak (Ábra 10, Ábra 11). Ugyanez a rendszer részt vett egy repülőgépes mérési kampányban (2007, Koblenz, Németország), ahol repülés során lényegében csak zajt lehetett vele mérni.

Erre az elektronikára alapozva elkészült a CARIBIC1 rendszer frissítése, melyre a továbbiakban CARIBIC2 rendszerként fogok hivatkozni. Ezt a rendszert hosszas és eredményes laboratóriumi tesztelést követően Dr. Zahn egy teljesen új rackbe építette be. Felépítésére nézve ez az új rack alapvetően megegyezett az előzővel, ez is tartalmaz egy tükrös harmatpontmérőt (CR2, Buck Research Instruments, LLC). Ennek a rendszernek a repülés során való éles tesztelésére 2010-ben került sor és sajnálatos módon teljes kudarccal végződött. A rendszer a repülés alatt a 2007-es koblenzi mérésekhez hasonlóan zajon kívül nem mért semmilyen használható adatot.

Ezen igen komoly, a rendszer önálló műszerként való alkalmazhatóságát alapvetően korlátozó problémák mellett a Szakáll Miklós által kidolgozott, lézerek hullámhosszának pontos beállítására szolgáló eljárásról [105], kiderült, hogy igen jelentős a bizonytalansága ezért az további fejlesztésekre szorul. 


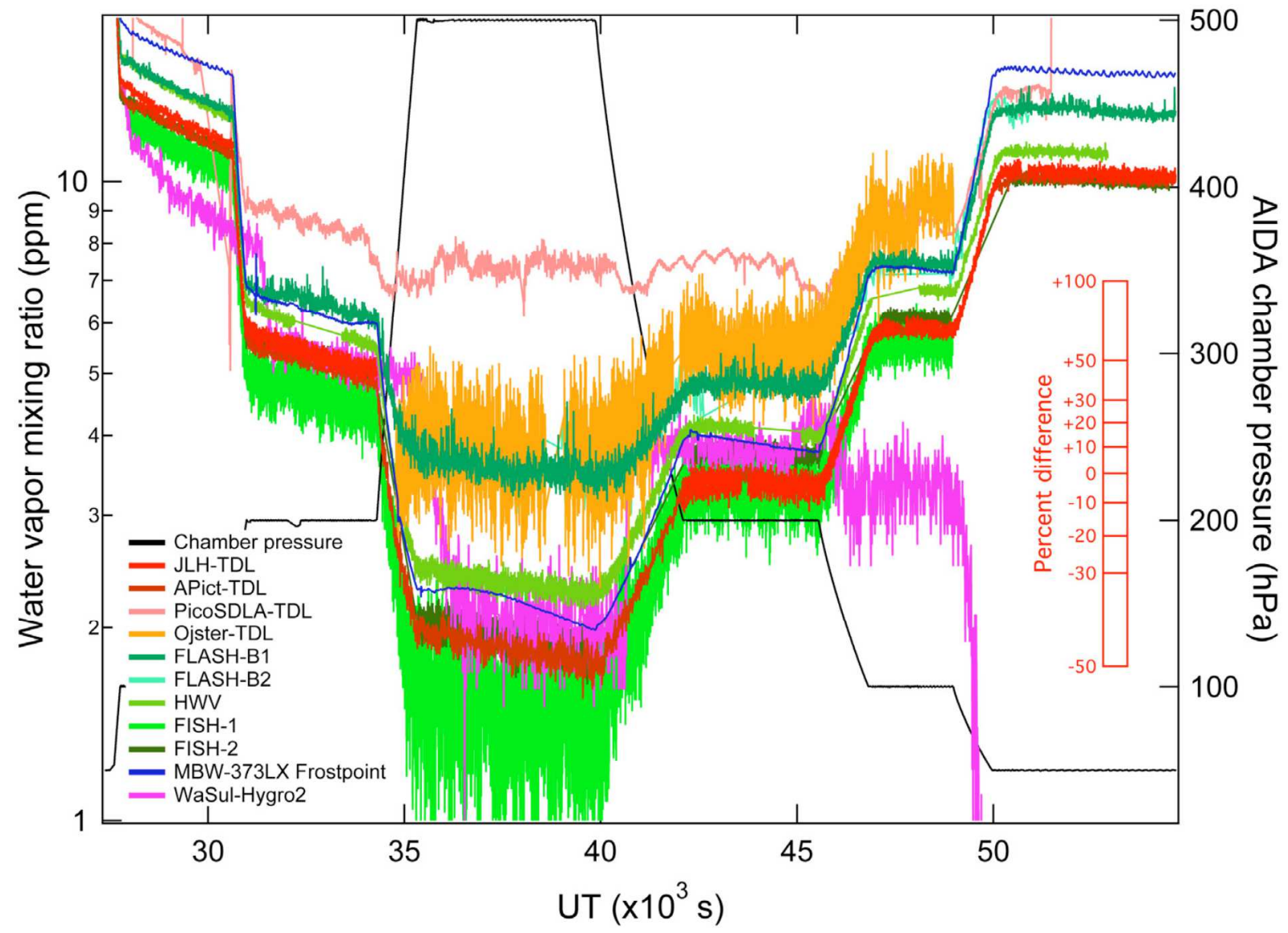

Ábra 10: Egy mérés összehasonlító eredményei az AquaVIT mérési kampányról [52]. WaSulHygro2-ként szerepel az SZTE1 rendszer. Jól látható az inkonzisztens müködés, amit lehet, hogy a nyomásfüggés nem megfelelö korrekciója okozott. /water vapor mixing ratio (ppm): vízgőz keverési arány (ppm), AIDA chamber pressure (hPa): AIDA kamra nyomása (hPa), UT: idő / 
AquaVIT Non-Core Instrument Accuracy: WaSul-Hygro2 Photoacoustic

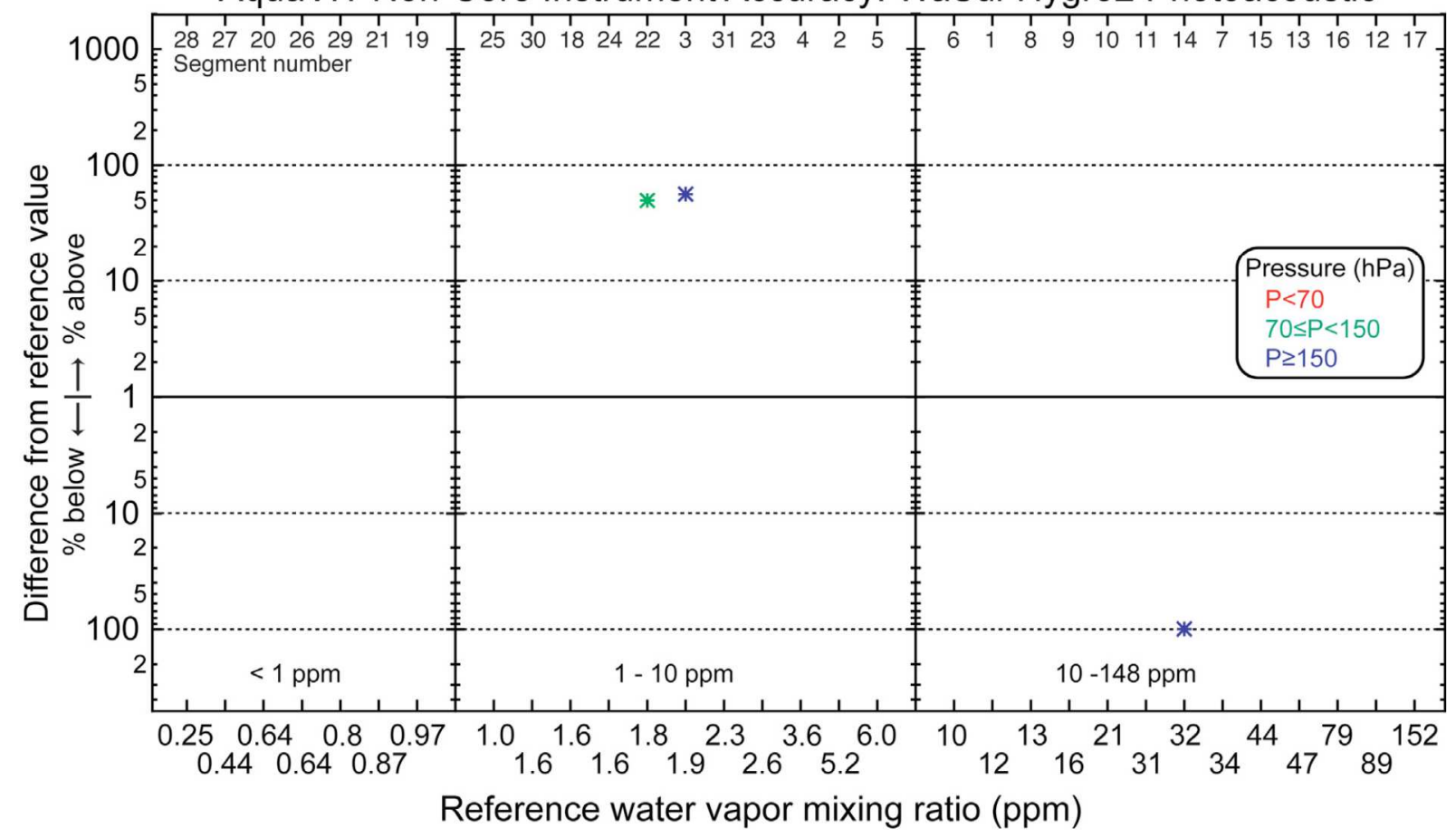

Ábra 11: A kutatócsoport által fejlesztett müszerrel az AquaVTT mérési kampányon mért eredmények összefoglalása [52]. 50 és 100\% körüli relatív eltérésekkel az eredmények igen rossznak nevezhetöek. /AauaVIT Non-CORE Instrument Accuracy: WaSul-Hygro2 Photoacoustic: Wasul-Hygro2 PA müszer pontossága az AquaVIT kampány során, difference from reference value: eltérés a referencia-értéktöl, below: kisebb, above: nagyobb, reference water vapor mixing ratio (ppm): referencia vízgőz keverési arány (ppm), pressure (hPa):

nyomás (hPa)/ 


\section{Célkitűzések}

Doktori munkám elején az alábbi célkitűzést fogalmaztam meg:

Célom, hogy Szegedi Tudományegyetemen fejlesztett repülőgépre telepíthető kétcsatornás PA elvű nedvességmérő-múszer megbízhatóságát, pontosságát javítsam a teljes múködési tartományában (azaz a 100-1000 mbar légköri nyomás és a 1-40000 ppmV vízgőzkoncentráció- tartományban); hogy a múszert alkalmassá tegyem az önálló, teljes mértékben automatizált múködésre; valamint a műszer méretét és tömegét számottevő mértékben csökkentsem, ezáltal is elősegítve gyakorlati alkalmazhatóságát, elfogadottságát.

Ezt a célkitűzést az alábbi feladatok megvalósításán keresztül terveztem elérni:

1. A mérőrendszer korábbi alkalmazásai során tapasztalt, a rendszer alkalmazhatóságát korlátozó zajok, instabilitások forrásainak felderítése, elemzése, kiküszöbölése.

2. A mérőrendszerben alkalmazott DFB diódalézer hullámhossz-beállítási pontosságának növelése, olyan mértékben, hogy a hullámhossz bizonytalansága a még a repülőgépek utazási magasságán fellépő, az alacsony légnyomásból származó keskeny abszorpciós vonalakon történő mérések során se okozzon mérhető bizonytalanságot a PA jelben, azaz a mért koncentrációban. Tézis 1

3. Olyan kalibrációs, jelkiértékelési és koncentráció-számolási eljárások fejlesztése a kétcsatornás PA vízgőzmérő rendszerhez, melyek segítségével biztosítható, hogy a repülések során előforduló teljes koncentráció és nyomás tartományban a műszer által mért és a kalibráló referencia eszköz által beállított koncentrációk között ne lépjen fel szisztematikus (azaz nem a mérések zajából származó) különbség. Tézis 2

4. A szerzett tapasztalatokra és az elvégzett fejlesztésekre alapozva egy új - elsősorban kutató-repülőgépeken alkalmazható - mérőrendszer (SZTE2 rendszer) építése, megbízhatóságának igazolása mind laboratóriumi, mind pedig repülőgépes összehasonlító mérések során. Tézis 3

5. A mérőrendszer majdani, utasszállító repülőgépekre is telepíthető változatának megalapozásához egy új, továbbcsökkentett méretű és tömegű mérésvezérlő és adatgyűjtő elektronika elkészítése. Tézis 4, Tézis 5

6. A Szegedi Tudományegyetemen kifejlesztett különböző repülőgépes vízgőzmérő rendszerek múködési paramétereinek szisztematikus összehasonlítása révén a célul kitűzött fejlesztési munka eredményeire vonatkozó következtetések levonása. 


\section{A mérőrendszer zajforrásainak elemzése, kiküszöbölése}

\subsection{Fotoakusztikus kamra}

A mérőrendszer zajforrásainak elemzése során első lépésben a CARIBIC2 és az SZTE1 rendszer PA kamráit hasonlítottam össze a CARIBIC1 kamráival. Már a szemrevételezés során kiderült a legföbb különbség: A CARIBIC1 rendszer differenciális, míg a CARIBIC2 és az SZTE1 rendszerek egyrezonátoros PA kamrákat tartalmaztak. A differenciális kamrákban a mikrofonok eredő sajátzaja V2-szerese az egyrezonátoros kamráénak, valamint a jelkeltésre használt rezonátorból némi akusztikus energia átszivárog a referenciarezonátorba. Ezek következtében a differenciális kamráknak némileg kisebb az érzékenysége, ezért kis koncentrációk mérésére némileg alkalmasabbak az egy rezonátort tartalmazóak. Laboratóriumi körülmények között még jelentős külső zajok esetében (pl. a kamra közelében elhelyezett nagyteljesítményű vákuumpumpa) sem mutatkozott meg a differenciális detektálás zajcsökkentő hatásának a hiánya. A repülőgépes mérések során - a szerzett tapasztalatok alapján - viszont alkalmazása elengedhetetlen. A CARIBIC2 rendszerben használt PA kamrák lecserélése után a rendszer elkezdett hasznos adatokat szolgáltatni.

\subsection{Mérőelektronika}

A CARIBIC2 rendszer a PA kamrák lecserélése óta időnként zajjal terhelt, de még tudományos célokra alkalmas adatokat szolgáltatott. Ezen időszakos zajosodások felderítésére a CARIBIC2ben alkalmazott vezérlőelektronikával megegyező felépítésű rendszer egyes elemeit kezdtem el tesztelni saját zaj, pontosság, valamint esetleges javíthatóság céljából. Ezen munka során szisztematikusan helyettesítettem minden fontosabb részegységet külső egységekkel.

\subsubsection{Mikrofon tápellátásának a zaja.}

A mikrofon tápellátásának a zaja kimondottan fontos kérdés, hiszen ennek a zaja egy tulajdonképpeni feszültségosztás után direktben jelenik meg a mikrofonerősítőben. A mérések elvégzése során a mikrofonokat egy-egy 2000 Ohmos ellenállással helyettesítettem.Ez az érték nagyjából megegyezik mikrofonok DC ellenállásával. A VT elektronika mikrofonerősítő nyákján a mikrofon tápegységének a zaját mértem meg digitális lock-in erősítő (SR830) segítségével 500, 1000, 2000, 3000, 4000, 5000, 6000, 7000, 8000, 9000 és $10000 \mathrm{~Hz}$ frekvenciákon. Ugyanezen frekvenciákon egy saját készítésű tápegység (LM7805-ös feszültségstabilizátor IC pufferkondenzátorral kiegészítve) IC zaját is lemértem. A különbség 
megdöbbentően nagy, több, mint két nagyságrendnyi volt a saját készítésű tápegység javára. Ezen jelentős zaj potenciális forrását keresve azt találtam, hogy a VT elektronikában a mikrofon tápfeszültségét más elemek is használják.

\subsubsection{Mikrofonerősítő saját zajának tesztelése és összehasonlítása.}

A mikrofon tápellátásának jelentős zaja felvetette a lehetőségét annak, hogy egy másik mikrofonerősítő és egy külön stabilizált mikrofon tápellátás mellett csökkenthető lenne a mérés zaja, ezáltal javítva a legkisebb kimutatható koncentráció értékét. A tesztelésekhez egy INA128-as instrumentális erősítőre alapozva, az adatlapjában található javasolt kapcsolási rajz kismértékű átalakításával készítettem egy 600-szoros erősítésű differenciális mikrofonerősítőt, és a korábban használt stabilizált tápegység IC-vel szolgáltattam a feszültségforrást a mikrofonoknak. Az erősítő meghajtásához egy transzformátoros földfüggetlen tápegységet használtam, mely 0 és \pm 12 V-os ágakkal rendelkezett.

A VT elektronika mikrofonerősítője hasonló felépítésű, az egy INA169-es instrumentális erősítőn alapul és szintén 600-szoros erősítésű.

Az erősítők összehasonlítására két tesztet végeztem el. Az egyikben a mikrofonokat ismételten ellenállásokkal helyettesítve, a másodikban pedig két, PA kamrába beépített mikrofon differenciális zaját mértem a fenti frekvenciákon.

Az egyes teszteknél a két erősítővel nagyon hasonló értékeket kaptam, nem igazán lehet közöttük különbséget tenni. Érdekes tényként figyeltem meg, hogy amennyiben a mikrofonokat kötöttem be az ellenállások helyett, úgy a zaj frekvenciától függetlenül - a mikrofonok saját zajának köszönhetően - mintegy másfél nagyságrendnyit emelkedett.

A tény, hogy nem találtam érdemi különbséget a két erősítő között az igen különböző zajú mikrofon tápfeszültségek ellenére sem azzal magyarázható, hogy a differenciális erősítés igen hatékonyan küszöböli ki a két bemenetre azonos fázisban érkező zajokat. Ez a teszt is alátámasztja a differenciális PA kamra használatának szükségességét zajos környezetekben.

Az erősítőket PA jel detektálása során is összehasonlítottam azonos integrálási idő mellett. Ekkor a lézer (NLK1U5FAAA 1651nm) meghajtását egy analóg feszöltséggel vezérelhető lézermeghajtóval (Thorlabs LDC500) végeztem el. Az összehasonlító mérések során egy 1\%-os koncentrációjú szintetikus levegőben kevert metánpalackból származó gázt kevertem 
szintetikus levegővel, tömegáramlás-szabályozók segítségével. A metánkoncentrációt lépcsőzetesen csökkentve mértem jel/zaj arányokat. Az erősítők között ekkor sem észleltem érdemi különbséget.

Ugyan mind az általam készített erősítő, mind pedig a VT elektronika erősítő moduljának a minősége messze elmarad az audiotechnikában elérhető csúcstechnológiától [107], de ez a tapasztalatok szerint a mikrofonok saját zaja következtében nem jelent hátrányt a PA spektroszkópiában való alkalmazhatóságukban.

\subsubsection{A CARIBIC2 rendszer időnkénti zajosodásának vizsgálata}

Sem az általam végzett laboratóriumi vagy repülőgépes mérések során, sem pedig Dr. Zahn laboratóriumi mérései során nem fordult elő egyszer sem a CARIBIC2 rendszerrel tapasztalt repülés közbeni időnkénti zajosodás. Ezek alapján a zajosodás kiküszöbölésére a megoldást a CARIBIC konténerben kellett keresni. Javaslatomra Dr. Zahn további akusztikus szúrőket, puffer-tartályokat helyezett el, valamint próbálta a mintavevő cső átmérőjének csökkentésével minimalizálni a csövön keresztül bejutó akusztikus zajok mértékét. Ezek összességében valamelyest csökkentették a zajokat, de megszüntetni nem tudták.

A megoldásra Dr. Zahn jött rá, mikor tüzetesen átnézte a CARIBIC konténerben lévő műszerek adatait. Észrevette, hogy az egyik múszer múködésének periodicitása és a zajosodás között egyértelmű kapcsolat van. A másik műszer nem minden repülésen van bekapcsolva és ekkor is csak hosszabb megszakításokkal üzemel és ezen műszer mintavevési periódusai alatt nőtt meg a CARIBIC2 rendszer mérésének a zaja. A másik rendszer üzemeltetőjével való ellenőrzés során észrevették, hogy a mintavételezés alatt az a műszer erősen rázza a mintavevő csövet és ez okozza a CARIBIC2 rendszer zajosodását. Ezt megszűntetve sikerült kiküszöbölni az időnkénti zajosodást is.

\section{3 Összegzés}

Megállapítottam, hogy a CARIBIC2 és az SZTE1 rendszerek repülőgépen való alkalmazhatóságát a bennük elhelyezett PA kamra kialakítása korlátozta. A kamrák differenciálisra való lecserélése után a CARIBIC2 rendszer repülés közben is alkalmassá vált mérések elvégzésére. A kamrákat természetesen az SZTE1 rendszerben is kicseréltem. 
A mérőrendszer saját zajának elemzése során arra a következtetésre jutottam, hogy az alkalmazott mikrofonok saját zaja limitálja a rendszer érzékenységét. A mostaninál kisebb zajú mikrofonok alkalmazása esetén a zajszint a VT elektronika detektálási küszöbe alá menne, amit az erősítés mértékének növelésével - a dinamikus tartomány rovására - lehetne kompenzálni.

A CARIBIC2 rendszer időnkénti zajosodásának a forrását a rendszer üzemeltetőjének, Dr. Zahnnak a segítségével sikerült meghatározni és kiküszöbölni. 


\section{A hullámhossz beállító algoritmus pontosságának javítása}

\subsection{Korábban kifejlesztett eljárás}

A kutatócsoportban korábban kifejlesztésre került egy eljárás [105], amely segítségével hangolható diódalézerek hullámhosszát gyorsan lehet beállítani a munkapontra. Az eljárás fejlesztésekor a pontosság mellett fontos szempont volt, hogy az alkalmazásához szükséges mérési idő rövid legyen. Egy ilyen eljárás alkalmazására három ok miatt van szükség:

- a DFB diódalézerek hullámhossza hőmérséklet kis mértékű megváltozása esetén is jelentősen, a mérés pontosságát befolyásoló mértékben megváltozik,

- a DFB diódalézerek hullámhossza különböző öregedési effektusok következtében folytonosan változik [108-112],

- a lézervezérlő áramkörben lévő alkatrészek öregednek, amit virtuális lézerhullámhossz- változásként lehet észrevenni.

Hasonló célú eljárások során a lézer hullámhosszát egy etalonhoz kell hasonlítani. A lézer hullámhosszát át kell hangolni az etalonon, a válaszjelben pedig egy karakterisztikus referenciapontot kell definiálni, a hozzá tartozó lézer-hangolási paramétereket pedig meghatározni. Ezután ha a meghatározott paraméterekkel üzemeltetjük a lézert, akkor a definiált karakterisztikus ponthoz tartozó hullámhosszon fog üzemelni. Sokszor előfordul, hogy a referencia-hullámhossz nem egyezik meg a beállítandó hullámhosszal, ekkor meg kell határozni a kettő különbségéhez tartozó hangolási-paraméter különbséget is, melyet alkalmazva már nagy pontossággal beállítható lesz a munkapont is.

Hullámhossz etalonként Fabry-Perot interferométert, illetve elnyelési vonalakat (pl.: Lamb dipólus) szokás alkalmazni. Az előbbi hátránya, hogy mesterséges etalonok, így elhangolódhatnak. Az elnyelési vonalak esetében is fennáll ennek a lehetősége a hőmérséklet és nyomásfüggő vonalalak és központi hullámhossz miatt. Abszolút pontosságot csak frekvencia-fésű [113] alkalmazásával lehet elérni, azonban ezek használata hordozható spektroszkópiai rendszerekben nem kivitelezhető, valamint gázdetektálási célra fejlesztett mérőrendszerek esetén nem is szükséges az általuk biztosított pontosság.

Diódalézerek esetén a hullámhossz-stabilizálást a hőmérséklet nagypontosságú stabilizálásával, a munkapontra való beállítást a megfelelő hőmérséklet kiválasztásával, 
valamint az áramerősség finomhangolásával szokás megtenni. A Kutatócsoport által korábban kifejlesztett eljárás ezen utóbbi feladat megoldására szolgál:

Az eljárás során a lézerre adott áramerősség-hullámformát egy szinuszos moduláció és egy hozzá képest kis frekvenciájú háromszögjel összegeként állítjuk elő. A szinuszos moduláció a PA jelkeltéshez, míg a háromszögjel a lézer központi hullámhosszának hangolásához szükséges. A lézervezérlés paramétereit úgy kell beállítani, hogy a háromszögjel segítségével áthangoljuk a lézert a vízgőz (vagy egyéb, keskeny elnyelési vonallal rendelkező komponens) egy elnyelési vonalán. A mérés során a mikrofonnal mért jelet digitalizáljuk. A kapott PA időjelnek vesszük a háromszögjel felfutásához tartozó részét és referenciapont meghatározáshoz eltároljuk. Az így kapott PA időjel első ránézésre egy szinuszos hullámforma, amelynek a burkolóját egy hullámhossz-modulált spektrum adja. Ebben a hullámformában definiálunk, illetve keresünk referenciapontot.

A korábbi eljárás során az időjelben maghatároztuk a modulációs periódusonkénti lokális maximumhelyeket, valamint az abszolút maximumértéket. A meghatározott lokális maximumhelyek közül meghatároztuk az abszolút maximum/2 értékhez legközelebb eső lokális maximum helyét: az ahhoz az időponthoz tartozó fürészfogjel-áramerősségként definiálva a referenciaponthoz tartozó lézer-áramerősséget. Az eljárás alkalmazása során - a mérés zaja miatt - előfordulhat, hogy $\pm 1-3$ lokális maximumhelynél találjuk meg a referenciapontot, ráadásul a mérés hullámhossz-béli kvantumnagysága $155 \mathrm{fm}$. Ez a hullámhossz-bizonytalanság érezhetően befolyásolta a PA mérések érzékenységét különösen alacsony nyomásokon. Következésképpen szükségessé vált az eljárás pontosságának, precizitásának javítása.

\section{2 Új referenciapont}

A fent bemutatott mérés sok szempontból hasonlít a hullámhossz-modulált spektrum felvételéhez, lényegi különbség csak a lézer központi hullámhosszának hangolási sebességében van. Hullámhossz-moduláció mellett felvett PA spektrum alakja kis modulációs mélység esetén az elnyelési vonal deriváltjával lesz arányos. Az elnyelési vonal két oldalán a deriváltak előjele ellentétes, ami $180^{\circ}$-os fázisváltozásként jelenik meg lock-in technikát használva. A fázistoláshoz tartozó hullámhossz megegyezik az elnyelési vonal maximumhelyével. Ennek a fázistolásnak a gyors áthangolás esetén is meg kell jelennie a 
mérhető jelben. Ezt a megjelenést numerikus szimulációkkal igazoltam, majd pedig kísérleteken keresztül megvizsgáltam a referenciapontként való alkalmazhatóságát.

\subsection{A jelkeltés modellezése}

A szimultán hangolás és modulálás során keltett PA időjel időbeli alakjának leírásához a fotoakusztika Rosencwaig-féle tárgyalásmódjából $[93,94]$ indultam ki, mely szerint a PA időjel arányos az elnyelt fényteljesítmény idő szerinti deriváltjával.

Legyen az elnyelési vonal nyomáskiszélesedett, azaz Lorentz profillal jellemezhető:

$$
\alpha(\lambda)=\frac{\alpha_{\max }}{1+\left(\frac{\lambda-\lambda_{\text {vonal }}}{F W H M}\right)^{2}}
$$

ahol $\alpha_{\max }$ az elnyelési vonal maximumértéke $\left(\mathrm{ppm}^{-1} \times \mathrm{m}^{-1}\right), \lambda$ a hullámhossz $(\mathrm{m}), \lambda_{\text {vonal }}$ a vonal maximumhelye $(\mathrm{m}), \boldsymbol{F W H M}$ a vonal félértékszélessége $(\mathrm{m})$. A lézerre adott áramerősség hullámforma a fürészfogjel felfutó éle alatt:

$$
I(t)=I_{0}+g \cdot t+h \cdot \sin (\omega \cdot t)
$$

ahol Io egy DC offszet $(\mathrm{mA}), \boldsymbol{g}$ a lézerre jellemző áramerősség hangolási együttható $(\mathrm{m} / \mathrm{mA}), \boldsymbol{h}$ az alkalmazott moduláció amplitúdója (mA), $\omega$ a moduláció körfrekvenciája ( $\mathrm{rad} / \mathrm{s})$, valamint $\boldsymbol{t}$ az idő (s). Felhasználva az 2-3. és 8. egyenleteket megkapjuk a lézer hullámhosszát és teljesítményét az idő függvényében:

$$
\begin{aligned}
& \lambda(t)=\lambda_{0}^{\prime}+a \cdot g \cdot t+j \cdot h \cdot \sin (\omega \cdot t), \\
& P(t)=P_{0}^{\prime}+j \cdot g \cdot t+j \cdot h \cdot \sin (\omega \cdot t),
\end{aligned}
$$

Ahol $\lambda_{0}{ }^{\prime}$ és $\boldsymbol{P}_{0}{ }^{\prime}$ a hullámhossznak és a teljesítménynek a $\mathrm{t}=0 \mathrm{~s}$ időpontban felvett értékei. A 9. egyenletet behelyettesítve a 7.-be megkapjuk az abszorpciós együttható időbeli változását:

$$
\alpha(t)=\frac{\alpha_{\max }}{1+\left(\frac{\lambda_{0}^{\prime}+a \cdot g \cdot t+j \cdot h \cdot \sin (\omega \cdot t)-\lambda_{\text {vonal }}}{F W H M}\right)^{2}}
$$

Gyenge abszorpciót feltételezve a Lambert-Beer törvényt Taylor sorfejtésének lineáris tagjával közelítve az elnyelt fényteljesítményre kapjuk: 


$$
P_{a b s}=P_{b e} \cdot \alpha \cdot L \cdot c
$$

Behelyettesítve a 10. és 11. egyenleteket:

$$
P_{a b s}(t)=\frac{\alpha_{\max } \cdot\left(P_{0}^{\prime}+j \cdot g \cdot t+j \cdot h \cdot \sin (\omega \cdot t)\right)}{1+\left(\frac{\lambda_{0}^{\prime}+a \cdot g \cdot t+j \cdot h \cdot \sin (\omega \cdot t)-\lambda_{\text {vonal }}}{F W H M}\right)^{2}} \cdot L \cdot c .
$$

Az 6. egyenletnek megfelelően a PA jel konstans szorzó erejéig való meghatározásához a fenti egyenletet kell deriválni, majd pedig a PA kamra rezonanciagörbéjével, mint akusztikus átviteli függvénnyel korrigálni kell:

$$
P A(t)=\text { Konst } \cdot \mathbb{F}^{-1}\left[H_{\text {kamra }}(\omega) \cdot \mathbb{F}\left(\frac{d P_{a b s}(t)}{d t}\right)\right]
$$

Ahol $F$ és $\mathrm{F}^{-1}$ a Fourier transzformáció és inverze, $\boldsymbol{H}_{\text {kamra }}(\omega)$ pedig a PA kamra akusztikus átviteli függvénye, melynek mind valós, mind képzetes részét a kamra rezonancia-görbéjének méréséből illesztéssel (Ábra 12, Táblázat 1) határoztam meg:

$$
H(\omega)=\frac{F}{\sqrt{k-m \cdot \omega^{2}+l \cdot \omega^{2}} \cdot e^{\text {i.arctan } \frac{l \cdot \omega}{k-m \cdot \omega^{2}}}} .
$$

\begin{tabular}{ccccc}
\hline \hline paraméter & $\mathrm{F}$ & $\mathrm{k}$ & $\mathrm{m}$ & $\mathrm{l}$ \\
\hline illesztett számérték & $3,816^{*} 10^{14}$ & $4,078^{*} 10^{15}$ & $4,652 * 10^{6}$ & $1,251^{*} 10^{10}$
\end{tabular}

Tá $\overline{\overline{b l a ́ z a t ~ 1: ~ A z ~ a l k a l m a z o t t ~ P A ~ k a m r a ~ a ́ t v i t e l i ~ f u ̈ g g v e ́ n y e ́ n e k ~ i l l e s z t e t t ~ d i m e n z i o ́-m e n t e s ~}}$ paraméterei. 


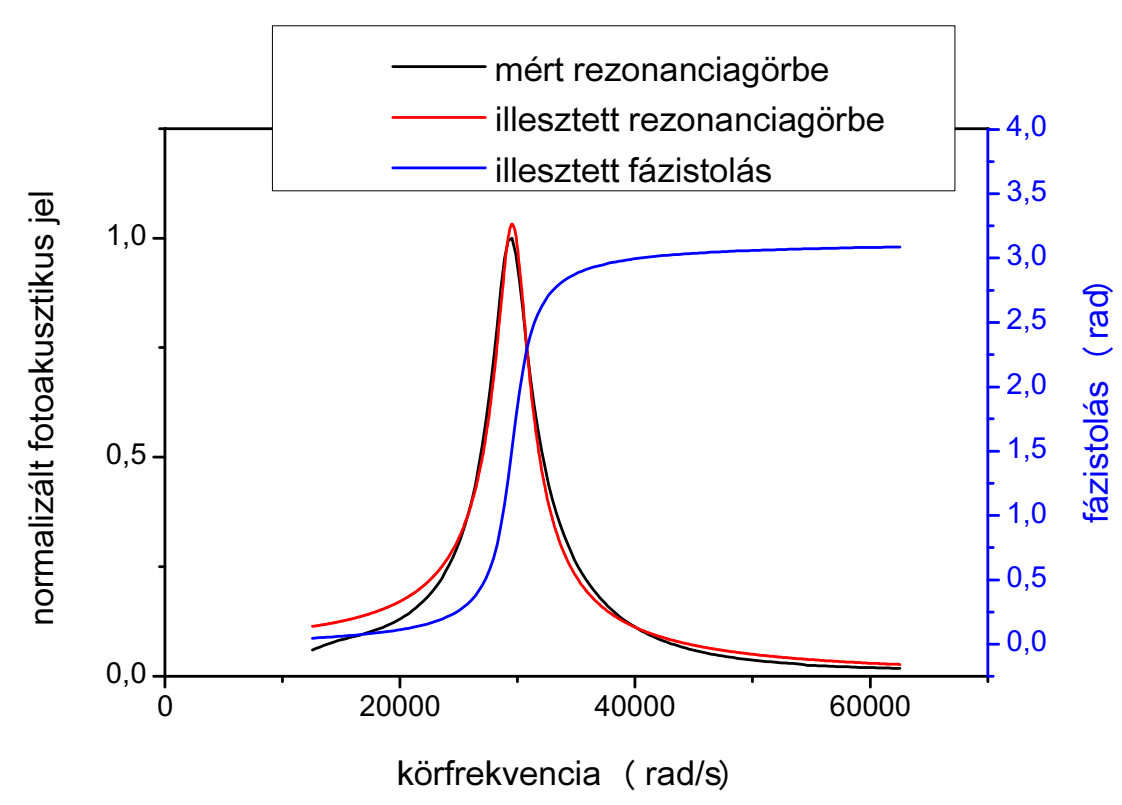

Ábra 12: Az alkalmazott PA kamra normált átviteli függvénye. Az illesztés pontossága nem ideális, ezt a mikrofon érzékenységének a frekvencia-függése okozza.

A szimuláció során olyan paramétereket használtam (Táblázat 2), amelyek nagyságrendileg megegyeznek a mérések során alkalmazottakkal.

\begin{tabular}{cccc}
\hline paraméter & felhasznált érték & paraméter & felhasznált érték \\
\hline $\mathrm{a}$ & $5 \mathrm{pm} / \mathrm{mA}$ & $\alpha_{\max }$ & $4^{*} 10^{-5} \mathrm{ppm}^{-1 * \mathrm{~m}^{-1}}$ \\
$\mathrm{j}$ & $0,16 \mathrm{~W}^{*} \mathrm{~A}^{-1}$ & $\omega$ & $2 \pi^{*} 5000 \mathrm{~Hz}$ \\
$\mathrm{P}^{\prime}{ }^{\prime}$ & $15 \mathrm{~mW}$ & $\lambda_{0^{\prime}}$ & $1390 \mathrm{~nm}$ \\
$\mathrm{~g}$ & $200 \mathrm{~mA}^{*} \mathrm{~s}^{-1}$ & $\lambda_{\text {vonal }}$ & $1390,5 \mathrm{~nm}$ \\
$\mathrm{~h}$ & $8 \mathrm{~mA}$ & FWHM & $0,05 \mathrm{~nm}$ \\
\hline \hline
\end{tabular}

Táblázat 2: A numerikus szimuláció során alkalmazott paraméterek.

A szimuláció eredményéül kapott időjel (Ábra 13) jellegre megegyezik azzal, amit a mérések során kaphatunk, ami a modell helyességét igazolja. A kapott időjelből a későbbiekben részletezett módon, Gábor transzformációval meghatároztam a jel 1 komponenséhez tartozó fázist. A fázisban megjelent a várt $180^{\circ}$-os változás. 


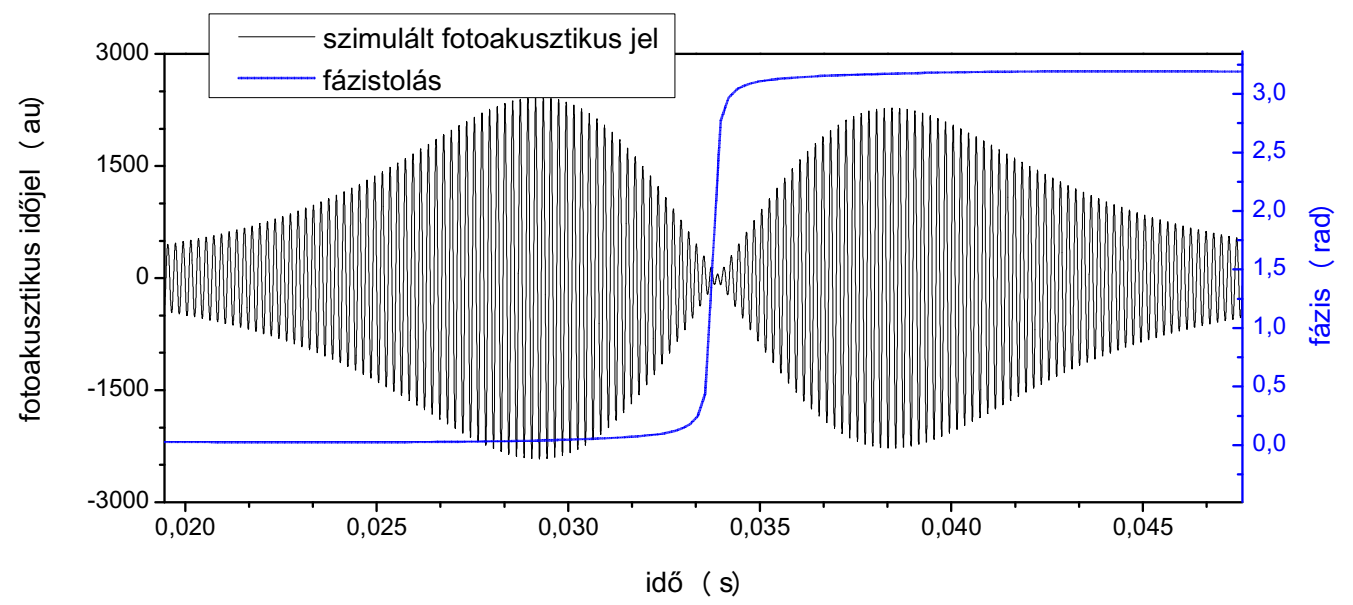

Ábra 13: A numerikus szimulációval meghatározott PA időjel és fázisa.

\subsection{Referenciapont meghatározása}

A $180^{\circ}$-os fázistolás megjelenését és referenciapontként való felhasználhatóságát mérések során is megvizsgáltam. A jelkiértékelési eljárás megértéséhez szükséges a VT elektronika - kapcsolódó mérésekhez tartozó - múködésének a bemutatása is. Az elektronika egy 16 bites $D A C^{26}$-cal vezérelt áramgenerátorral hajtja meg a rá kapcsolt lézert $\left(2^{16}\right.$ bináris érték= $250 \mathrm{~mA}$ ). A jelkeltés és a mintavételezés frekvenciáját minden esetben a moduláció frekvenciájának nyolcszorosa. (Opcionálisan 64/32/16-szoros értéknek is állítható.) A 8. egyenletben definiált hullámformát 4096 pontból állítja elő úgy, hogy a konstans lo értékhez tartozó bináris értékhez minden egyes jelkeltéshez tartozó időpontban hozzáad 1-et, valamint a megfelelő szinuszos tagot. Így a hangolás sebessége $\mathrm{mA} / \mathrm{s}$-ban mérve függ a modulációs frekvenciától. A vezérlőjel előállításának és a mikrofonjel digitalizálásának ez a módja jelentős mértékben leegyszerűsíti a jel kiértékelését. Ezen felül a mérés zajának csökkentése érdekében lehetőség van egymást követően felvett PA időjelek átlagolására is.

A mért jel kiértékelését időbontott spektrális analízissel, négyszögablakos Gábor transzformációt használva a lézer modulációs frekvenciáján végzem el:

\footnotetext{
${ }^{26}$ Digital-Analog Converter
} 


$$
G\{P A(t)\}=\frac{1}{\sqrt{2 \pi}} \int_{t-\frac{T}{2}}^{t+\frac{T}{2}} P A\left(\mathrm{t}^{\prime}\right) \cdot \mathrm{e}^{i \cdot \omega \cdot t^{\prime}} d t^{\prime}
$$

ahol T a moduláció periódusideje $(\mathrm{s})(\mathrm{T}=2 \pi / \omega)$. A fázistolási görbét az alábbi módon kapjuk:

$$
\varphi(t)=\arctan \frac{\operatorname{Im}[G\{P A(t)\}]}{\operatorname{Re}[G\{P A(t)\}]}-\frac{2 \pi t}{T} \bmod 2 \pi,
$$

ahol Im és Re a képzetes és valós részeket jelölik, a különbség második tagja pedig a lézer modulációjának a t időpontbeli fázisát adja. Úgy találtam, hogy a fázistolási görbének az inflexiós pontja kellő pontossággal meghatározható és referenciapontként alkalmazható, annak a meghatározásához a fázistolási görbét deriválni kell, majd pedig a maximumértéket meg kell keresni.

A fent bemutatott jelkiértékelés eljárást az alábbi módon valósítottam meg:

1. A mért 4096 elemú tömböt 8 elemnyi résztömbökre bontottam el úgy, hogy az résztömbök kiválasztáshoz tartozó kezdő indexeket egyesével növeltem. Ennek eredményeként 4089 tömböt kaptam.

2. Az egyes tömböket 8 elemmel mintavételezett periódusnyi szinusz és koszinusz függvénnyel megszoroztam, az egyes szorzatokat szummáztam. Konstans szorzótól eltekintve eredményül kaptam a Fourier transzformált képzetes és valós részét.

3. A 17. egyenletnek megfelelően meghatároztam a fázistolási görbét.

4. A fázistolási görbét a deriválás előtt 8 elemú futóátlaggal simítottam, hogy elkerüljem a zaj deriválását.

5. A simított görbét deriváltam: a tömböt egy elemmel elcsúsztatva kivontam önmagából.

6. Meghatároztam a maximumhelyet.

A fenti lépések számos esetben konstans szorzók elhagyását jelentik, azonban azok alkalmazása a jelalakra nem, csak a jelnagyságra lennének hatással, így a maximumhely meghatározása során csak a számítási igényt növelték volna. A fenti lépésekből álló eljárást egyszerűsége révén a VT elektronika DSP-jében is lehetett implementálni, amit a Videoton Zrt. Fejlesztési Osztályának munkatársai meg is tettek. 


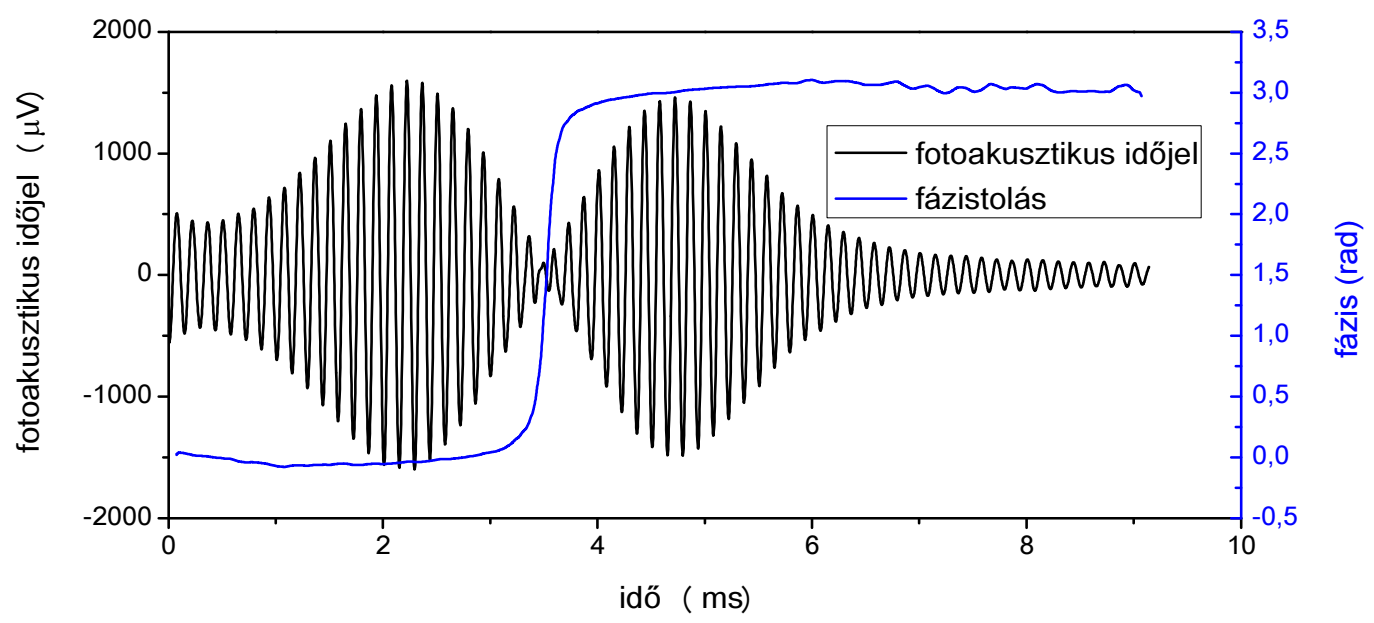

Ábra 14: példa a mért PA időjelre és a belőle meghatározott fázistolási görbére. A mérés modulációs periódusonként 64 mintavételezéssel történt, a jel alakjának jobb láthatóságáért.

\subsection{Az elvégzett tesztek}

A fenti eljárás referenciapont-meghatározási eljárásként való alkalmazásához számos tesztet végeztem el, hogy meghatározzam a referenciapont-meghatározás precizitását, hosszú távú stabilitását, nyomástól és abszorpciós együtthatótól való függését.

A mérések automatizált elvégzésére a VT elektronikához készített vezérlő szoftver (PAMS) segítségével nem volt mód, ezért LabVIEW fejlesztői környezetben elkészítettem egy programot, ami megfelelő soros-porti kommunikációval emulálta a PAMS program vonatkozó részét. $A z$ új program segítségével a PAMS-ban beállított mérési paraméterekkel automatizáltan tudtam végezni a méréseket, ami alapvető fontosságú volt a hosszú távú stabilitás meghatározásához.

A kísérleti elrendezésben az alap PA rendszert, - mely egy VT elektronikából, egy DFB diódalézerből (NEL NLK1E5E1AA, 1392 $\pm 1,5 \mathrm{~nm}$ ) és egy 40 $\pm 0,1^{\circ} \mathrm{C}$ hőmérsékleten stabilizált PA kamrából állt - kiegészítettem egy nyomásstabilizáló rendszerrel, valamint egy nedvességgenerátorral is (Ábra 15).

A lézer hangolási tartományába eső vonalak közül egy gyengébbet (1391,66 nm, $3 \times 10^{-6} \mathrm{ppm}^{-1} \times \mathrm{m}^{-1}[100]$ (Ábra 24)) használtam. A mérések során mind a lézer, mind a lézer- 
tokozásának a hőmérsékletét stabilizáltam. A vezérlőelektronika által szolgáltatott lézer NTC ellenállás adatokból csak becsülni lehet a hőmérséklet stabilitását: $1 \mathrm{~m}^{\circ} \mathrm{C}$-nál nem volt bizonytalanabb, ami 100 fm-nél nem nagyobb hullámhossz-bizonytalanságot jelent.

A nyomásstabilizáló egy léptetőmotorral vezérelt tűszelepből, egy nyomásmérőből, egy áramlásszabályzóból és egy vákuumpumpából állt. Ezzel a rendszerrel az áramlási sebességet 0,2-2 slpm közötti értékre beállítva 50 és 950 mbar között tetszőleges nyomást \pm 1 mbar precizitással be tudtam állítani. A léptetőmotor meghajtót egy NI 6008-as multifunkciós DAQ eszköz és teljesítmény meghajtó segítségével készítettem el, a vezérlését LabVIEW környezetben valósítottam meg.

Nedvességgenerátorként részben a bevezetésben bemutatott SZTE nedvességgenerátort, részben pedig kriosztáttal $10^{\circ} \mathrm{C}$ hőmérsékleten stabilizált vízen buborékoltattam át szintetikus levegőt.

A mérések során az alábbi paramétereket alkalmaztam:

\begin{tabular}{cc}
\hline \hline paraméter & érték \\
\hline $\mathrm{h}$ & $6 \mathrm{~mA}$ \\
$\mathrm{~g}$ & $215 \mathrm{mAs}^{-1}$ \\
$\omega$ & $2 \pi^{*} 7000 \mathrm{~Hz}$
\end{tabular}

Táblázat 3: A mérések során a lézerre kapcsolt áramerősség hullámforma előállításához használt paraméterek. 


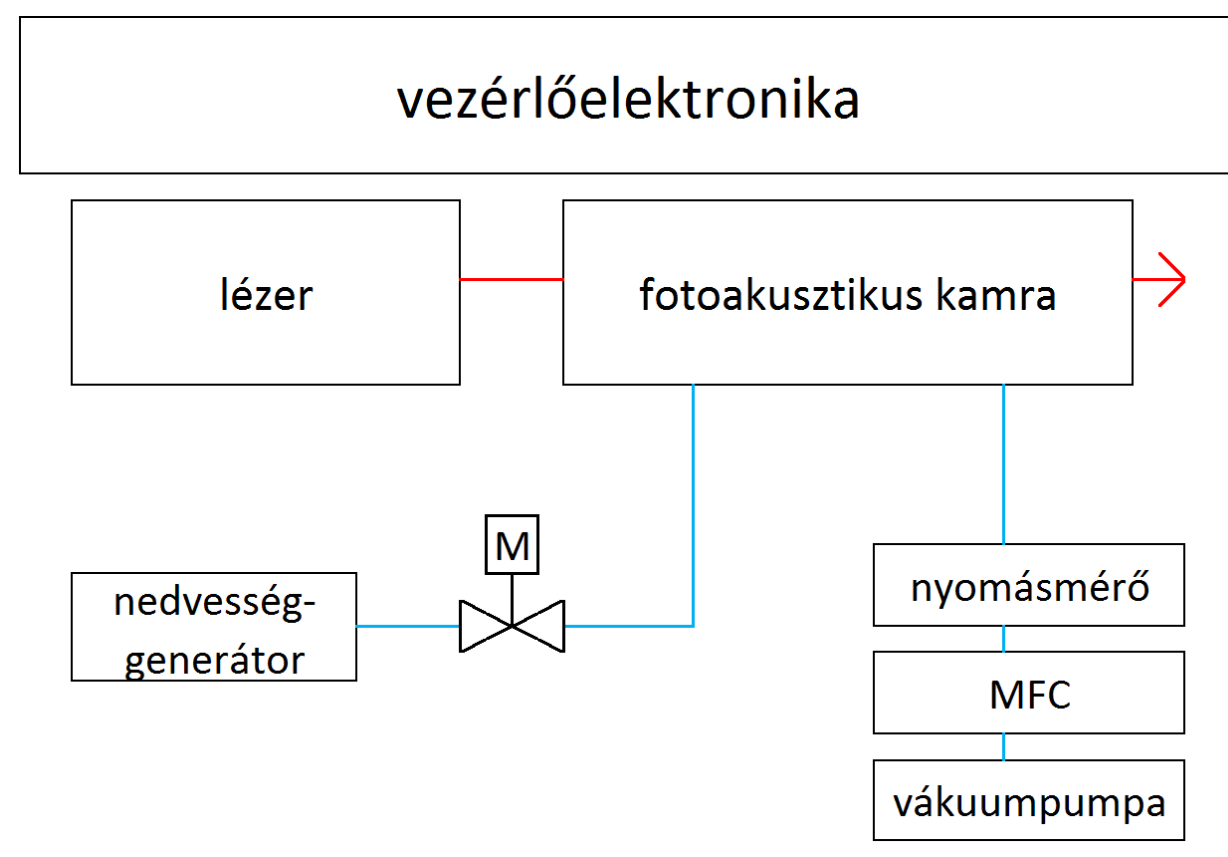

Ábra 15: A hullámhossz-referenciapont- meghatározási eljárás tesztelése során alkalmazott kísérleti elrendezés. /M: léptetömotor, MFC (Mass Flow Controller): tömegáramlásszabályozó/

\subsubsection{Az eljárás precizitása}

Az eljárás precizitásának meghatározásához elvégeztem 1000 mérést, rögzítve a VT elektronikába korábban programozott eljárással a referenciapontot, valamint utólagosan feldolgozva az új eljárással meghatározottat. A mérések során a nyomást 950 mbar-on stabilizáltam a koncentrációt 12200 ppmV körüli értéken tartva.

10 mérés átlagolása esetén értem el a legkisebb bizonytalanságot, ekkor a régi eljárással a mérés szórása $94 \mu \mathrm{A}-n e k$, míg az újjal 9,7 $\mu \mathrm{A}-n e k$ adódott. Ez hullámhossz-béli bizonytalanságban $5 \mathrm{pm} / \mathrm{mA}$ hangolhatósággal számolva 470 illetve 48,5 fm-nek felel meg. Azaz az új eljárás alkalmazásával közel egy nagyságrenddel kisebb bizonytalansággal lehet meghatározni a referencia-hullámhosszhoz tartozó áramerősséget ugyanazon mérés esetén. Ugyanakkor a 48,5 fm értéket lehet, hogy a lézer hőmérsékletének zaja limitálja. A bruttó mérési idő ekkor 0,5 s körüli, ami tartalmazza a mérési módok közötti váltást, 10 mérés átlagolását és a jelkiértékelést is. Az elért hullámhossz-beállítási bizonytalanság 180 mbar nyomás esetén $0,1 \%$ körüli bizonytalanságot jelent a PA jelben, azaz kisebb, mint a repülési magasságra jellemző alacsony koncentrációkhoz tartozó relatív zajszint. 


\subsubsection{Az eljárás nyomásfüggése}

A PA kamrában lévő nyomást 50 és 950 mbar között lassan változtatva meghatároztam az eljárás nyomásfüggését (Ábra 16). A teljes tartományon mintegy 3 pm-nyi változást tapasztaltam; a változás egy parabolával közelíthető:

$$
\Delta \lambda=5,405 \frac{\mathrm{fm}}{\mathrm{mbar}} \cdot p-0,00188 \frac{\mathrm{fm}}{\mathrm{mbar}^{2}} \cdot p^{2}
$$

ahol $\boldsymbol{p}$ a nyomás (bar). Ez a nyomásfüggés lényegileg megegyezik a mérés során alkalmazott elnyelési vonalnak a nyomásfüggő vonaleltolódásával [114].

Megállapítható hogy az eljárás eredménye nagy pontossággal követi az elnyelési vonal hullámhosszának a megváltozását. Megfelelő nyomásfüggő kalibráció után a nyomás 1 mbaros hibája esetén mindössze $4 \mathrm{fm}$ a hullámhossz-referencia hibája, ami 1 nagyságrenddel kisebb, mint a mérés zaja.

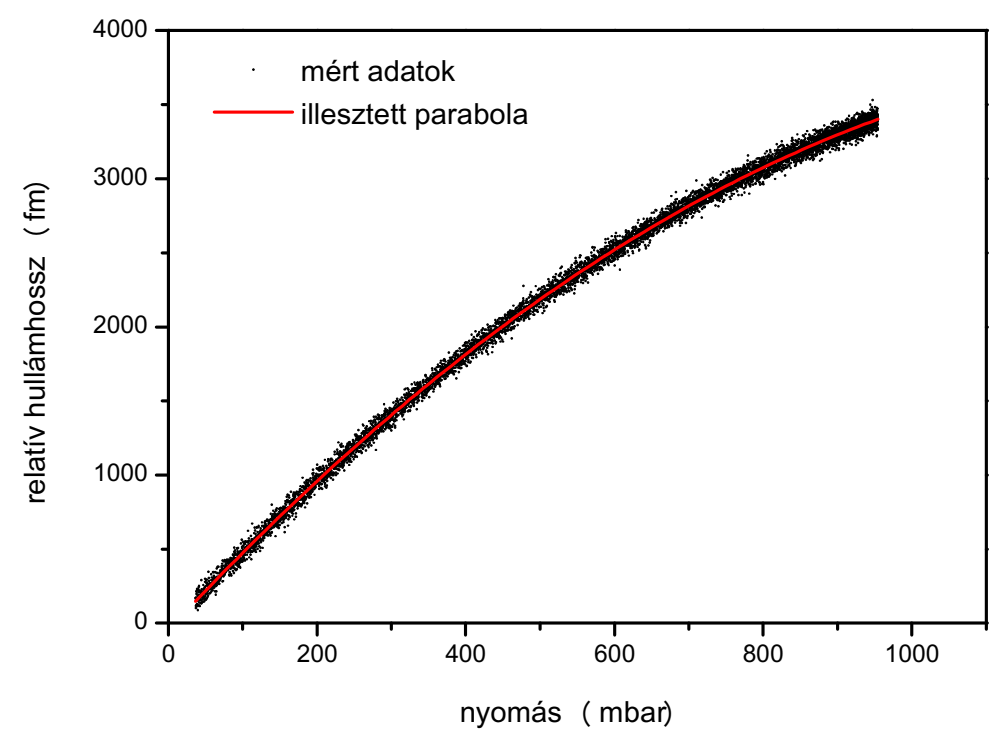

Ábra 16: A referenciapont relatív hullámhosszának nyomásfüggése.

\subsubsection{Az eljárás abszorpciós együtthatótól való függése}

A mérés alatt az SZTE nedvességgenerátoron keresztül vezettem nedvesített szintetikus levegőt a PA kamrába. A nedvességgenerátor felmelegedése során folyamatosan rögzítettem a PA időjelet, valamint a harmatpontot. A harmatpontból meghatároztam a koncentrációt, majd pedig az abszorpciós együtthatót. Az időjelek kiértékelése során azt tapasztaltam, hogy 
a referenciaponthoz tartozó áramerősség-érték független az abszorpciós együttható $\left(\alpha_{\max } \times c\right)$ mértékétől, azonban kis koncentrációk esetén a bizonytalanság jelentősen megnőtt. Az időjelek változó hosszúságú átlagolásából meghatároztam azt a mérési időt, ami az 50 fm

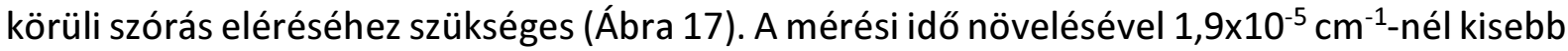
abszorpció esetén az átlagolási idő növelésével sem lehet elérni az 50 fm-es szórást. Ekkor a mikrofonjel jel/zaj aránya 30 körüli.

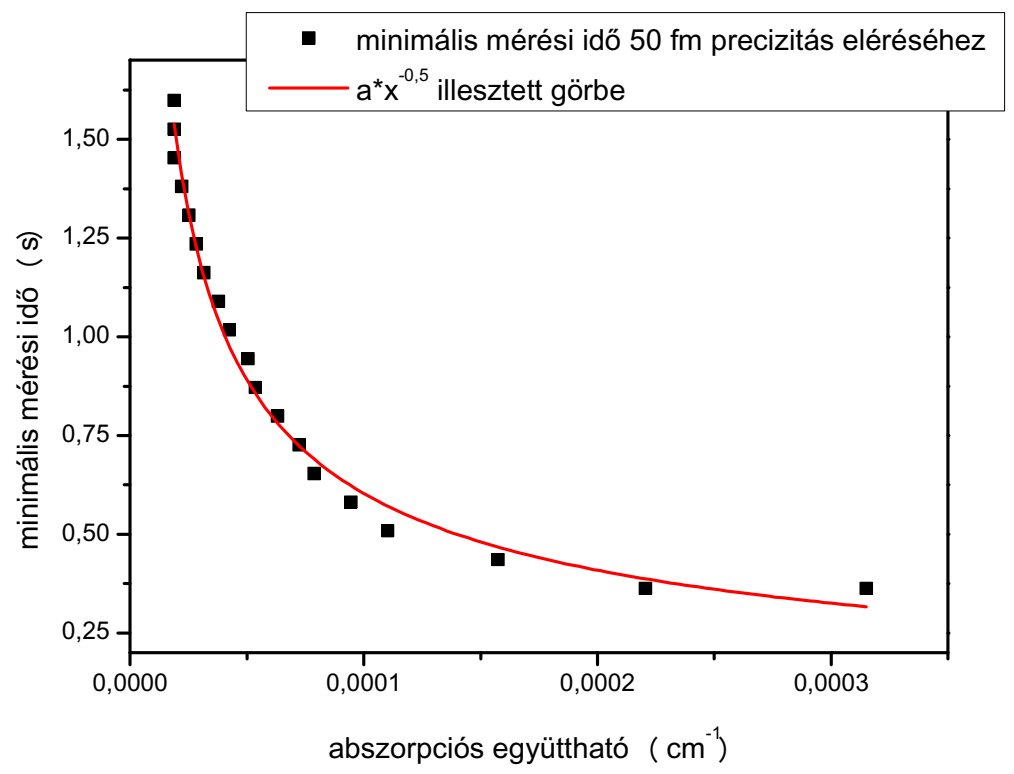

Ábra 17: Az 50 fm körüli precizitáshoz szükséges mérési idő az elnyelési vonal maximumhelyéhez tartozó abszorpciós együttható függvényében.

\subsubsection{Hosszú távú stabilitás}

Az eljárás hosszú távú stabilitásának meghatározásához egy harminc napos tesztet végeztem el, amely során folyamatosan rögzítettem a PA időjeleket, valamint naponta egyszer elvégeztem egy nagyfelbontású, lassú PA spektrum-mérést is. Az utóbbi során mért görbéből Voigt-profil illesztéssel határoztam meg az elnyelési vonal maximumhelyét.

A mérések során a Voigt-profil illesztéssel meghatározott referenciapont zajszinten belül megegyezett az új eljárással meghatározottakkal. Mindkettővel meglepően nagy, 3,36 $\mu \mathrm{A} / \mathrm{nap}$ lézer hullámhossz-változás sebességet észleltem. A mérésekből kivonva a lézer hullámhossz változását a mérés szórása 10,6 $\mu \mathrm{A}$, ami nagyjából 10\%-kal nagyobb, mint a rövidtávú precizitás. 


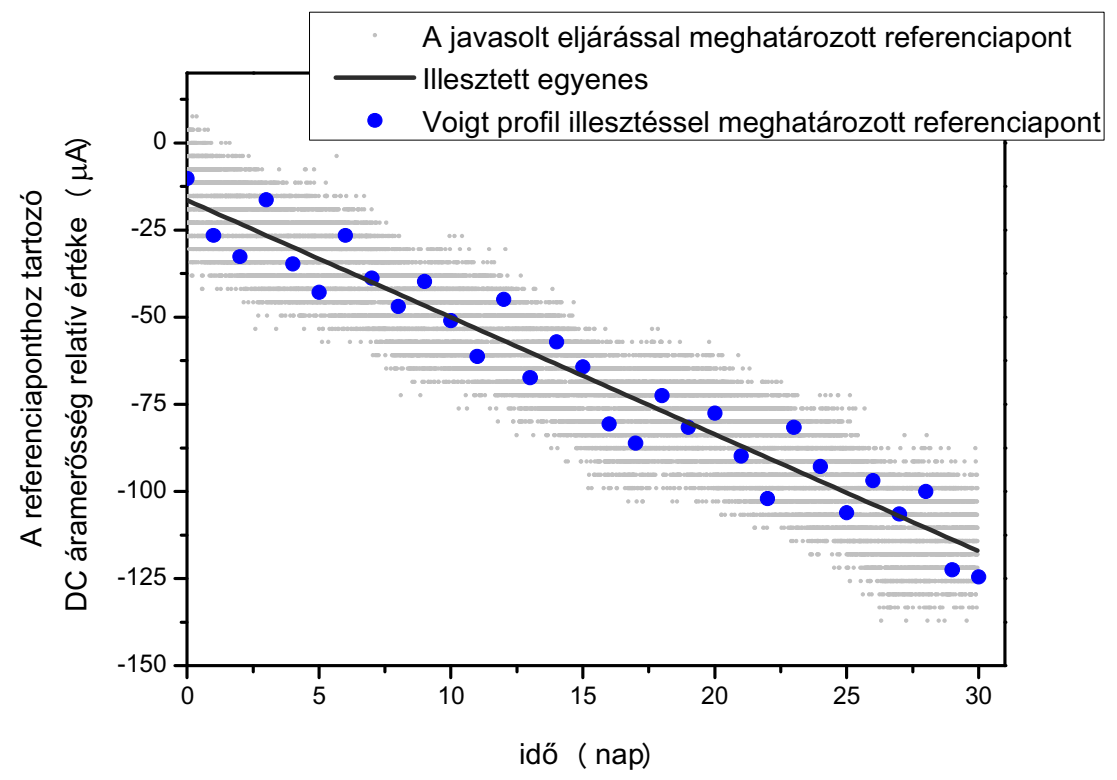

Ábra 18: A lézer referencia-hullámhosszhoz tartozó áramerősségének a változása. Látható, hogy a két módszerrel meghatározott referenciapont ugyanolyan sebességgel változik.

\subsection{Az eljárás alkalmazhatósága egyéb mérési technikáknál}

A Fourier transzformáció deriválási szabálya szerint a transzformált, valamint a derivált transzformáltja mindössze $90^{\circ}$-os konstans fázistolásban különböznek egymástól, tehát az elnyelt fényteljesítmény és a PA jel fázistolási görbéje mindössze konstans $90^{\circ}$-ban különbözik egymástól. Ennek értelmében a kidolgozott eljárásnak alapvető feltétele nem a PA jelkeltés, hanem az elnyelt fényteljesítménnyel arányos jel rögzítése. Ez pedig megvalósítható akár DATDL vagy $2 f$ TDL rendszerekkel is 2 fotodióda különbségi jelét mérve.

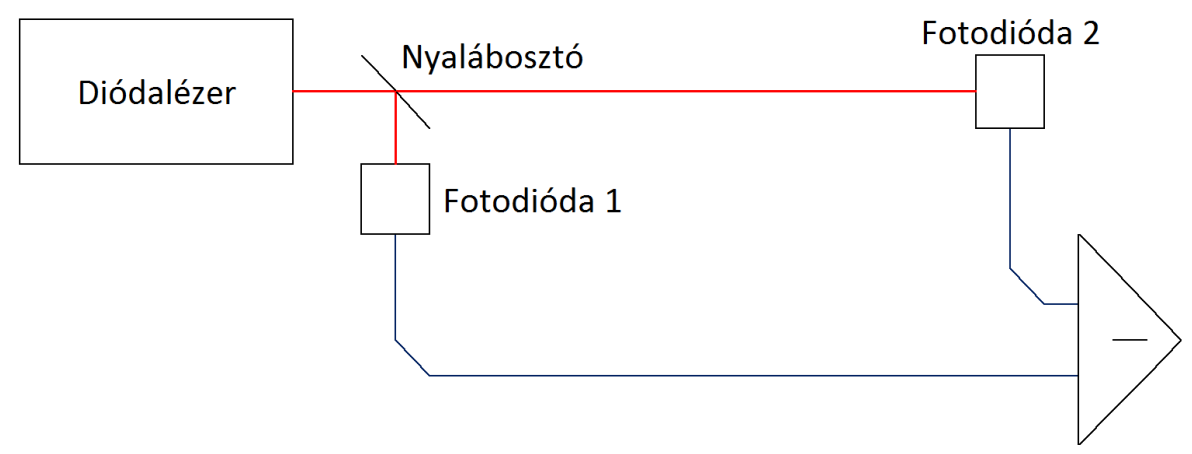

Ábra 19: Elrendezés DA-TDL vagy 2f TDL mérésekhez. 


\section{7 Összegzés}

A kutatócsoport által korábban kidolgozott - elosztott visszacsatolású diódalézerek hullámhosszának beállítására szolgáló - eljárást új, fázistolási görbe inflexiós pontjának meghatározásán alapuló jelkiértékelési algoritmus kifejlesztésével sikerült hozzávetőlegesen egy nagyságrenddel pontosabbá tennem. Kísérletileg igazoltam, hogy az eljárás alkalmazásával a hullámhossz beállítás bizonytalansága $(1 \sigma) 50 \mathrm{fm}$ értékre csökkenthető (ami $4 \times 10^{-8}$ relatív hullámhossz-bizonytalanságnak felel meg). Továbbá módszert dolgoztam ki, amelynek segítségével az eljárás által meghatározott hullámhossz-referencia értékeket megfelelő módon korrigálni lehet, amennyiben a légköri nyomás megváltozik. Megállapítottam, hogy hozzávetőlegesen 10 mbar nyomásváltozás okoz akkora eltérést, amelynél a korrekciós módszert már alkalmazni szükséges. Megjegyzendő, hogy a kidolgozott új eljárás precizitása révén alkalmas az elnyelési vonalak ütközési eltolódásának a vizsgálatára is. $[115,116]$ 


\section{Kalibrációs és jelkiértékelési eljárás fejlesztése}

A rendszer kalibrálása során a legnagyobb kihívást az nyomásfüggő vonalalak, a nyomásfüggő központi hullámhossz, és a mérések során szükséges 5-6 nagyságrendnyi dinamikus tartomány jelenti. A korábban kidolgozott eljárások fő célja az volt, hogy a kalibrációs görbéket be lehessen programozni a VT elektronikába valós idejű jelfeldolgozást megvalósítva. Ez számos egyszerűsítést követelt meg, ami miatt a rendszer pontossága nem volt kielégítő.

Az új kalibrálási és jelfeldolgozási eljárás során a fő célom az volt, hogy a teljes nyomás és koncentrációtartományon a mérőrendszer zajszinten belül felcserélhető legyen a kalibrálás során alkalmazott referenciamúszerrel. A mérések során a korábban bemutatott SZTE nedvességgenerátort alkalmaztam referenciamúszernek. A nedvességgenerátor pontossága 10 ppm koncentráció alatt - az OMH-nál elvégzett kalibráció ellenére - megkérdőjelezhető, de ezen a tartományon 1 ppm-en belül reprodukálhatóan múködik, míg magasabb koncentrációk esetén a kalibrálása során használt referenciaműszerrel zajszinten belül felcserélhető.

A VT elektronikára alapozott mérések során annak korlátozott adattároló kapacitása miatt mindenképpen szükséges egy adatgyưjtő számítógép jelenléte, amelyet az adatrögzítés mellett fel lehet használni az adatok kiértékelésére is, amennyiben az valós időben szükséges. Ehhez egy olyan eljárást kellett kidolgoznom, ami pontossága mellett kellően kis számítási igényű ahhoz, egy átlagos PC-n futtatva alkalmas valósidejű adatfeldolgozásra.

Az új eljárás kidolgozásához részleteiben meg kellett ismernem a nyomás-PA jel-koncentráció térben kifeszülő kalibrációs felületet: 50 mbar lépésekkel 100 és 1000 mbar között végeztem kalibrációs méréseket 1-25000 ppmV tartományon. A mérések során lényegi változtatás nélkül a 15. ábrán található elrendezést használtam, a lézer modulációs és hangolási paramétereit minden esetben úgy állítottam be, hogy azok 180 mbar esetén legyenek optimálisak. Ezek a beállítások egy utasszállító repülőgép repülési magasságában az ideálishoz közeliek.

A VT elektronika dinamikus tartománya nem teszi lehetővé, hogy a teljes koncentrációtartományon azonos beállításokkal végezzünk méréseket: érzékenységet kell állítani, aminek a módját a 8.3 fejezetben mutatom be részletesen. Az érzékenységváltozás 
azt eredményezi, hogy a kalibrációs görbe két (vagy három) szakaszból áll, melyek között nagyjából egy nagyságrendnyi eltérés van meredekségben. A jelfeldolgozás első lépéseként a különböző érzékenység mellett elvégzett méréseket mind a kalibráció, mind valós mérések során az érzékenység különbségével korrigáltam. Az alábbi, 19. ábrán egy 200 mbar nyomáson elvégzett kalibráció eredménye látható, még az érzékenység-különbségek korrigálása előtt.

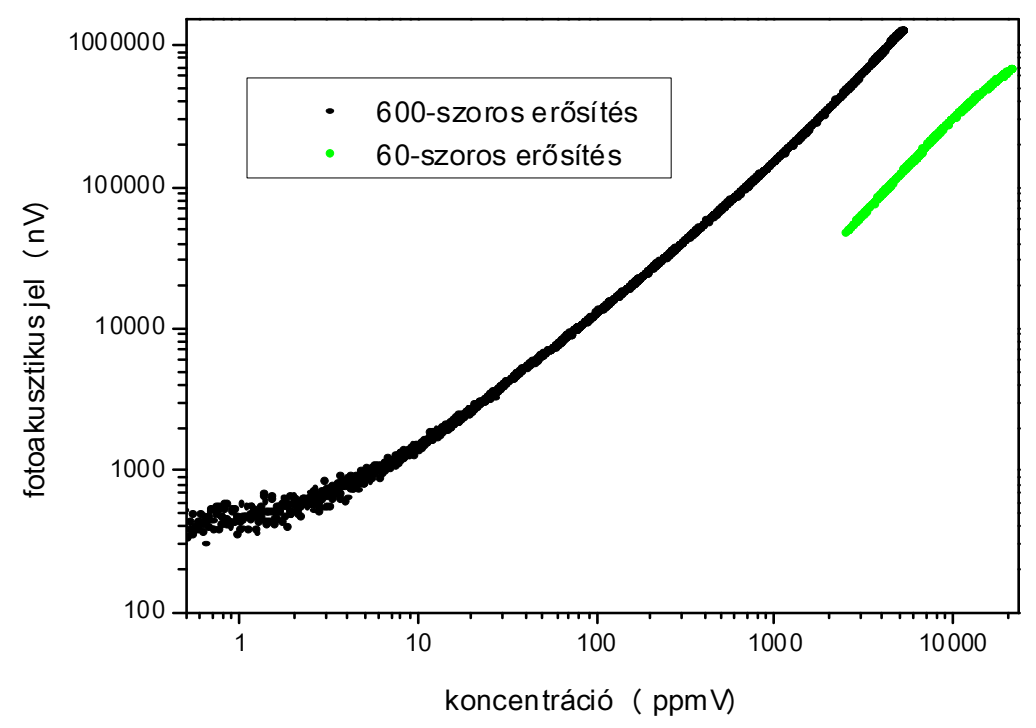

Ábra 20: kalibráció eredménye 200 mbar nyomáson két különböző érzékenység mellett.

\subsection{1. eljárás}

A kapott 3D felület kétváltozós polinomokkal nem volt kellő pontossággal leírható, ezért első próbálkozásként Matlab fejlesztői környezetben elkészítettem egy interpolációs fájlt, amit felhasználva adott nyomás és PA jel esetén meg lehetett határozni a koncentráció értékét. Összehasonlító mérés esetén az eljárást használva a PA mérőrendszerrel meghatározott koncentráció-értékek zajszinten vagy $\pm 2 \%$-on belül megegyeztek a nedvességgenerátor referenciaértékeivel. Az eljárás hibája, hogy optimalizálás után egy átlagos PC esetén egy mérési pont kiértékeléséhez hozzávetőlegesen két másodpercnyi számolási idő volt szükséges, ami két csatorna esetén csak négy, de inkább öt másodpercenkénti méréseket tett volna lehetővé.

\subsection{2. eljárás}

Az említett 50 mbar-onkénti kalibrációs görbéket egyenként polinomokkal közelítettem. Ezekben mind az x értékek (PA jel), mind az y értékek (koncentráció) 4-5 nagyságrendben 
változnak, ezért jó illeszkedést csak magas, 8-12 fokszámú polinomokkal kaptam. Az illesztések elvégzéséhez elkészítettem egy LabVIEW alapú programot, mellyel a mért adatsorra való illesztés könnyedén elvégezhető, a felhasználói felületen lehet állítani mind a fokszámot, az illesztési módszert, és az illesztési algoritmust, az adatok súlyozását, mialatt valós időben lehet összehasonlítani az illesztett görbét a mérttel (Táblázat 4). Erre szükség is volt, mivel szinte mindegyik mérés esetén más-más paraméterekkel kellett elvégezni az illesztést ahhoz, hogy az illesztett görbe a teljes mérési tartományon belesimuljon a mérés zajába. A továbbiakban a meghatározott polinom együtthatókat használtam a kalibrációs felület jellemzésére, hiszen az ezek által definiált a polinomok feszítik ki azt.

$\mathrm{Az}$ adatok kiértékelése során első lépésként a mért PA jelből a kalibrációs polinomokat használva minden egyes nyomáson meghatároztam, hogy az adott nyomáson az adott PA jelhez mekkora koncentráció tartozna. Ennek eredményeként kaptam egy két oszlopból álló adattáblát, amelynek az első oszlopa a nyomásértékeket, a második pedig a pillanatnyi PA jelhez a különböző nyomásokon tartozó koncentráció értékeket tartalmazta. Ebből az adattáblából kettős-köbös interpolációt alkalmazva lehet meghatározni az aktuális nyomáshoz és PA jelhez tartozó koncentrációkat.

\begin{tabular}{ccc}
\hline \hline módszer & algoritmus & súlyozás \\
\hline $\begin{array}{c}\text { legkisebb abszolút eltérés } \\
\text { legkisebb négyzetek } \\
\text { eltérése } \\
\text { kettős négyzetes }\end{array}$ & SVD & konstans 1 \\
& Givens2 & PA jel \\
& Householder & PA jel négyzete \\
LU dekompozíció & PA jel reciproka \\
Cholesky & PA jel négyzetgyöke \\
\hline \hline
\end{tabular}

Táblázat 4: A kalibrációs görbék illesztése során választható paraméterek. 
Összehasonlító mérés során az előző algoritmushoz hasonló pontossággal egyezett meg a PA rendszerrel meghatározott koncentráció és a nedvességgenerátor referenciaértéke a nyomástól függetlenül (Ábra 21).
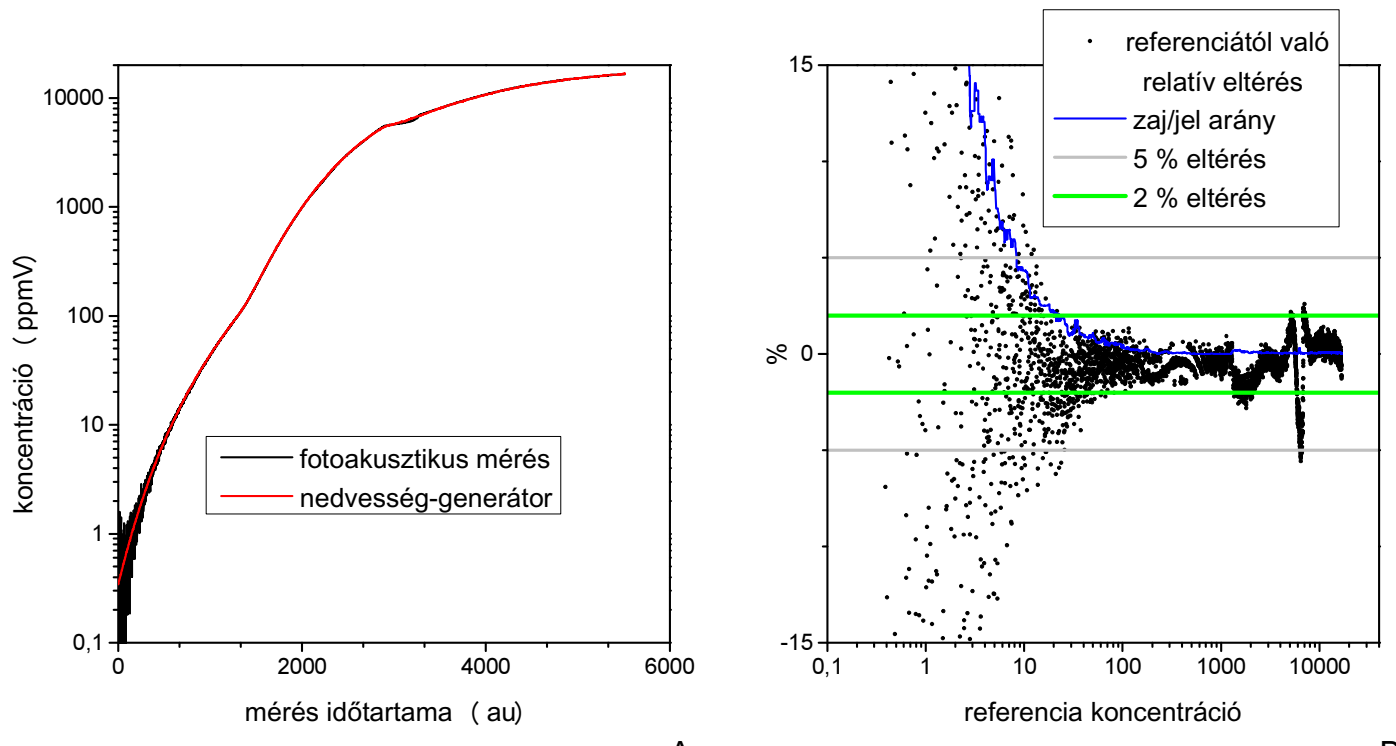

A

Ábra 21: A kalibrálás tesztjének eredménye.

A kiértékelési időben viszont sikerült jelentősen előrelépni: ugyanazon a PC-n futtatva néhány ms elegendő egy mért adatpárosból (PA jel, nyomás) koncentráció meghatározásához, így két csatornán is lehet alkalmazni valós idejü mérések során.

A kapott kalibrációs görbéket feldolgozva megállapítottam, hogy nem szükséges 50 mbaronként elvégezni a kalibrálásokat (nyomásonként másfél-két nap mérési idővel), hanem ritkábban is elegendő, pl.: $80,130,150,200,280,370,500,650,800,970$ mbar értékeknél. Továbbá a nyomásstabilizáló rendszer gyorsításával egy kalibráció alatt ciklikusan is lehetett léptetni a nyomást, aminek eredményeként háromszor másfél-két napos méréssel, praktikusan egy hét alatt el lehet végezni a rendszer kalibrációját. Az 50 mbar-onkénti kalibráció nyomásonként mindössze egyszeri ellenőrzéssel mintegy három hónapot vett igénybe.

Egy, a kalibráció alatt ciklikusan léptett nyomáson való mérés kiértékelése során meghatároztam különböző koncentrációkon a rendszer érzékenységét a nyomás függvényében (Ábra 22). 


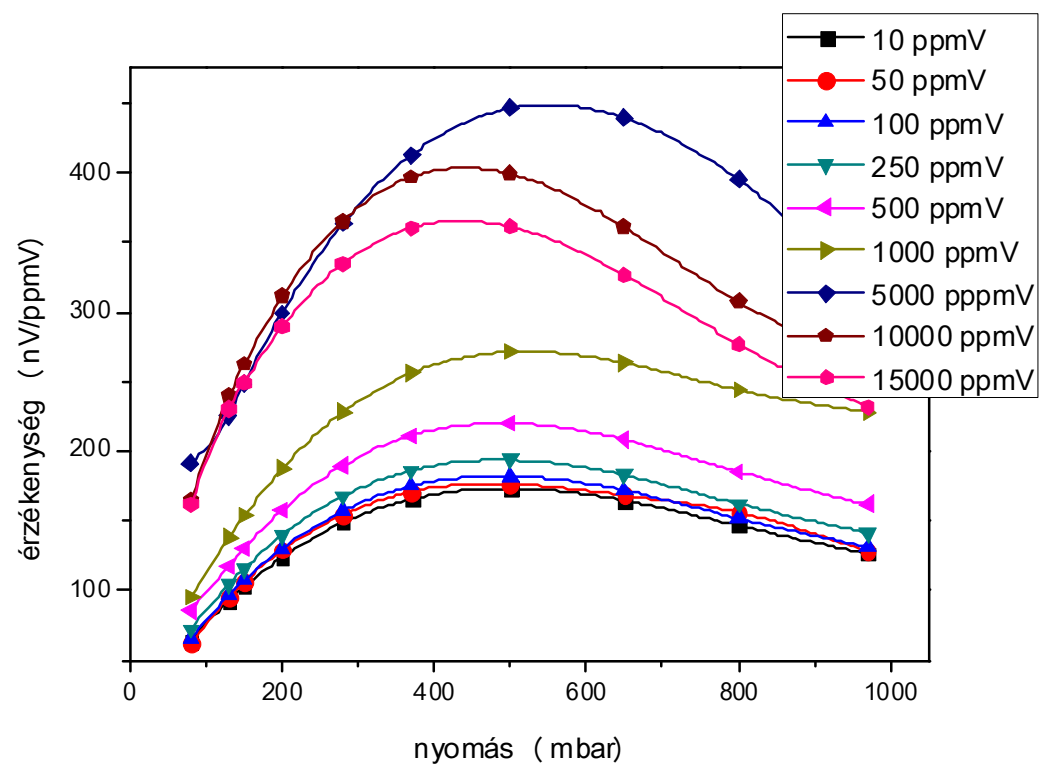

Ábra 22: a mérörendszer érzékenysége különböző koncentrációkon a nyomás függvényében.

Az újonnan kidolgozott eljárás hasonlít a korábban alkalmazotthoz: abban egy nyomáson mért kalibrációs görbe és egy koncentráción mért nyomásfüggés alapján történt a koncentráció meghatározása. Ez az eljárás akkor múködne pontosan, ha a 22. ábrán látható görbék egymásnak konstansszorosai lennének. Azonban jól látható, hogy ez a feltétel nem teljesül: a rendszer érzékenységének a nyomásfüggése jelentős mértékben változik a koncentrációval, amiből következik, hogy a korábbi jelkiértékelési eljárás - ami az ábra görbéi közül csak egyet vett figyelembe - szisztematikus hibával volt terhelt.

\section{3 Összegzés}

Kidolgoztam egy új kalibrálási és jelkiértékelési eljárást, amely a nyomás-koncentráció-PA jel térben kifeszülő kalibrációs felület kísérleti meghatározásán alapul az alábbiak szerint: különböző, de konstans nyomásokon kell meghatározni a koncentráció függvényében a PA jel nagyságát. A különböző nyomásokon kapott kalibrációs görbéket felhasználva a pillanatnyi nyomás és a PA jel nagyságából egy interpolációs eljárással lehet meghatározni a koncentráció pontos értékét. A bemutatott eljárás alkalmazásával, a PA mérőrendszerrel mért koncentrációk zajszint $\pm 2 \%$-on belül megegyeznek a kalibrálás során alkalmazott referenciaműszer értékeivel 100-1000 mbar nyomás és 0,5-25000 ppmV koncentrációtartományon belül, szemben a korábban alkalmazott eljárással, amelynek pontossága ugyanilyen körülmények között (a nyomástól és a koncentrációtól függően) akár egy 
nagyságrenddel is rosszabb volt. Korábban, a méréseknek ezt a pontosságát a változó nyomás mellett nem lehetett megvalósítani. További előnye az új eljárásnak, hogy az adatok kiértékelése néhány milliszekundum időt vesz igénybe mérési pontonként, így valós idejü jelkiértékelésre is lehetőség van. [117] 


\section{8 Új mérőrendszer tervezése és építése független laboratóriumi és repülőgépes összehasonlító mérésekhez}

A megnövelt precizitású hullámhossz-beállítási és megnövelt pontosságú jelkiértékelési eljárások kifejlesztése után a szerzett tapasztalatokra alapozva elkészítettem a műszernek egy új változatát, amelyet független laboratóriumi és repülőgépes mérési kampányok során teszteltem, hogy igazoljam a rendszernek nem csak a megbízhatóságát, hanem a pontosságát is.

\subsection{A mérőrendszer felépítése}

Az új mérőrendszer tervezésekor úgy volt, hogy az az EUFAR/DENCHAR projekt keretein belül részt vesz egy 6-12 hónapos megbízhatósági teszten, amelynek keretein belül napi rendszerességgel végzett volna méréseket kutató-repülőgépre telepítve, repülések során. Végül a repülőgépek üzemeltetésére vonatkozó jogszabályi változtatások miatt ez a hosszú távú teszt elmaradt. A tervezett mérések során csak a mérési eredményeket kaptuk volna meg, a műszert pedig a repülőgép személyzete üzemeltette volna, és csak igen komoly probléma esetén lehetett volna hozzáférni, mivel a mérések bázisa egy német katonai támaszponton lett volna. Ennek megfelelően a hosszú távú megbízhatóság és az egyszerū üzemeltethetőség voltak a legfontosabb követelmények, amelyeknek a múszernek meg kellett felelnie, természetesen a megfelelő pontosságú és precizitású mérések végzése mellett.

A repülőgépen való üzemeltetés során 28 VDC tápellátás áll rendelkezésre, ezért a korábban használt 220 VAC meghajtásról üzemelő kamra- és mintavevő fútést újra kellett terveznem és el kellett készítenem. Mindhárom esetben szilikonszigetelésû árnyékolt ellenálláshuzalt választottam, melyekre a VT elektronika által meghajtott szilárdtest-relékkel kapcsoltam tápfeszültséget a fútéshez. A VT elektronika önmagában 28 VDC tápfeszültségről üzemel, ezért ennek a meghajtása alapvetően nem jelentett problémát. A megbízhatóság javítása érdekében viszont elhelyeztem a múszerben egy DC-DC konvertert (Phoenix Contact QUINTPS/24DC/24DC/5-2320034), aminek a feladata a repülőgép tápfeszültségében esetlegesen fellépő zavarok, pillanatnyi kimaradások kiküszöbölése volt.

A mérőrendszer strukturális felépítésében megmaradtam a korábbi felépítésnél, azaz a rendszer egy vezérlőelektronikából, egy kétszeresen hőmérséklet-stabilizált diódalézerből, két 
differenciális PA kamrából, nyomásmérőkből, tömegáramlás-szabályozókból és fútött mintavevő csövekből állt (Ábra 23).

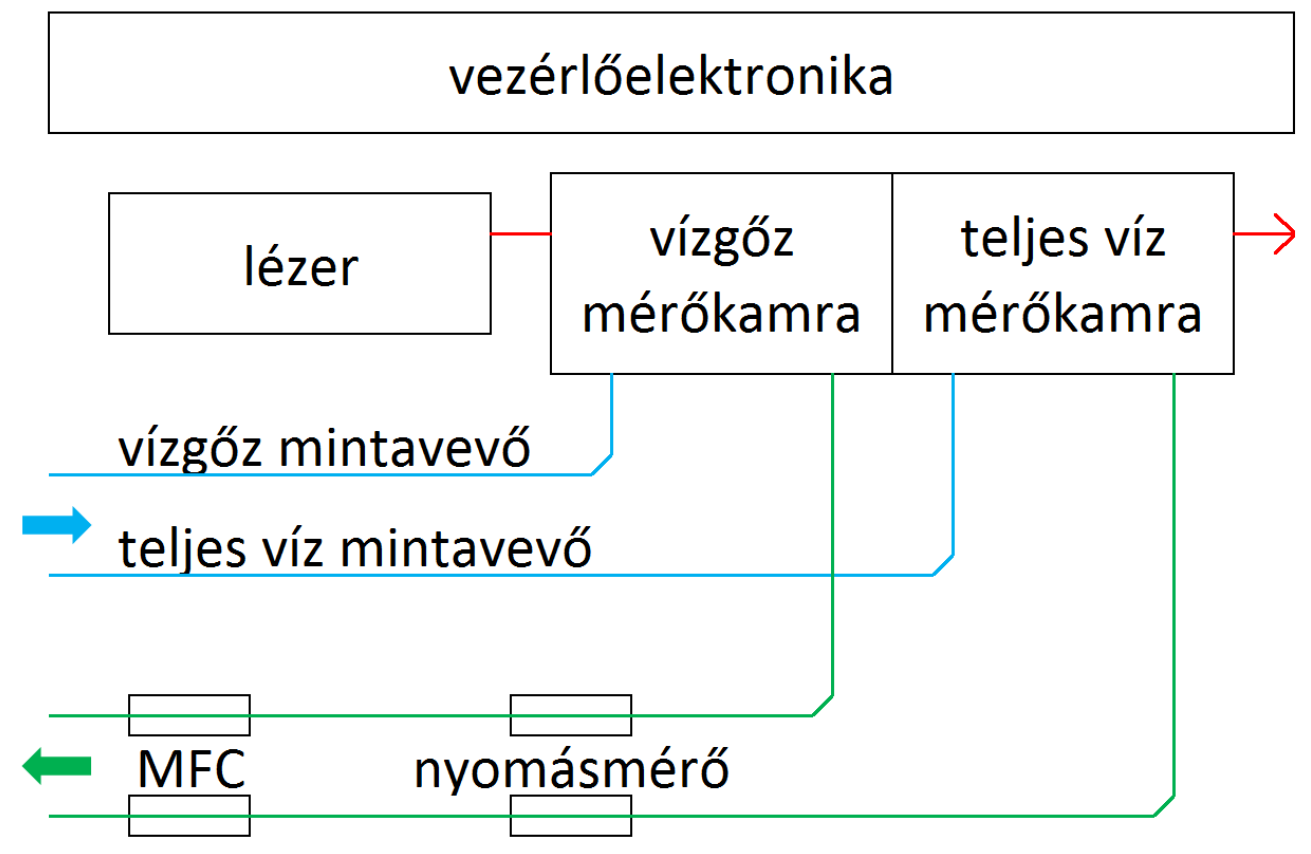

Ábra 23: Az újonnan elkészített mérörendszer felépitése.

A mérőrendszert egy 19 " széles $3 U$ magas és 18 " mély szabványos rack-ben helyeztem el. A rendszer teljes tömege $15 \mathrm{~kg}$.

\subsection{Elnyelési vonal váltása}

Az új mérőrendszerben nem a korábban használt 1371, hanem az 1392,5 nm hullámhosszú $\left(3,67 \times 10^{-5} \mathrm{ppm}^{-1} \mathrm{~m}^{-1}\right)$ elnyelési vonalat használtam [100] (Ábra 24). Az elnyelési vonalak lényegileg azonos erősségűek, de az új elnyelési vonalnál nagyjából kétszeres teljesítményű lézerek is elérhetőek, amelyek használatával az 5 . egyenlet értelmében kétszeres érzékenységgel lehet méréseket végezni. Most már a CARIBIC2 rendszerben is erre az elnyelési vonalra hangolt lézert használunk. 


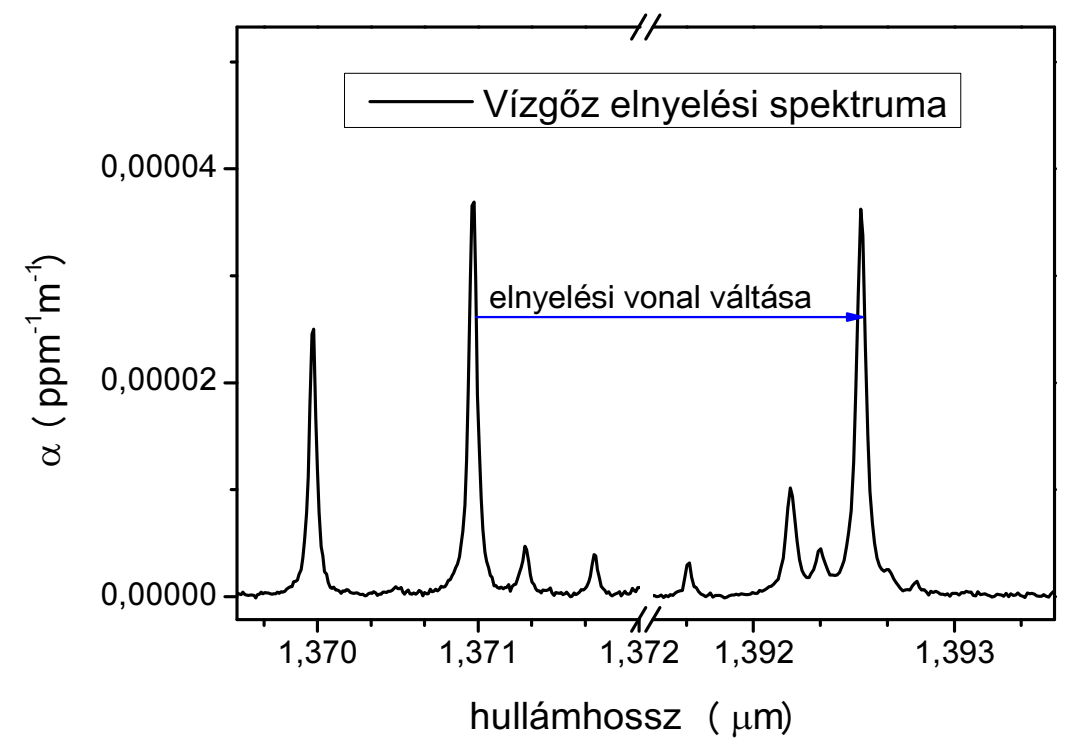

Ábra 24: Vízgőz spektrumának részlete [100] és az elnyelési vonal váltása.

\section{3 Érzékenységváltás}

A VT elektronika dinamikus tartománya nem elegendő légköri vízgőz-koncentráció méréséhez, ezért különböző érzékenység-állapotokat kellett definiálni, melyek közötti váltás automatizáltan végrehajtható. Erre a célra egyrészt az elektronika is lehetőséget biztosit, benne a mikrofon erősítése 600-és 6000-szeres értékek között változtatható. Másik lehetőség a modulációs frekvenciának a megváltozatása, hogy ne a kamra rezonanciagörbéjének a maximumhelyénél végezzük a méréseket, hanem egy olyan frekvencián, ahol az érzékenység hozzávetőlegesen egy nagyságrenddel kisebb.

Mérések során a 600-szoros és a 6000-szeres erősítések között jel/zaj arányt tekintve nem lehet különbséget tenni; vízgőz-koncentráció- mérés során az elérhető nagyobb dinamikus tartomány érdekében csak 600-szoros erősítés mellett végeztünk méréseket. Magas koncentrációk esetén a rendszer érzékenységét a modulációs frekvencia növelésével, egy nagyságrenddel kellett csökkenteni. Javaslatomra a Videoton Zrt. Fejlesztési osztályán átalakították a mikrofonerősitőt 60 és 600-szorosra. Ezzel az átalakítással három, egymástól érdemben különböző érzékenységi állapotot lehet definiálni: 
1. 600-szoros erősítés, rezonáns moduláció mellett

2. 60-szoros erősítés rezonáns moduláció mellett

3. 60-szoros erősítés offrezonáns moduláció mellett.

A harmadik érzékenységi állapotra az eddigi tapasztalatok szerint csak a természetben igen valószínǔtlen, 40000 ppmV feletti koncentrációk lenne szükség. Ezzel a változtatással azonban az 1. és 2. érzékenységek mellett kapott kalibrációs görbék könnyebben hozhatóak fedésbe egymással, valamint becslés szerint 400000 ppmV-re sikerült kiterjeszteni a felső detektálási küszöböt. Ugyanakkor a jelenlegi konfiguráció mellett a legmagasabb vizsgálható koncentráció 80000 ppmV körül van, amit a csövek falán való kondenzáció limitál.

A mérések során az egyes érzékenységi állapotok között a PA jel nagyságát figyelve a rendszer automatizáltan vált. A fel-és leváltások között egy hiszterézist vezettem be, hogy a váltási limit határán ingadozó jel esetén elkerüljem a gyakori érzékenység váltásokat.

\subsection{A mérőrendszer szoftvere}

\subsubsection{Az elektronikán futó szoftver}

Az elektronikán futó szoftver feladata az egyes mérési rutinok, fent bemutatott érzékenységi állapotok definiálása, az azok közötti váltás szervezése, a rendszer állapotának monitorozása. Ennek a programnak csak definiáltam a működését, a programkódot Varga Attila (Hilase Kft.) készítette el.

További részletezés nélkül a program funkciói:

- lézer hőmérsékletének munkapontra való beállítása és stabilizálása,

- lézer hullámhosszának pontos beállítása,

- lézer meghajtása, modulálása,

- mérés végzése,

- érzékenységek közötti váltás,

- PA kamrák és mintavevő csövek hőmérsékletének stabilizálása,

- nyomásmérők adatainak mérése,

- önellenőrzés,

- adatok továbbítása soros porti (RS232) kommunikációval. 
Az elektronika az adatokat broadcast üzemmódban továbbítja soros porton keresztül, azaz nem kér visszajelzést, hogy az adott üzenet rögzítésre került-e vagy sem. Ez a kommunikációs protokoll egyszerū kezelhetősége miatt igen előnyös.

\subsubsection{Az adatgyưjtő számítógépen futó szoftver}

$A z$ adatgyưjtő számítógépen futó szoftvernek, melyet LabVIEW környezetben készítettem el (Ábra 25) három funkciója van:

- A mért adatokat gyűjti soros porti kommunikációval.

- A mért adatokat feldolgozza és megjeleníti. A kapott nyers adatok többsége részben kettes komplemens számábrázolása, részben, kalibrálatlan volta miatt nehezen értelmezhető, ezeket a program átalakítja szokványos mértékegységrendszerbe (SI, valamint Celsius fok hőmérséklet esetén). Ezen felül a rendszer hibaüzeneteit, figyelmeztetéseit is dekódolja, megjeleníti. Természetesen a korábban bemutatott eljárással mindkét mérőkamrában meghatározza az aktuális koncentrációt is.

- A nyers, és a feldolgozott adatokat összesen négy fájlba menti: az első a teljesen nyers adatsor. A második öt oszlopot tartalmaz: idő, koncentráció1, koncentráció2, nyomás1, nyomás2. A harmadik az összes feldolgozott adatot tartalmazza. A negyedik pedig a figyelmeztetések, hibaüzenetek log fájlja. 


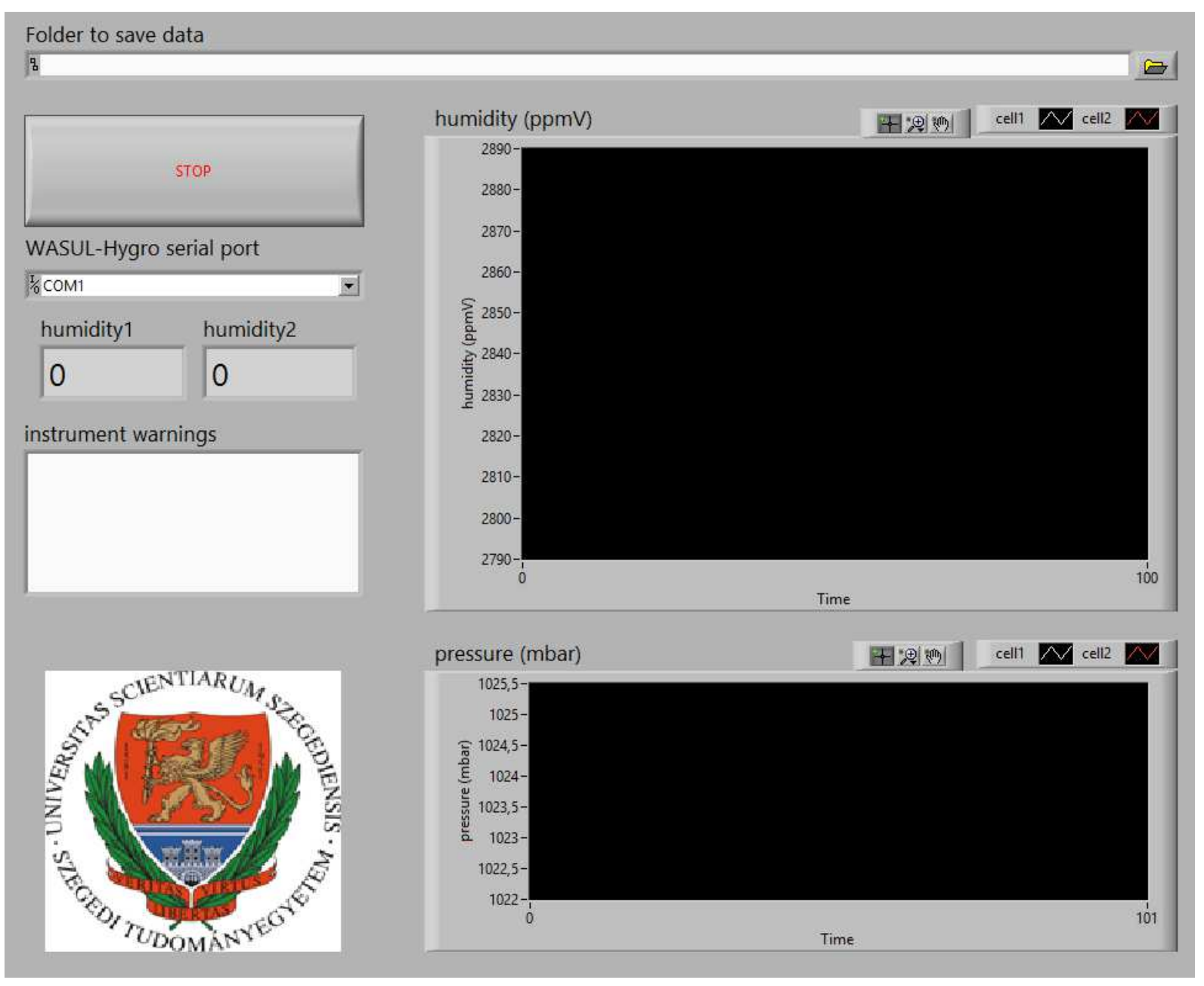

Ábra 25: Az adatgyüjtő és feldolgozó program felhasználói felülete. /Folder to save data: adatok mentésének könyvtára, humidity: nedvességtartalom, pressure: nyomás, WASUL-

Hygro serial port: használandó soros port, instrument warnings: figyelmeztetések/

\subsection{Laboratóriumi összehasonlító tesztek}

\subsubsection{A mérési környezet}

Az EUFAR/DENCHAR projekt keretein belül a fejlesztések alatt több alkalommal lehetőségem nyílt a Jülichi Kutatóközpontban független összehasonlító méréseket végezni. A méréseket az ESF ${ }^{27}$ légkör szimulációs kamránál [118] végeztem el. Ez a kamra szolgál többek között a MOZAIC projektben használt vízgőz és ózon koncentráció mérő eszközök kalibrálására is. $A$ kamra $80 \times 80 \times 80 \mathrm{~cm}$-es belső hasznos térfogattal rendelkezik, amiben a nyomást 1001000 mbar, a hőmérsékletet 200-300 K, a relatív páratartalmat pedig 2-95 \% tartományon lehet változtatni. A mérőkamrában két referenciaműszer van elhelyezve, egy egyedi Lyman- $\alpha$

\footnotetext{
${ }^{27}$ Environmental Simulation Facility
} 
lumineszcencia elvű a kis koncentrációk méréséhez (3\% pontosság 1-1000ppmV tartományon), valamint egy General Eastern D1311R tükrös harmatpontmérő $(0,5 \mathrm{~K}$ pontosság) a magasabb koncentrációkhoz. A mérések során egy $1 / 8$ " külső átmérőjű fútött rozsdamentes acél csövön keresztül mintavételeztem a vizsgált levegőt. Az SZTE2 rendszer két mintavevőjét egy tee csatlakozóval közösítve kapcsoltam az $1 / 8$ "-es mintavevőhöz. A szimulációs kamrában a mintavevő cső vége, valamint a referenciaműszerek egymáshoz közel voltak elhelyezve, hogy a térbeli anizotrópiák minél kevésbé befolyásolják a méréseket. Ugyanakkor gyorsan változó körülmények esetén, amikor a szimulációs kamra termodinamikai értelemben eltávolodik kvázisztatikus állapotától, a kis távolság, valamint a mintavevő csőben megtett út így is számottevő eltérésekhez vezetett. A számos összehasonlító mérés közül kettőt emelnék ki, melyeket 2011 májusában végeztem el.

\subsubsection{Mérési eredmények}

A mérések során semmilyen rendellenességet nem tapasztaltam a rendszerrel kapcsolatban sem hardveresen, sem szoftveresen. A mérések zaja mindig a kalibráció alattival volt megegyező. A két mérőkamrával 1\%-on vagy zajszinten belül azonos adatokat mértem.

Az első esetben (Ábra 26) a szimulációs kamrában lévő mintavevő cső fútése csak a mérés alatt lett bekapcsolva $\mathrm{t}=0,46$ nap körül, ami eredményeként a cső faláról deszorbeálódó vízgőz következtében nagyjából $t=0,51$ nap-ig jelentős a referencia-múszerektől való eltérés. $t=0,55$ nap után pedig a relatív eltérés - nyomástól függetlenül - lényegileg $5 \%$ alatt volt. A nagy eltéréssel terhelt mérésrész alatt volt az ESF kamrában a legalacsonyabb, 3-4 ppmV körüli koncentráció. Ezt jól mutatja a 26. B ábra is, amelyen a referencia-adatok függvényében, a nyomást színnel kódolva ábrázoltam az SZTE2 rendszerrel mért adatokat: az ideális 1:1 egyenestől való eltérés 10 ppmV alatt vált számottevővé. Ezt a szakaszt a számszerűsített összehasonlítás során nem is vettem figyelembe.

A második esetben (Ábra 27) lényegileg két nyomáson történtek a mérések, viszont a kis, 10 ppm alatti koncentrációk esetén is sikerült összehasonlítható méréseket végezni: $A$ mért értékek közötti relatív hiba végig $5 \%$ alatt maradt, csak az 5 ppmV alatti tartományon elsősorban a mérés zaja miatt - volt ennél némileg magasabb. 
A teljes mérési kampány számszerűsített eredményeit (relatív eltéréstartományok intervallumai, Pearson korreláció, keresztábrázolás meredeksége) az 5. táblázatban foglaltam össze.
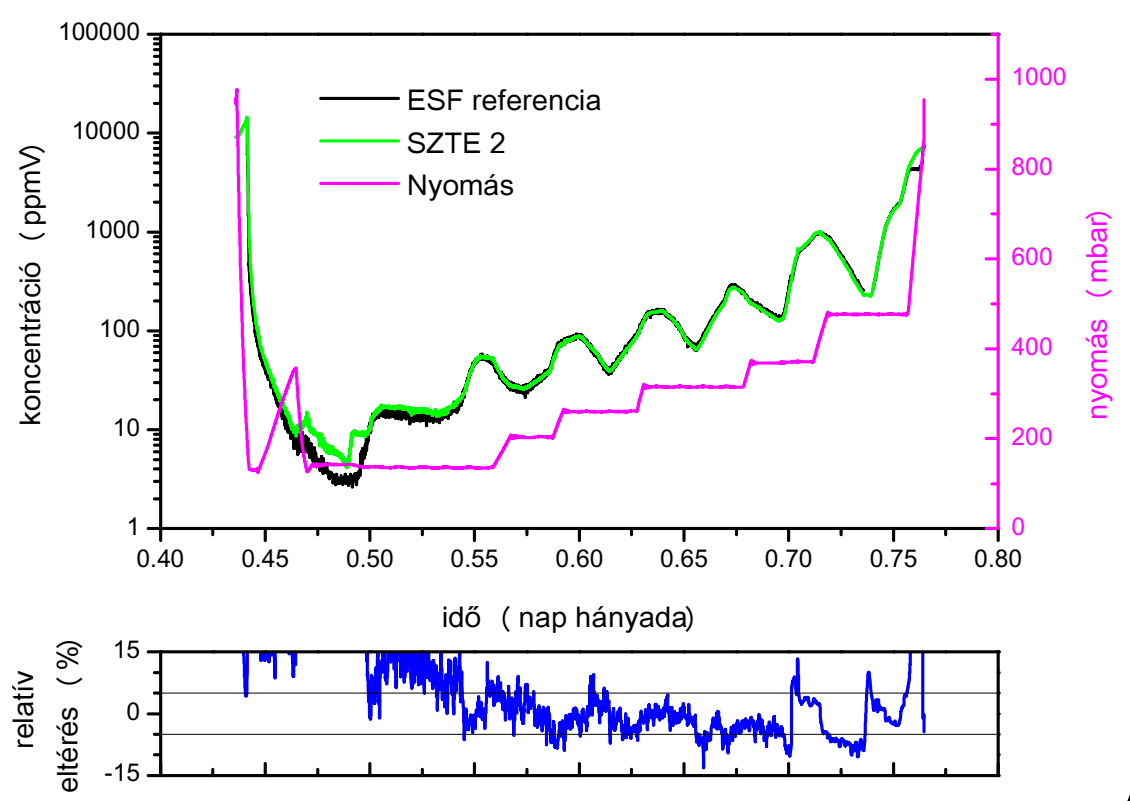

A
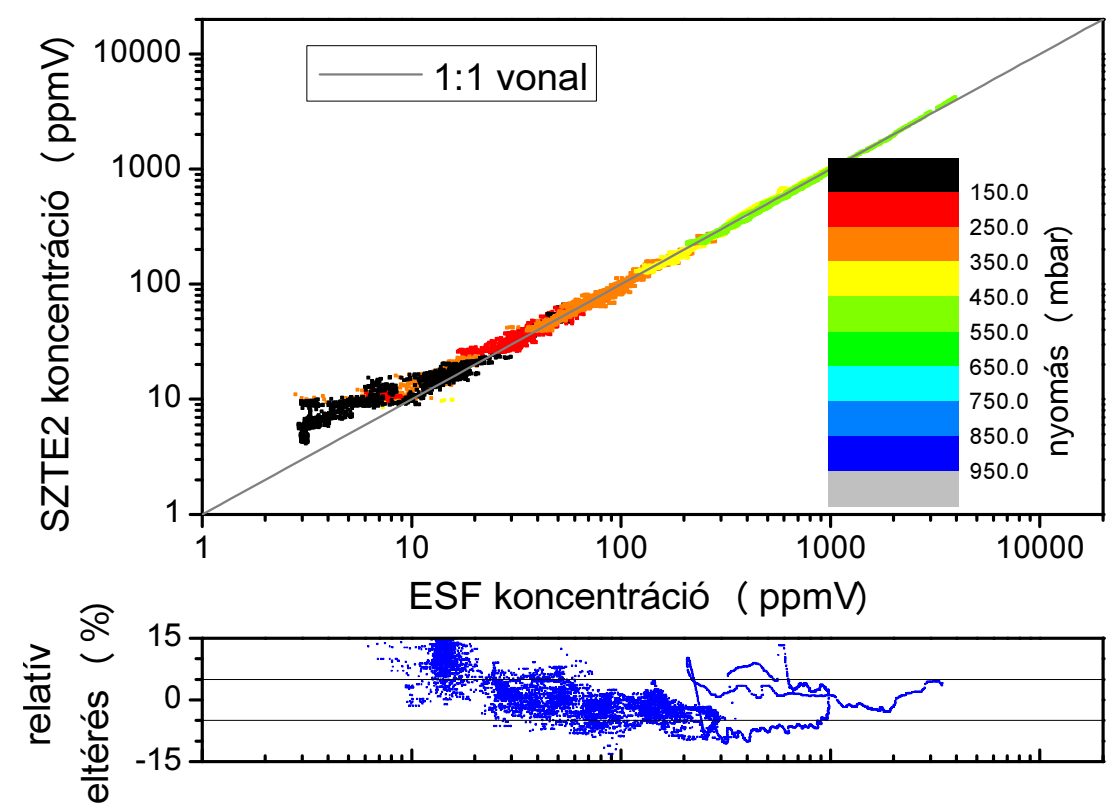

B

Ábra 26: Összehasonlító mérés az ESF kamrával (2011.05.06.) 

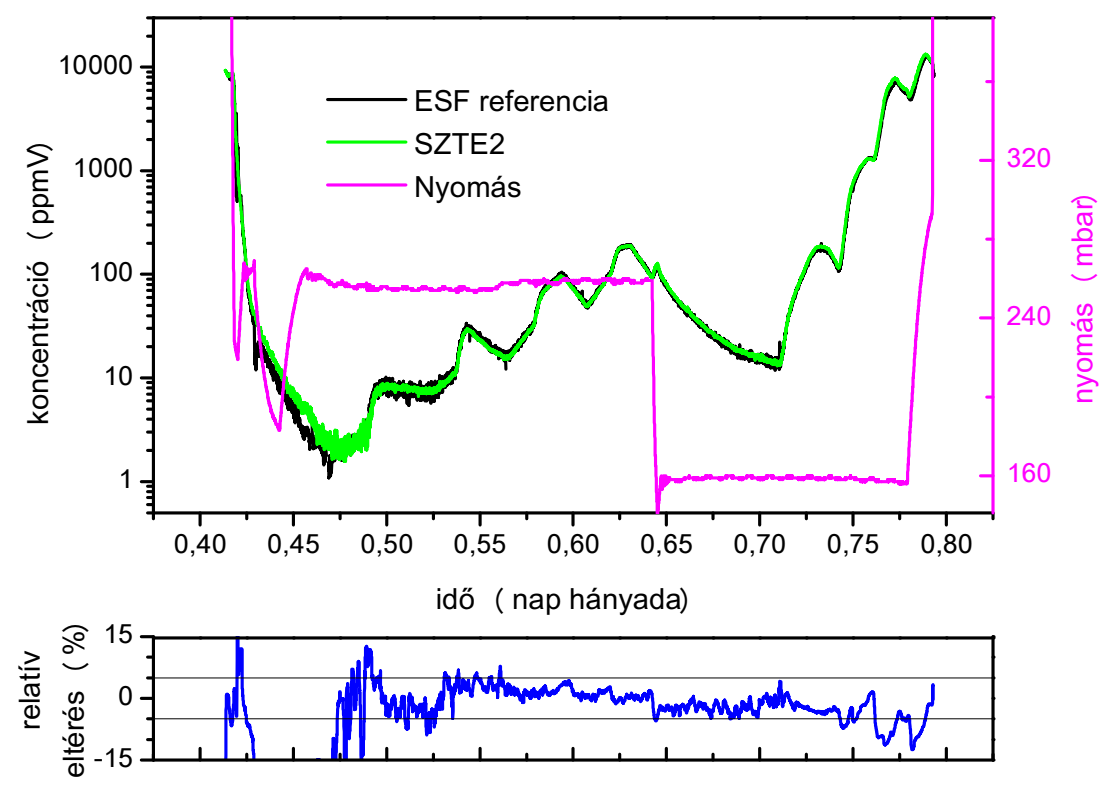

A
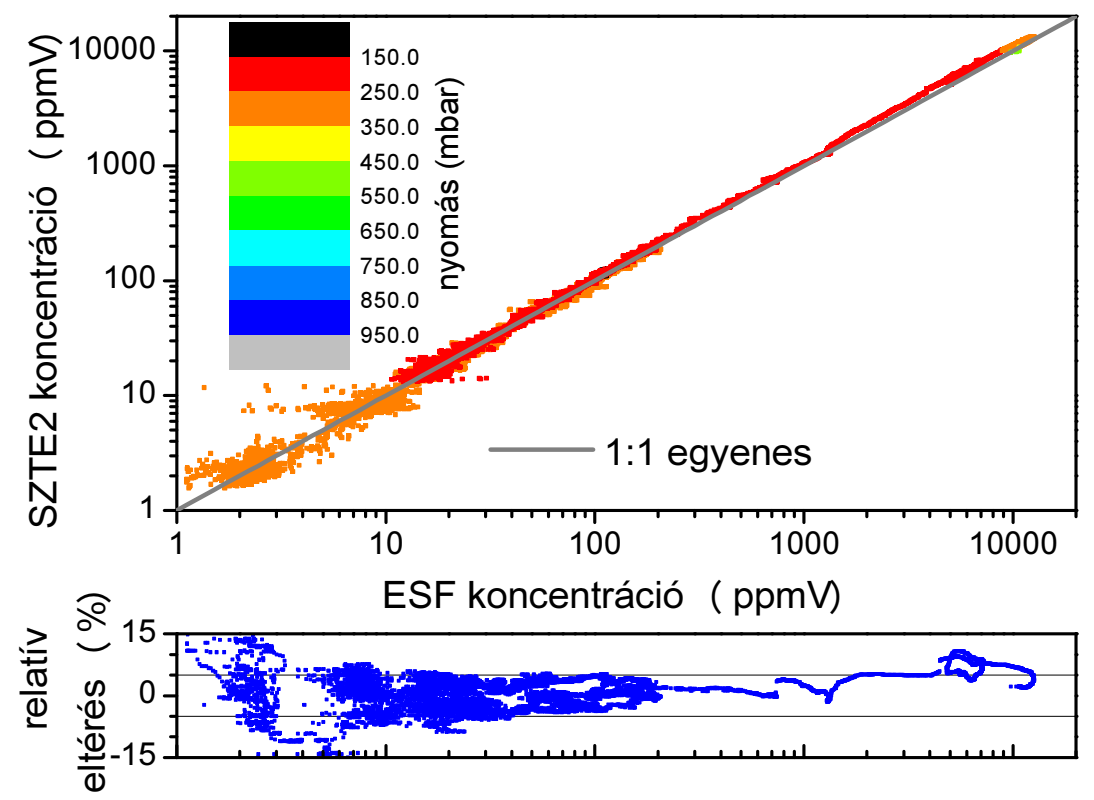

B

Ábra 27: Összehasonlító mérés az ESF kamrával (2011.05.04.) 


\begin{tabular}{cccccc}
\hline \hline \multirow{2}{*}{$\begin{array}{c}\text { Referencia- } \\
\text { müszer }\end{array}$} & \multicolumn{2}{c}{$\begin{array}{c}\text { Referenciamüszerektől való relatív } \\
\text { eltérés tartományok }(\mathrm{ppmV})\end{array}$} & $\begin{array}{c}\text { Pearson } \\
\text { korreláció }\end{array}$ & $\begin{array}{c}\text { keresztábrázolás } \\
\text { meredeksége }\end{array}$ \\
\cline { 2 - 4 } & $\begin{array}{c}\text { zajszinten } \\
\text { belül }\end{array}$ & $2 \%$ & $5 \%$ & & \\
\hline ESF kamra & $<150$ & $200-750$ & $15-12000$ & 0.99948 & 1.015 \\
WS-CRDS & $<300$ & $1500-4000$ & $100-4000$ & 0.99986 & 1.047 \\
FISH & $<20$ & NA & NA & 0.9965 & 0.86 \\
\hline \hline
\end{tabular}

Táblázat 5: Az SZTE2 rendszer összehasonlitása referenciamüszerekkel laboratóriumi és repülőgépes mérési kampányok során.

\subsection{Repülőgépes összehasonlító tesztek}

\subsubsection{A mérési kampány}

Szintén az EUFAR/DENCHAR projekt keretében 2011 május 24. és június 1. között részt vettem egy repülőgépes mérési kampányban [119], amelynek az elsődleges célja repülőgépes vízgőzkoncentráció- mérő- rendszerek összehasonlítása volt. A mérések bázisa a Hohn-i Katonai Repülőtér volt, a platform pedig egy Learjet 36A repülőgép volt, melyet a GFD GMBH (Hohn, Németország) üzemeltetett. A műszerek telepítését és repülések alatti üzemeltetését az Enviscope GMBH (Frankfurt, Németország) végezte el.

A mérésekre észak-Európa légterében (Ábra 28) került sor egészen 13 km-es repülési magasságig. 


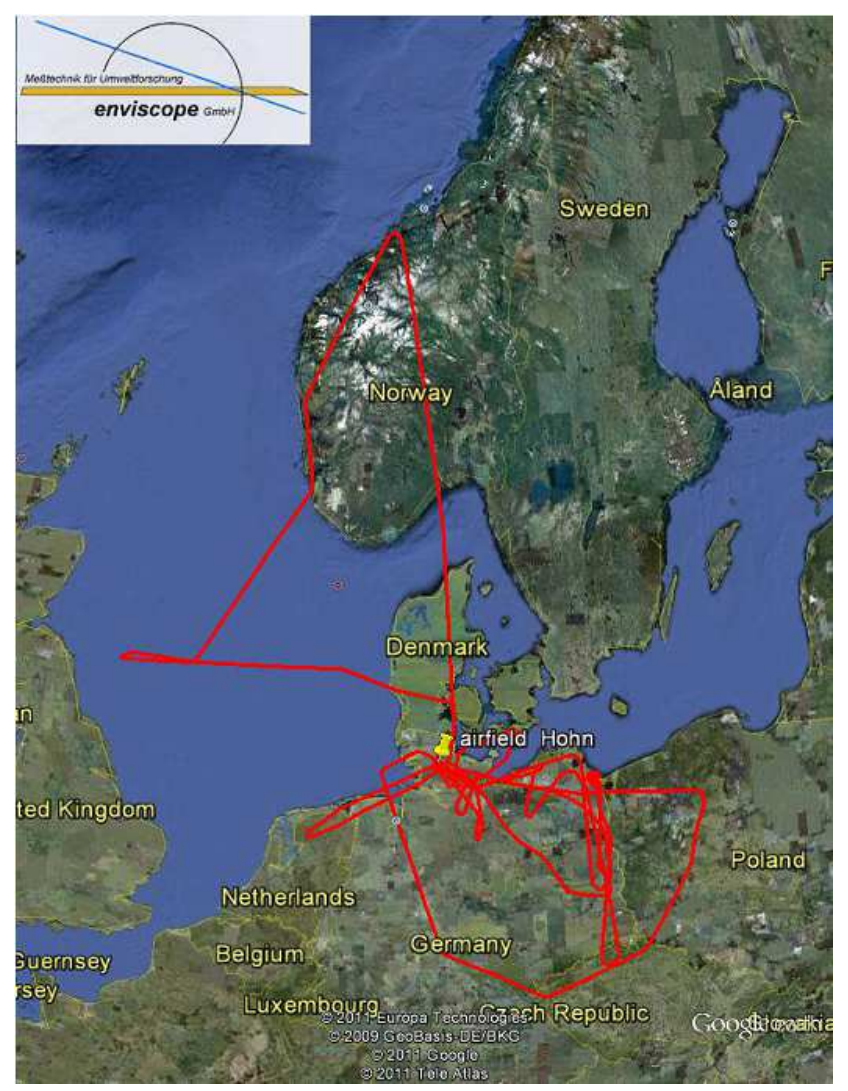

Ábra 28: A repülési útvonalak a mérési kampány során [120].

A kampány során számos múszert hasonlítottunk össze, azonban az adatkezelési protokoll szerint csak két múszerrel való összehasonlítás eredményeit mutathatom be:

Az első műszer a Jülichi kutatóközpontban kifejlesztett Lyman- $\alpha$ lumineszcencia elvű FISH ${ }^{28}$ (1Hz mérési idő mellett 0,2-0,15 ppmV zajszint 3 ppmV koncentráció esetén; 0,13-1500 ppmV dinamikus tartomány) [33, 77]. A müszer sajátossága, hogy pontos múködéséhez rendszeresen kalibrálni kell, amit egy saját fejlesztésű telítés-hígítás elvű nedvességgenerátor és egy tükrös harmatpontmérő (MBW DP30) segítségével végeznek el minden repülés előtt és után.

A második műszer egy kereskedelmi forgalomban kapható (PICARRO G2401-m, Picarro, Inc.) hullámhossz szkennelt CRDS (WS-CRDS ${ }^{29}$ ) [121, 122] mérési technikára alapuló műszer, amely vízgőz-koncentráció mellett metán, széndioxid és szénmonoxid koncentrációt is mér. 2,5 s mérési idő mellett a múszer pontossága 10 ppmV 100 ppmV esetén, valamint 200 ppmV

\footnotetext{
${ }^{28}$ Fast In-situ Stratospheric Hygrometer

${ }^{29}$ Wavelength-Svcanned Cavity Ringdown Spectroscopy
} 
10000 ppmV esetén, míg a precizitása 4 ppmV vagy $1 \%$; ugyanakkor a rendszer 50 ppmV koncentráció alatti megbízhatósága kérdéses. A kampány során a műszert kalibrálták a FISH kalibrációs referenciájához. A múszerrel kapcsolatban fontos információ, hogy egy automatizált kalibrációs rendszerrel kiegészítve a IAGOS projekt üvegházhatású gáz mérőcsomagjának az alapját képezi.

A PA múszer két mintavevője logisztikai okokból ismét közösítve lett egy tee csatlakozóval. Valamint mindhárom múszer más-más mintavevőre lett csatlakoztatva:

\begin{tabular}{|c|c|c|}
\hline múszer & mintavevő & $\begin{array}{c}\text { mintavételezett } \\
\text { víztartalom }\end{array}$ \\
\hline SZTE2 & hátrafelé néző & vízgőz \\
\hline FISH & előre néző & teljes víz \\
\hline WS-CRDS & $\begin{array}{c}\text { előre néző Rosemount } \\
\text { TAT }\end{array}$ & $\begin{array}{c}\text { vízgőz és cseppfolyós } \\
\text { felhőtartalom }\end{array}$ \\
\hline
\end{tabular}

Táblázat 6: A repülögépes kampány során az egyes müszerekhez használt mintavevők.

A különböző mintavevők használatával felhők jelenlétekor más-más koncentrációkat lehet mérni, ezért azokat az időszakokat kihagytam a számszerűsített összehasonlításból. A felhők jelenlétének a meghatározásához a repülőgépre telepített különböző, fényszórás detektálásán alapuló részecskeszámláló és méreteloszlás-mérő műszerek eredményeit lehetett felhasználni. Ezt a Mainz-i Egyetem munkatársai tették meg.

A mérések során a központi adatgyújtő számítógép számos alkalommal lefagyott, ami alkalmanként 5-10 perces adatvesztést okozott.

A kampány során összesen négy repülésre került sor, amelyekből az első kettő alatt a FISH kismértékű szivárgás miatt pontatlanul mért, így vele két repülésnyi, összesen 3,6 órányi, míg a WS-CRDS műszerrel négy repülésnyi, összesen 8,2 órányi adat állt rendelkezésre számszerű összehasonlításhoz. 


\subsubsection{Eredmények}

A laboratóriumi mérésekhez hasonlóan a mérések során semmilyen rendellenességet nem tapasztaltam a rendszerrel kapcsolatban sem hardveresen, sem szoftveresen. A mérések zaja mindig a kalibráció alattival volt megegyező. A két mérőkamrával 1\%-on vagy zajszinten belül azonos adatokat mértem.

$\mathrm{Az}$ adatok kiértékelése során azokat a paramétereket határoztam meg, melyeket a laboratóriumi összehasonlítás során is; az eredményeket azokkal együtt az 5. táblázatban foglaltam össze.

A mérések során 70-80 ppmV koncentráció felett nyomástól függetlenül szinte minden esetben 5\%-os vagy jobb volt az egyezés a WS-CRDS műszerrel (Ábra 29). A FISH-sel való összehasonlítás során az egyezés zajszinten vagy 25\%-on volt belül (Ábra 30). A kapott eredmények keresztábrázolása során a FISH-t összevetve akár a WS-CRDS, akár az SZTE2 rendszerrel hasonló, 0,85 körüli meredekséget kapunk, ami azt sugallja, hogy a FISH méréseit valamilyen, fel nem derített körülmény, akár kismértékű maradék szivárgás, akár a mintavevő által okozott hatás befolyásolta. A kis koncentrációk esetén az SZTE2-rendszerrel mértadatok alapvető helyességét a jelentős relatív eltérés ellenére a Pearson korreláció 0,9965-es értéke mutatja. 

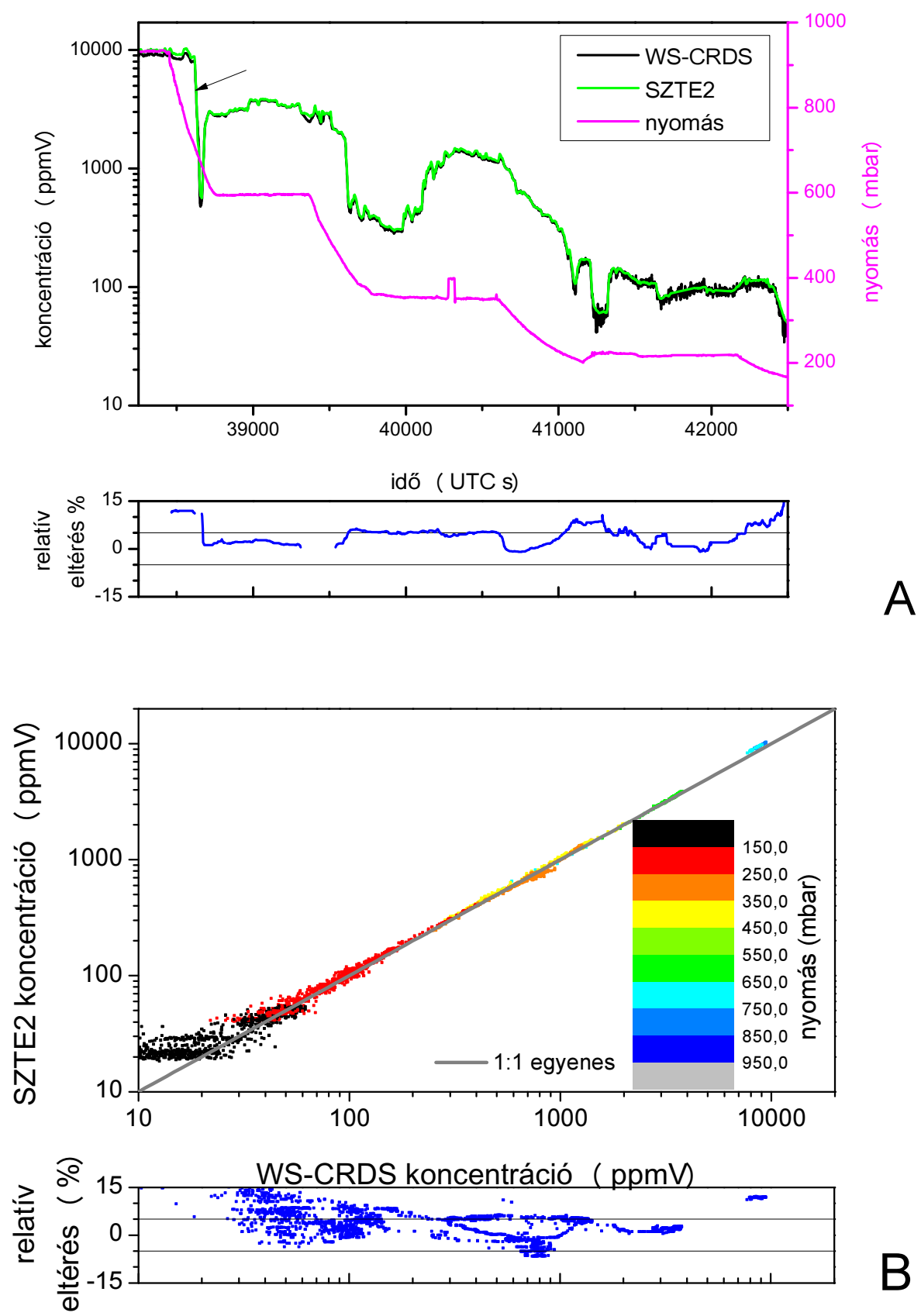

B

Ábra 29: Összehasonlítás a WS-CRDS (IAGOS GHG) müszerrel. 

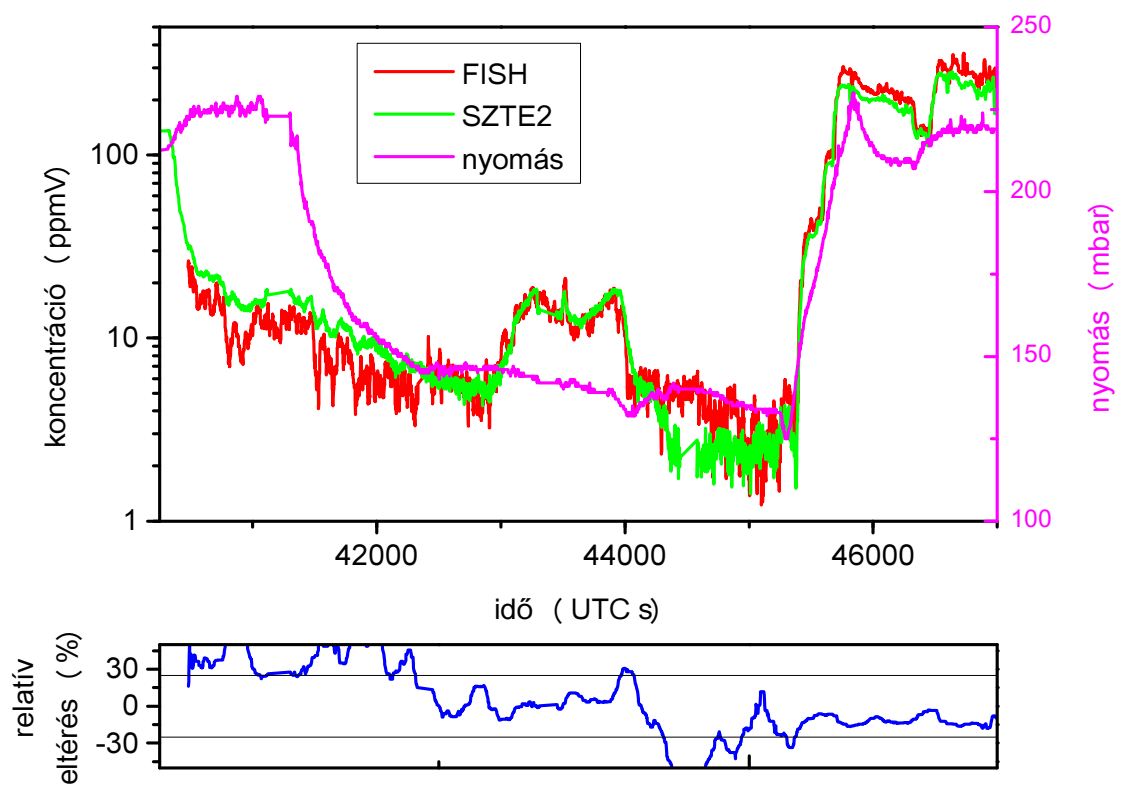

A
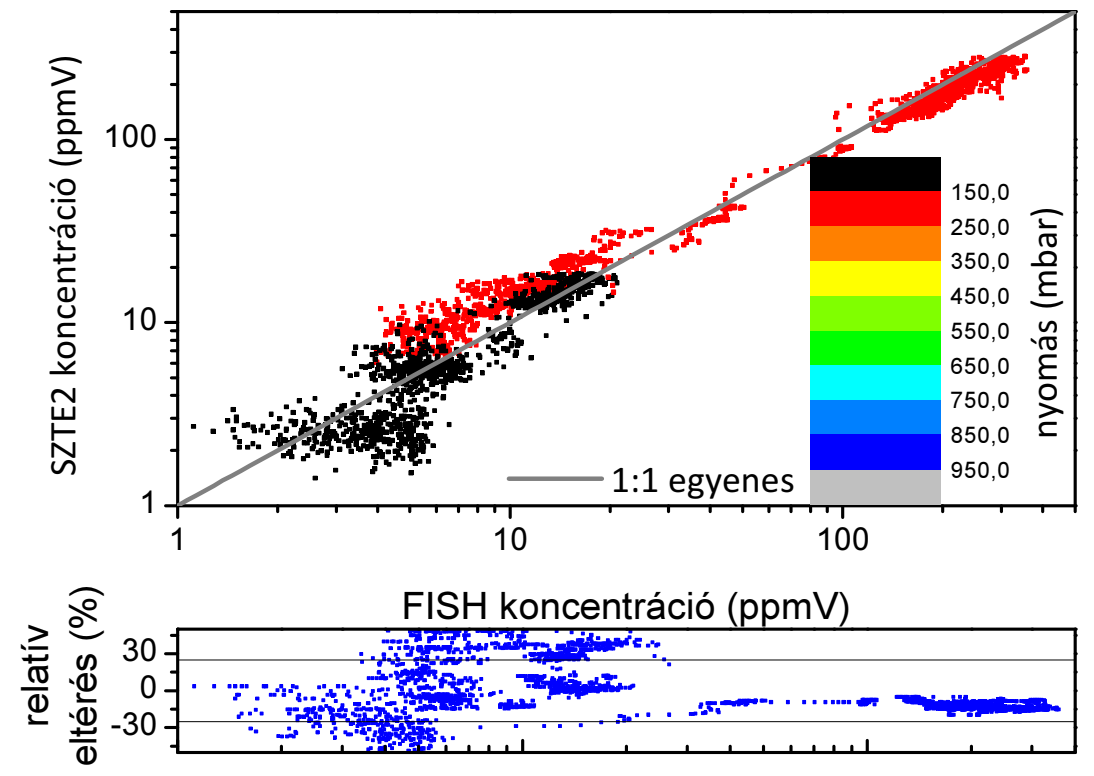

B

Ábra 30: Összehasonlítás a FISH-sel. 


\section{7 Összegzés}

Megterveztem és elkészítettem egy új kétcsatornás vízgőz-koncentráció- mérő- rendszert, melyben implementáltam az 1 . és 2 . tézispontokban bemutatott eljárásokat. A mérörendszert független összehasonlító mérések során teszteltem mind laboratóriumi, mind repülőgépes mérések során. Mindkét esetben a széles mérési tartomány miatt két műszert kellett referenciaként használnom, egyet alacsony, egyet pedig magas koncentrációk esetén. Az új mérőrendszer az összes mérés során megbízhatóan, a referencia-műszerekhez képest tipikusan 5\%-on belüli eltéréssel múködött a teljes vizsgált nyomás és koncentráció tartományon. A mérőrendszer fejlesztése során hasonló pontosságot korábban nem sikerült elérni. [117] 


\section{9 Új adatgyưjtő és mérésvezérlő rendszer fejlesztése}

\subsection{Célkitǔzés}

A VT elektronika alapvetően alkalmas PA mérések elvégzésére, azonban részben korlátozott programmemóriája, részben elavultsága miatt korlátozó tényezővé vált újabb fejlesztésekhez, újabb mérési technikák, újabb ötletek kipróbálásához. A felhasználása során hátráltató körülményként jelentkezett, hogy speciális programnyelvének köszönhetően nehézkesen lehet vele méréseket automatizálni. Néhány alkalmazásnál, mint a repülőgépre telepíthető műszereknél jelentős hátrányt jelent, hogy az elektronika mind méretben, mind pedig tömegben nagyobb, mint amit egy modern mérőrendszertől elvárható lenne.

A fenti okok miatt szükségessé vált egy új adatgyűjtő és mérésvezérlő rendszer kifejlesztése. A fejlesztések során az új rendszerrel kapcsolatos legfontosabb elvárások a következőek voltak:

- legyen alkalmas PA mérések elvégzésére,

- legalább olyan pontosan, mint az előző elektronikával lehetett,

- legalább olyan válaszidővel, mint az előző elektronikával lehetett,

- legyen autonóm működésre alkalmas,

- elterjedt programozási nyelven lehessen fejleszteni,

- legyen skálázható,

- a korábban kifejlesztett mérési rutinokat lehessen implementálni,

- új mérési rutinokat lehessen implementálni:

- $\quad 2 f$ detektálás,

- két vagy több lézer egymástól különböző modulációs frekvencián történő szimultán használata egy vagy több kamrában,

- rendelkezzen a szükséges minősítésekkel,

- méretben és tömegben legyen kisebb.

\subsection{A kiválasztott platform}

A fenti követelményeket lehet teljesíteni akár egy teljesen új fejlesztéssel is, azonban célszerúbb választásnak túnik egy ipari szabvány szerinti általános célú vezérlőre alapozni az új mérőrendszert - jelentős mennyiségű elektronikai és szoftveres fejlesztést megspórolva, 
hiszen ezen fejlesztések hibáinak feltárását, korrigálását a vezérlő gyártója végzi el. Ennek a megközelítésnek viszont hátránya, hogy a vezérlő gyártójának portfólió-változása esetén újabb fejlesztések válnak szükségessé. A lehetséges fejlesztői platformok PC104 [123], OPTO22 PAC [124]... között a kiemelkedő modularitás, a meglévő hardveres támogatás és a LabVIEW-beli fejleszthetőség miatt a National Instruments RIO platformját választottam [125, 126].

A választott platform két részre osztható: SBRIO beágyazott rendszerek, valamint CRIO rendszerek. A két platform tagjainak alapvető felépítése megegyezik: tartalmaznak egy FPGA chipet, valamint egy determinisztikus feladatok futtatására alkalmas általános célú processzort. Az SBRIO platform tagjai számos integrált analóg/digitális be/kimenettel vannak ellátva valamint néhány típushoz $\mathrm{NI}$ C-sorozatú modulok (maximum három darab) kapcsolhatóak, melyek segítségével az eszköz funkcionalitás bővíthető (Ábra 31). A CRIO sorozat tagjai nem tartalmaznak integrált be/kimeneteket, csak NI C-sorozatú modulokkal (maximum 4-16 darab/vezérlő) lehet velük adatgyűjtést vagy jelgenerálást megvalósítani. Az SBRIO platform tagjaiban elhelyezett FPGA chipek és processzorok kisebb kapacitásúak, lassabbak. Ezekre alapozva egy maximum négy lézerből és négy PA kamrából álló mérőrendszert lehet elkészíteni. A CRIO sorozat nagy előnye, hogy több vezérlőből álló rendszereket is létre lehet hozni belőlük, így tetszőleges összetételü, bonyolultságú PA mérőrendszert lehet belölük kialakítani.

A két platform szoftveresen átjárható, azaz az egyikre megírt program a másikra könnyedén portolható, mindössze a kapacitásbeli különbségekre kell figyelmet fordítani.

\subsection{A platform kiválasztott elemei}

A repülőgépes vízgőz-koncentráció- mérő esetében egy lézerből és két kamrából álló rendszert kell vezérelnie az elektronikának, így a kisebb méretű és tömegú SBRIO platformot választottam: egy SBRIO 9642XT vezérlőt [127] (Táblázat 7) egy NI 9234 adatgyújtővel [128, 129] és egy NI 9269 jelgenerátorral [130, 131] kiegészítve. E két utóbbi egy-egy C-sorozatú modul. 
FPGA

CPU

RAM

tárhely

operációs rendszer

3.3 V digitális IO csatornák

24 V digitális IO csatornák

$\pm 10 \mathrm{~V}, 16$ bites analóg bemenet

$\pm 10 \mathrm{~V}, 16$ bites analóg kimenet

ethernet port

RS232 port

C-sorozatú bővítőhely
Spartan-3, 2 millió kapu

PowerPC $400 \mathrm{Mhz}$

$128 \mathrm{MB}$

$256 \mathrm{MB}$

VxWorks

110

$32+32$

32

4

1

1

3

Táblázat 7: A választott SBRIO 9642XT beágyazott vezérlö fontosabb paraméterei. 


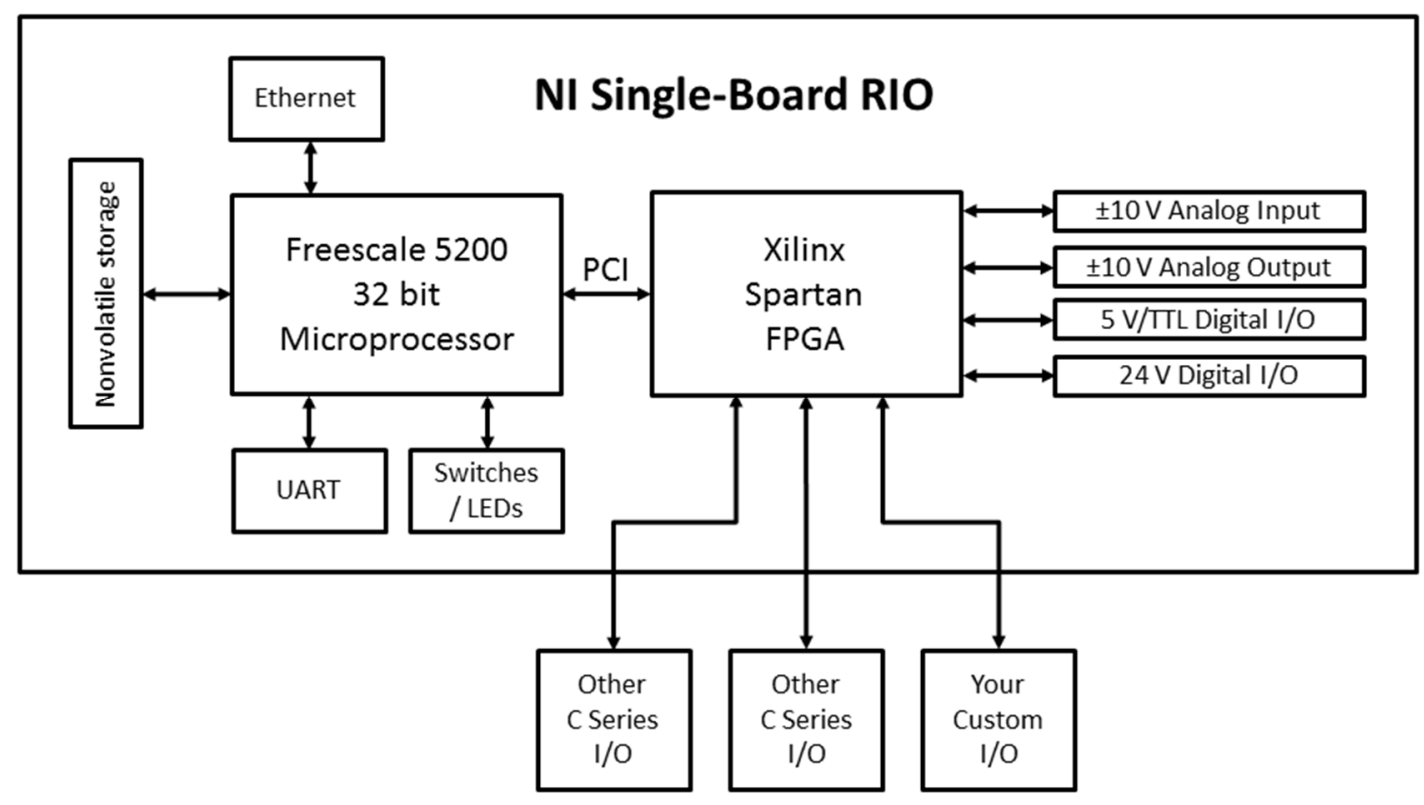

Ábra 31: A választott SBRIO 9642 beágyazott vezérlö felépitése [132] ${ }^{30}$. /nonvolatile storage: nemfelejtö tárhely, UART: soros port, Switches/LEDs: kapcsolók/LED-ek, analog input: analóg bemenet, analog output: analóg kimenet, digital I/O: digitális be/kimenet, other $\mathrm{C}$ series IO:

C-sorozatú bővitömodul, your custom I/O: egyedi bövítömodul/

Az NI 9234-es adatgyűjtő egy 24 bites, négycsatornás, \pm 4,5 V-os, csatornánként 110 dB izolált $51200 \mathrm{~S} / \mathrm{CH} / \mathrm{s}$-es digitalizáló modul. Az egyes csatornák programozhatóak DC, AC, AC +2 mA IEPE csatolással.

Az NI 9269-es jelgenerátor egy 16 bites négycsatornás, \pm 10 V-os, csatornánként 250 Vrms izolált 100 kS/Ch/s digitál-analóg konverter.

A két bővítő modul a legnagyobb pontosságot igénylő feladatokhoz, mint lézer meghajtás, hőmérsékletstabilizálás, valamint mikrofonjel mérése használható, míg a vezérlőre integrált csatornák a kisebb precizitást igénylő feladatokhoz, mint nyomásmérők, PT1000 RTD ${ }^{31-k}$ jelének a mérésére, gázkezelés vezérlésére, kamra/csőfútések szabályozására használhatóak. A tervezett új rendszer felépítése a fontosabb funkciókkal az alábbi, 32. ábrán található.

\footnotetext{
${ }^{30}$ Az ábrát annak szerzői jogának tulajdonosa (National Instruments, Inc) engedélyével az eredetivel azonos tartalommal, az eredetivel lényegileg megegyező dizájnnal jobb minőségben készítettem el.

${ }^{31}$ Resistive Tempereture Detector: ellenállás-hőmérő
} 


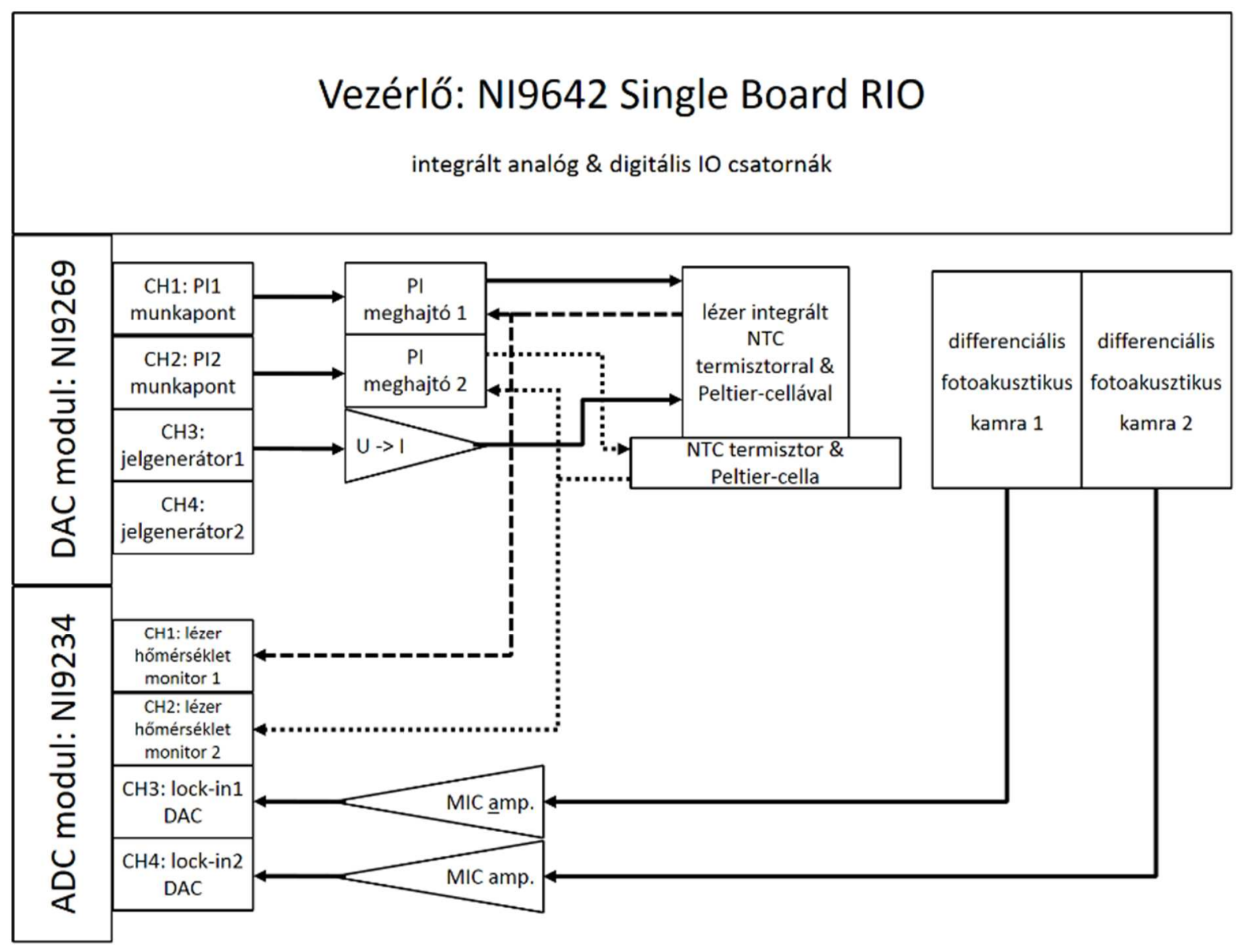

Ábra 32: Az új vezérlöelektronikára alapozott mérörendszer vázlatos felépítése.

A megfelelő platform kiválasztása után a fejlesztési feladatokat két részre lehet szétosztani:

1. teljesítmény-meghajtó illetve szenzorillesztő áramkörök tervezése, elkészítése,

2. az eszköz megfelelő múködéséhez, múködtetéséhez szükséges programok elkészítése.

\subsection{Saját fejlesztésű perifériák}

Egy, gyakorlatban is alkalmazható PA mérőrendszerhez az alapvető funkciókon kívül biztosítani kell:

- megfelelően stabil tápellátásokat,

- hőmérséklet-szenzorok (PT1000 RTD) jelkondicionálását,

- fútések PWM alapú teljesítmény-meghajtását,

- gázkezelés teljesítmény-fokozatainak meghajtását (mágnesszelepek, szolenoid szelepek...) 
Ezen funkciók múködése általában nem igényel extrém precizitást, megvalósításuk triviális, a tervezés során mindössze arra kellett figyelemmel lenni, hogy az egyes felhasznált komponensek kis hőmérsékleti tényezőjűek legyenek. Ezek megvalósítását részleteiben nem ismertetem.

\subsubsection{Mikrofonerősítő}

A mikrofonerősítő egy AC csatolt INA 128 (Texas Instruments) instrumentális erősítő IC-n alapul (Ábra 33). A két mikrofon jelét egy-egy $500 \mathrm{~Hz}$ levágási frekvenciájú felüláteresztő RC szúrőn keresztül az erősítő bemenetére kapcsoltam. Az instrumentális erősítő IC kimenetét egy OPA 177 (Texas Instruments) múveleti erősítőn és egy felüláteresztő szűrőn $(100 \mathrm{~Hz})$ keresztül csatoltam vissza az INA 128 IC referencia bemenetére. Ez a kapcsolás lényegileg megegyezik az IC adatlapjában javasolt megoldással. Az erősítést 50-szeresre választottam. Ekkor a mikrofon saját zaja nagyjából egy nagyságrenddel nagyobb, mint az új vezérlőelektronikában implementált lock-in erősítőé. A mikrofonerősítőt egy önálló nyáklemezen készítettem el, amit akár a PA kamrára is lehet rögzíteni, hogy minél közelebb legyen a mikrofonokhoz.

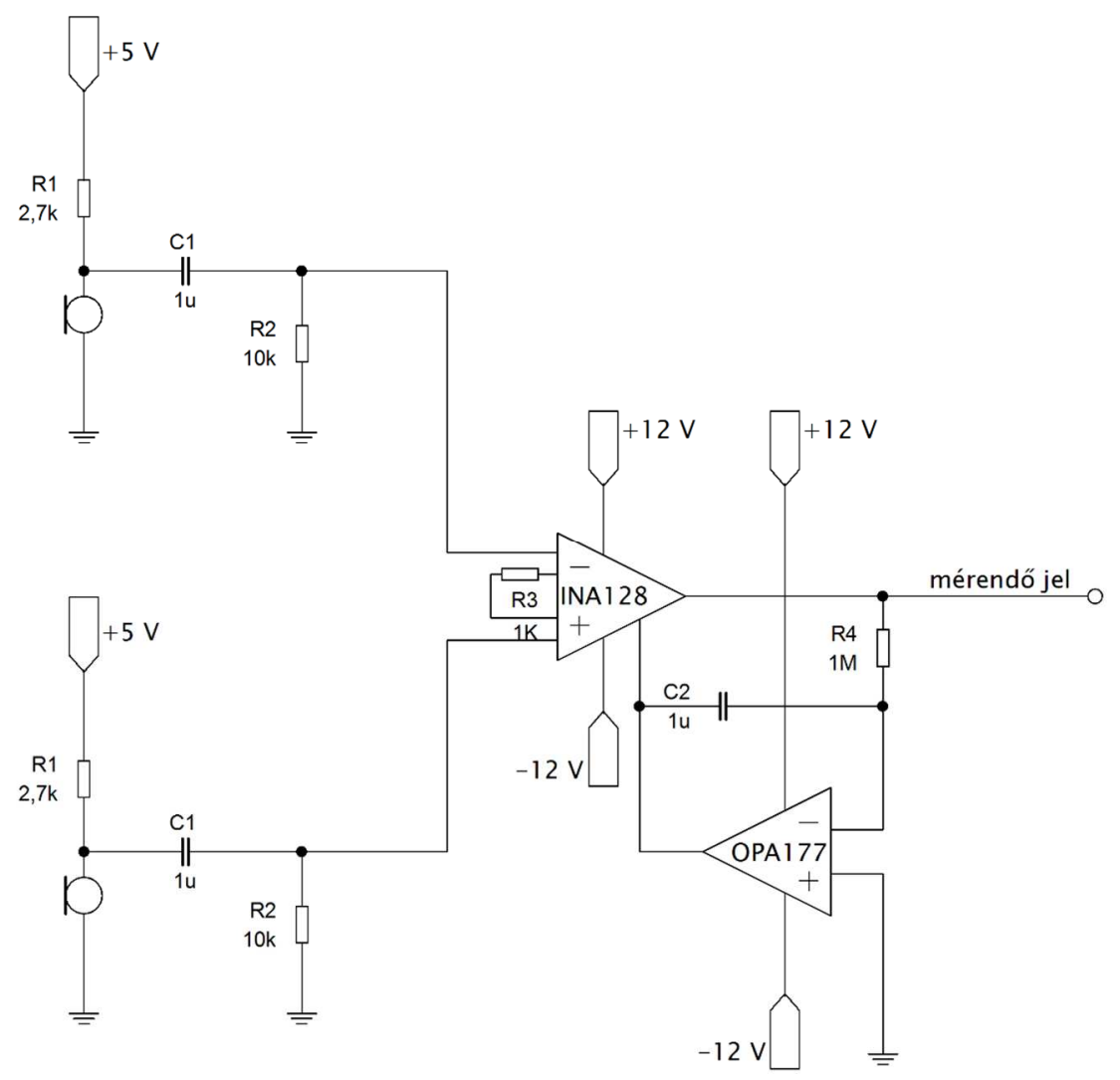

Ábra 33: A mikrofonerösítö elvi kapcsolási rajza. 


\subsubsection{Lézer hőmérséklet stabilizáló}

A lézer hőmérséklet-stabilizálását a korábban bemutatott, M. Szakáll által kifejlesztett kétszeres sémával oldottam meg. Mind a lézerchip, mind pedig a lézer tokozása hőmérsékletének stabilizálásához PI szabályozáson alapuló integrált Peltier-cella meghajtó modult választottam (Wavelength Electronics HTC1500-62). Ez egy olyan eszköz, amely egy ellenállás hőmérőre (PT100, PT1000, NTC, PTC) állandó (egy ellenállással beállítható nagyságú) áramerősséget kapcsol, és méri a hőmérőn eső feszültséget $U_{\text {Tmért. Egy másik bemenetére }}$ akkora feszültséget kell kapcsolni $\left(\cup_{\text {Tset }}\right)$, amekkorának $U_{\text {Tmért }}$-nek kell lennie beállítandó hőmérséklet esetén. A modulra kell rákötni a meghajtandó Peltier-cellát is. A proporcionális erősítést egy ellenállással (0-100 k $\Omega)$, az integrálási időt pedig egy kondenzátorral $(0-10 \mu \mathrm{F})$ lehet beállítani. A kapcsolásban az ellenállásként egy digitálisan, SPI kommunikációval vezérelhető potenciométert (MCP4162-104E/P (Microchip)) helyeztem el, hogy szükség esetén akár szoftveresen is változtatni lehessen az erősítés mértékét. Digitálisan vezérelhető kondenzátorok csak a pF tartományban érhetőek el, ezért az integrálási időt konstans 2 másodpercnek választottam. A kísérleti eredmények azt mutatták, hogy 1-5 s integrálási idővel a hőmérséklet-stabilizálás megfelelően működik.

A vezérlőmodul által kiadható maximális áramerősséget két lába közötti ellenállással lehet limitálni, rövidzárral pedig 0 A-ra levenni. A proporcionális erősítést és az integrálási időt csak akkor szabad állítani, amikor a modul nem ad ki a Peltier-cellára áramerősséget, így szükséges volt az áramlimitáló ellenállással párhuzamosan kapcsolva egy relét is elhelyezni. A relé alapállapotában zárva van, a hőmérséklet-stabilizálás csak akkor aktív, amikor a relét nyitjuk. Ezen felül a modul tápellátását egy DC szilárdtest-relével kapcsolom. Ezzel az elrendezéssel meghibásodás vagy rendellenes működés esetén ki lehet kapcsolni a hőmérséklet stabilizálást, hogy megvédjük a lézert az esetleges hőmérsékleti sokk okozta esetleges károsodástól.

Az elkészített kapcsolásban lehetőséget biztosítottam a digitális potenciométer helyett egy hagyományos potenciométer használatára, valamint az áramkorlátot nullára csökkentő relé manuális kapcsolására is. Mindkét elemnél egy-egy tolókapcsoló segítségével lehet váltani a kétféle üzemmód között. A manuális üzemmód opció azért előnyös, mert így más, SPI vezérlővel, vagy $24 \mathrm{~V}$ digitális kimenettel nem rendelkező vezérlőelektronikák esetén is lehetőség nyílik az áramkör használatára. 
Lézer PI hőmérséklet-stabilizálás

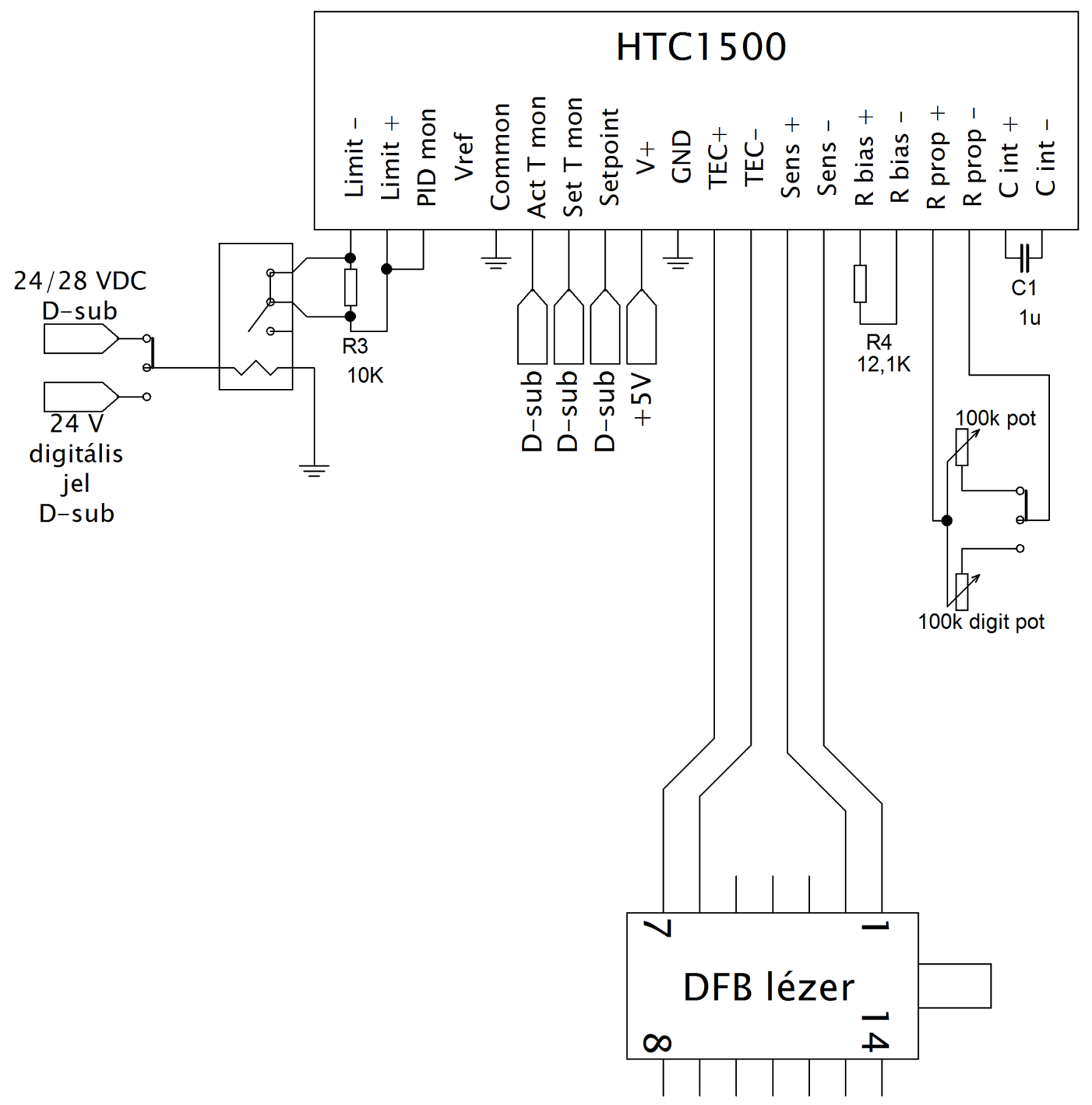

Ábra 34: A lézer-hőmérsékletstabilizáló áramkörének a kapcsolási rajza. A lézer tokozásának hömérsékletstabilizálásához is ugyanezt az elrendezést használom.

\subsubsection{Lézer árammeghajtás}

A lézer árammeghajtásához kétféle kapcsolást teszteltem, melyek lényegileg azonos tulajdonságokkal bírnak: Az első egy integrált feszültség-áramerősség konverter melyet speciálisan diódalézer meghajtáshoz terveztek, a másik pedig egy egyszerű lineáris feszültségvezérelt áramgenerátor. 


\subsubsection{Integrált vezérlő}

Az integrált vezérlő egy ATLS250MA103 típusú (Analog Technologies) feszültségvezérelt lézermeghajtó áramkör [133]. A meghajtó [0; 2.5] V vezérlőjelet konvertál [0; 250] mA áramerősséggé. A kimenő áramerősséget egy ellenállás segítségével lehet korlátozni. A tesztek során az adatlapjában javasolt kapcsolási rajz alapján készítettem el az áramkört. A használt lézer legfeljebb 120 mA áramerősséggel hajtható meg, ezért az áramerősség-limitet $118 \pm 1 \mathrm{~mA}$-re állítottam be.

\subsubsection{Saját tervezésü meghajtó-áramkör}

A 35. ábrán látható kapcsolást a Texas Instruments által javasolt áramkör [134] alapján méreteztem és készítettem el. A kapcsolás [0;-10] V vezérlőjelet lineárisan alakít át [0;120] mA áramerősséggé. $A z$ áramerősség beállításáért a műveleti erősítő felel, míg a tranzisztor teljesítmény-meghajtóként van jelen. A kapcsolásban a lézeren átfolyó maximális áramerősséget az R2 jelű ellenállással lehet beállítani az alábbi számérték-egyenlet alapján:

$$
I_{\text {lézer_limit }}(m A)=\frac{R 2(\Omega)}{10}
$$

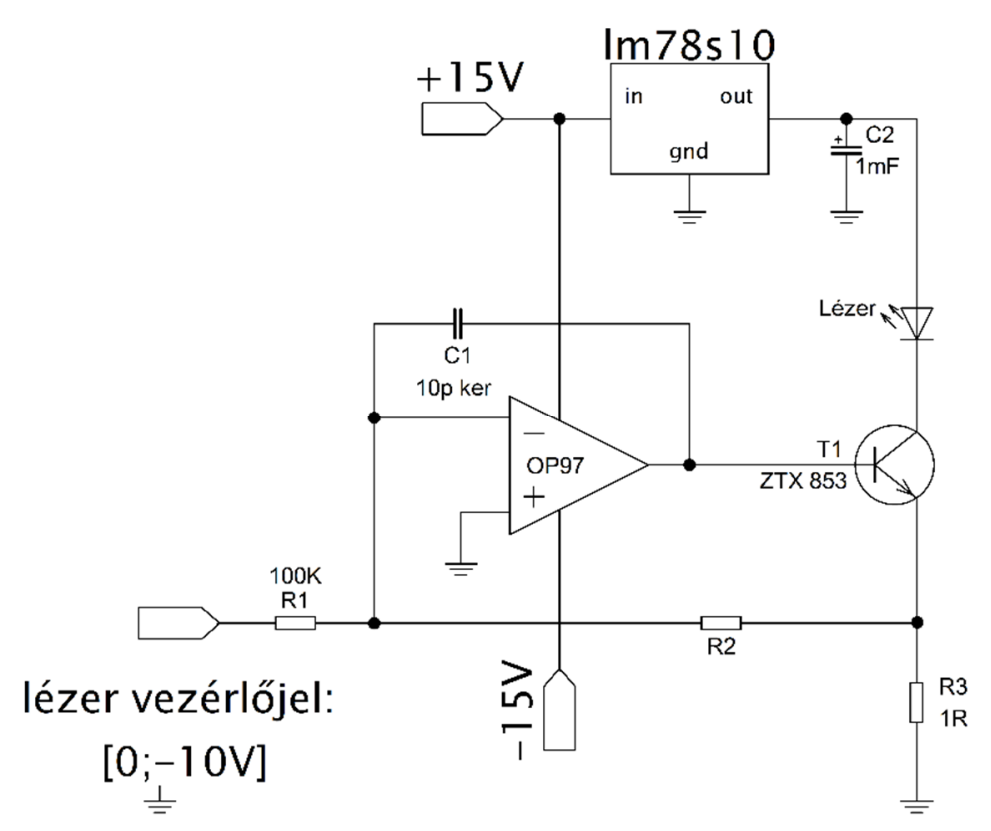

Ábra 35: A saját tervezésü lézermeghajtó áramkör kapcsolási rajza. 


\subsubsection{A kapcsolások összehasonlítása}

Mind a két bemutatott lézermeghajtó áramkör alkalmas PA rendszerben való alkalmazásra, sávszélességük, precizitásuk és pontosságuk megfelelő. Az integrált vezérlő családjában azonos tokozással és lábkiosztással elérhetőek modellek 6 A maximális kimenő áramerősséggel is, míg a saját készítésű lézer meghajtóval 2 A maximális áramerősség érhető el. Szükség esetén a tápellátás és a tranzisztor lecserélésével ez a határ növelhető. A felhasználás szempontjából a legnagyobb különbséget az adja, hogy az integrált megoldásnál 1,2 V míg a saját készítésű meghajtónál $-10 \mathrm{~V}$ feszültséghez tartozik $120 \mathrm{~mA}$ áramerősség. $\mathrm{A}$ lézer meghajtójának a vezérléséhez használt NI9269 DAC modul a [-10; +10] V tartományt 16 bit felbontással képes kiadni, tehát a saját készítésű megoldással 8,33-szor nagyobb felbontással lehet vezérelni a lézerre adott áramerősséget. A két meghajtó számszerűsített összehasonlítása a 8. táblázatban található meg.

\begin{tabular}{ccc}
\hline \hline meghajtó & integrált vezérlő & $\begin{array}{c}\text { saját készítésű } \\
\text { vezérlő }\end{array}$ \\
\hline effektív bitmélység & 11,8 & 15 \\
vezérlő feszültség felbontás $(\mu \mathrm{V})$ & 305,18 & 305,18 \\
áramerősség felbontás $(\mu \mathrm{A})$ & 30,5 & 3,66 \\
hullámhossz felbontás $(5 \mathrm{pm} / \mathrm{mA}$ & 152,5 & 18,3 \\
esetén) (fm) & & \\
\hline \hline
\end{tabular}

Táblázat 8: A lézermeghajtó kapcsolások összehasonitása.

A nagyobb áramerősség felbontást kiegészítő áramkör segítségével el lehetne érni az integrált vezérlő esetén is, azonban akkor a vezérlő egyszerűségét fel kellene adni. Éppen ezért a rendszer felépítésének véglegesítése során a saját készítésű vezérlő használata mellett döntöttem.

\subsubsection{Tervezési szabályok}

Az egyes funkciók elkészítése során a legfontosabb szempont a zajok, az egyes modulok, csatornák közötti áthallás minimalizálása volt. A két PI szabályozót, a lézer árammeghajtóját valamint a lézert egy NYÁK lemezre terveztem, hogy ezek egy közös tokozásba kerülve egy integrált modult alkossanak. Az egyes funkciók izolálását dedikált földelés szigetekkel, 
valamint legalább 5 mm-es fizikai távolság tartásával valósítottam meg. Ez utóbbi alól csak a lézer bekötésénél a kisebb lábtávolság miatt tettem kivételt. Minden funkció dedikált tápellátást is kapott, melyek stabilizálását LM78XX, LM78SXX, PT78ST1XX feszültségstabilizátorokkal valamint tantál illetve elektrolit kondenzátorokkal valósítottam meg.

A tervezésnél fontos szempont volt, hogy az elkészített rendszer komponenseit egyéb alkalmazásokban is használni lehessen. Ezen alkalmazásoknál előfordulhat, hogy nagyobb áramerősséget igénylő lézert kell meghajtani, vagy szélsőségesebb hőmérsékleti viszonyok miatt nagyobb áramerősséggel kell meghajtani az egyes Peltier-cellákat. Ezért az áramköröket úgy terveztem meg, hogy a nagy teljesítmény átvitelére szolgáló vezetékeken akár $5 \mathrm{~A}$ áramerősség is folyhasson. A PI vezérlő modulból léteznek nagyobb áramerősségre tervezettek azonos tokozással és lábkiosztással, míg a lézer meghajtójánál a fentebb említett R2 ellenállást és szükség esetén a teljesítményfokozatot kell csak lecserélni a kapcsolásban. Ennek következtében áramkör teljes újratervezése és a nyák újbóli legyártatása nélkül megvalósítható nagyobb áramerősséget igénylő lézerek és Peltier-cellák alkalmazása is.

\subsection{Az új elektronika szoftvere}

A vezérlőelektronikához elkészítettem egy szoftvercsomagot, amely három rétegből áll (Ábra 36):

- FPGA program

- $\quad$ RealTime (RT) program

- Host program

Az FPGA program felelős az időzítés-kritikus feladatokért, valamint ez vezérli az összes analóg és digitális ki és bemenetet is. A múködése során az RT programmal kommunikál, attól kapja a rendszer müködtetéséhez szükséges paramétereket, valamint annak továbbítja az összes mért és részben feldolgozott adatot.

Az RT program felelős a mérési ciklusok szervezéséért, a mért adatok feldolgozásáért mentéséért. Opcionálisan grafikus felhasználói felületet is lehet vele generáltatni, melyhez egy PC-ről ethernet kapcsolattal lehet hozzáférni. Múködése során az FPGA programmal kommunikál a fent említett módon. A mért adatokat opcionálisan soros porti kommunikációval továbbítja egy központi adatgyűjtőbe. 
Laboratóriumi üzemeltetéshez használható a Host program, amely a fejlesztéshez használt PC-n futtatható, elsősorban grafikus felhasználói felületként, funkcionál, de ennek segítségével is megvalósítható a mért adatok mentése. Rendszerintegrációs feladatok ellátására is ez a program használható. A Host program semmilyen hatással sincs a rendszer múködésére valamint a mérőrendszer rendeltetésszerű használata során - repülőgépre telepítve - a futtatásához szükséges PC hely, súly és elektromos fogyasztás igénye miatt kerülendő, így ennek felépítését a továbbiakban nem részletezem.

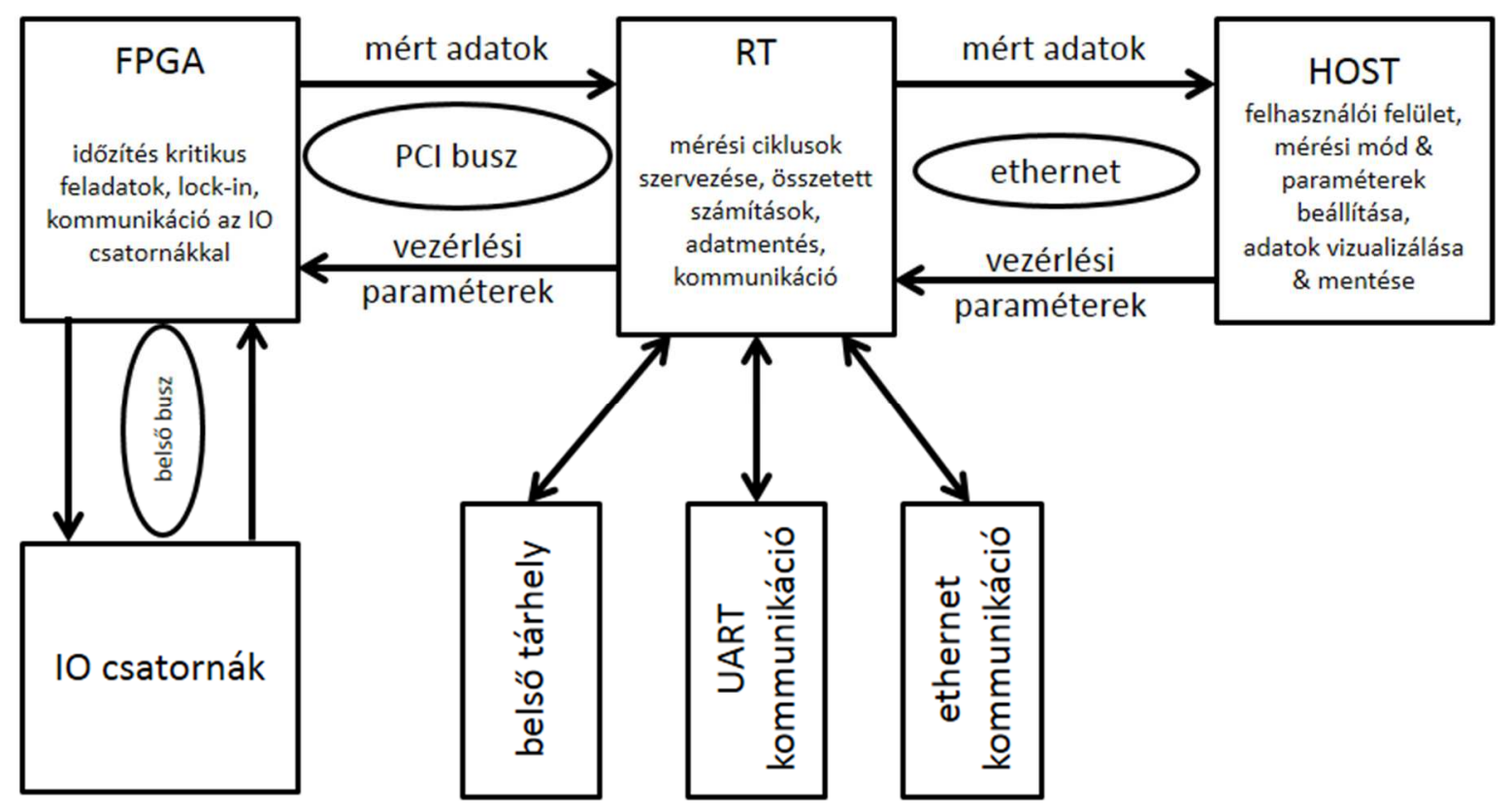

Ábra 36: A különböző programrétegek, azok funkciói és az egymással való kommunikáció.

\subsubsection{Az FPGA program}

\subsubsection{Lézermeghajtás és lock-in}

Az FPGA program legfőbb feladata a lézermeghajtó vezérléséhez használt jel előállítása, a mikrofon jelének digitalizálása, majd pedig Lock-in technikával való feldolgozása (Ábra 37). Ehhez egy PLL $^{32}$ alapú jelgenerátort készítettem, ami egyrészt 100 kHz mintavételezési frekvenciával előállítja a lézermeghajtóra kapcsolt vezérlőjelet, amelyben a moduláció lehet akár szinusz, akár négyszög alakú is. A moduláció frekvenciáját, a jel DC és AC szintjét tetszőlegesen lehet változtatni. A lézermeghajtó áramkör kialakítása révén a lézerre nem lehet véletlenül meghibásodást eredményező túl nagy áramerősséget kapcsolni. Fordított

\footnotetext{
${ }^{32}$ phase locked loop
} 
polaritású áramerősség egyrészt a tranzisztor egyenirányító tulajdonságai miatt sem fordulhat elő, másrészt viszont FPGA szinten is letiltottam a pozitív vezérlő feszültségek kiadását is.

A mikrofon jelét $51200 \mathrm{~Hz}$ frekvenciával digitalizálom, valamint ugyanezzel a frekvenciával előállítom a lock-in jelfeldolgozáshoz szükséges szinusz és koszinusz referenciajeleket is szintén PLL jelgenerálást alkalmazva. Az integrálási idő 1/51200 s lépésközzel állítható legfeljebb 1000 s értékig. A lézer meghajtásához használ jelgenerátor és a lock-in referenciajelgenerátora egy közös, 40 Mhz frekvenciájú órajelből van származtatva, így biztosított a frekvenciák azonossága.

A lock-in referenciájaként generált szinusz és koszinusz értékekből a megfelelő trigonometrikus azonosságok segítségével előállítom ezeket kétszeres frekvencián is, és ezeket referenciaként alkalmazva is ellehet végezni mikrofon jelének $2 \mathrm{f}$ lock-in kiértékelését is. Ezt a mérési opciót csak implementáltam az FPGA chipben, valamint teszteltem az alapvető múködését. Bízok benne, hogy a későbbi felhasználások, alkalmazások fejlesztése során hasznos lesz ez az opció. Hasonló módon akár többszörös frekvencián történő detektálást is meg lehet valósítani.

A fent bemutatott jelgenerálást és jelfeldolgozást kétszeresen hoztam létre: két jelgenerátort (f1, f2) és nyolc lock-in erősítőt $\left(\mathrm{CH}_{1} \mathrm{f}_{1}, \mathrm{CH}_{1} 2 \mathrm{f}_{1}, \mathrm{CH}_{1} \mathrm{f}_{2}, \mathrm{CH}_{1} 2 \mathrm{f}_{2}, \mathrm{CH}_{2} \mathrm{f}_{1}, \mathrm{CH}_{2} 2 \mathrm{f}_{1}, \mathrm{CH}_{2} \mathrm{f}_{2}, \mathrm{CH}_{2} 2 \mathrm{f}_{2}\right)$ valósítottam meg. Ennek segítségével két mérőkamrát és két lézert (akár különböző modulációs frekvenciákon) lehet szimultán módon használni és bármelyik kamrához hozzá lehet rendelni bármelyik lézert akár 1f, akár $2 \mathrm{f}$ jelfeldolgozással. A program tervezésekor a megfelelő múködés biztosítása mellett a skálázhatóság volt a legfontosabb szempont. A múködést definiáló programot úgy írtam meg, hogy szükség esetén további lézereket és további mérőcsatornákat is lehessen alkalmazni anélkül, hogy lényeges változtatásokat kelljen végrehajtani a programkódban: Mindösszesen három tömb méretét kell megváltoztatni, valamint definiálni kell, hogy melyik hardver ki és bemenetet akarjuk használni. A választott SBRIO9264 kontroller esetén maximum négy lézert és négy mérőkamrát lehet alkalmazni, míg CRIO platformon az alkalmazott lézerek és mérőkamrák számát lényegileg korlát nélkül lehet növelni. 


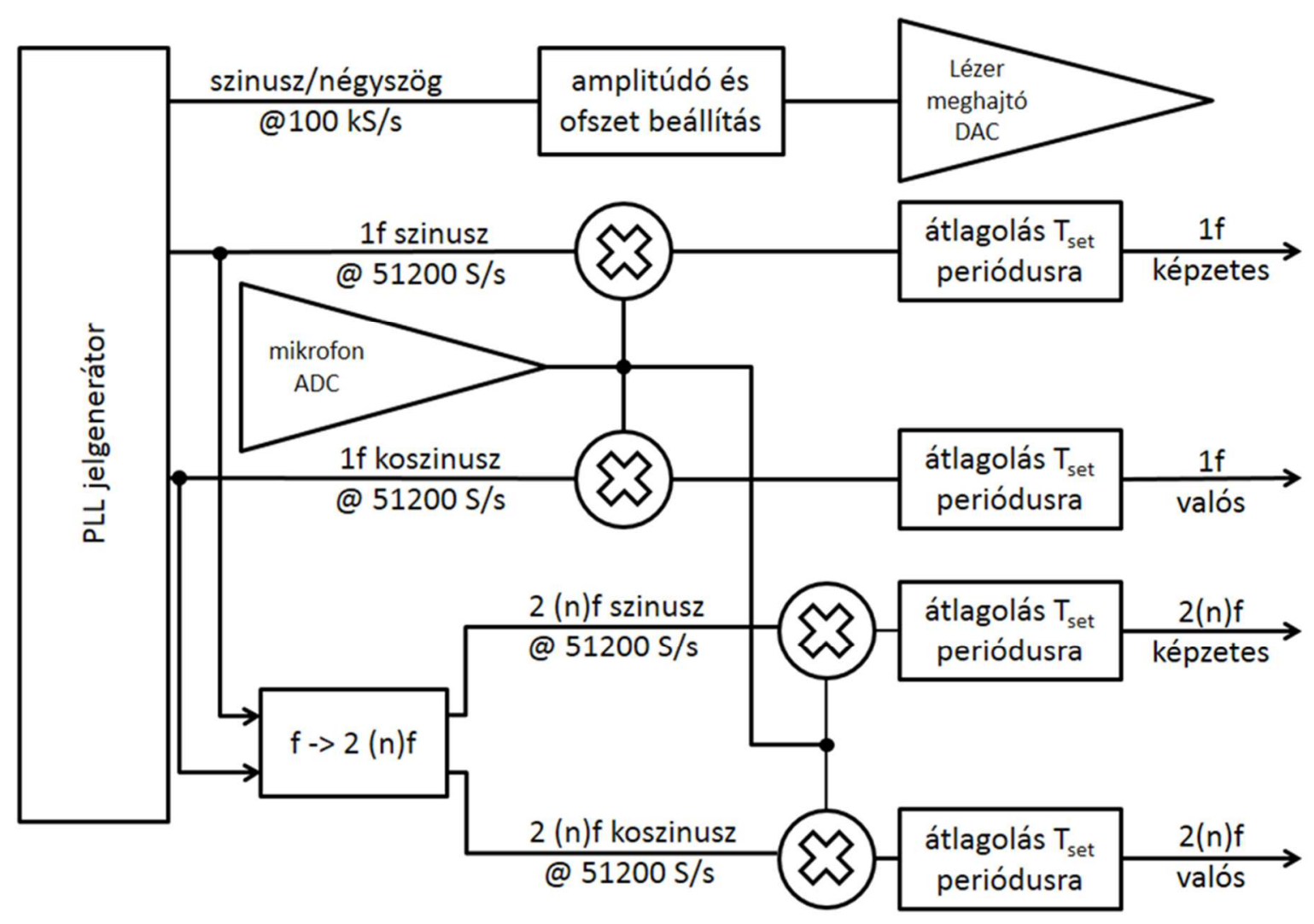

Ábra 37: Az Implementált 1f-2-f lock-in FPGA programjának sematikus vázlata.

\subsubsection{Egyéb funkciók}

Az FPGA-ban implementált többi funkció igen egyszerű, azokat külön részletezés nélkül csak felsorolom:

- referenciafeszültség szolgáltatása lézer hőmérsékletstabilizálásához,

- integrált analóg kimenetek vezérlése, az RT programban megadott értékekkel; pl.: áramlásszabályozók, proporcionális szelepek... meghajtásához,

- integrált analóg feszültségbemenetek jelének beolvasása; pl.: nyomásmérők, hőmérők...,

- PWM jelgenerátorok 3,3 és $24 \mathrm{~V}$ feszültségeken; pl.: fútések teljesítményének beállításához,

- SPI portok; pl.: lézer hőmérsékletszabályozója proporcionális erősítésének beállításához,

- digitális jelek vezérlése, beolvasása 3,3 és 24 V feszültségeken; pl.: relék, mágnesszelepek nyitása-zárása. 


\subsubsection{Az RT program}

Az RT program alapvetően a mérési ciklusok szervezéséért, valamint a mért adatok feldolgozásáért, mentéséért felel. Számos mérési protokollt implementáltam, melyek közül az általánosan használható fontosabbak: spektrum, rezonanciagörbe felvétele, modulációs mélység optimalizálása, valamint teljesen manuális üzemmód. Minden esetben az átlagolási idő tetszőlegesen állítható a 0,01-1000 s közötti tartományon belül, bár 0,1 s alatti átlagolási idők alkalmazása PA méréseknél, a kamra válaszideje miatt célszerútlen.

Az egyes mérési protokollokat szubrutinként valósítottam meg, hogy azokat a későbbiekben könnyedén fel lehessen használni rendszerépítés közben. A szubrutinként való kódolás lehetővé teszi az egyes protokollok állapotgép architektúrában való elhelyezését is.

\subsection{Alternatív konfigurációk}

A rendszer skálázhatóságának köszönhetően azt alternatív konfigurációkban is lehet alkalmazni, mint pl. két vagy több lézerrel ugyanabba a kamrába bevilágítva különböző modulációs és demodulációs frekvenciákat alkalmazva. Így mérőkamránként szimultán módon többféle gázfázisú komponens koncentrációját, vagy akár aeroszolok abszorpciós Ångstöm exponensét $[135,136]$ is meg lehet határozni akár több gázáramban is.

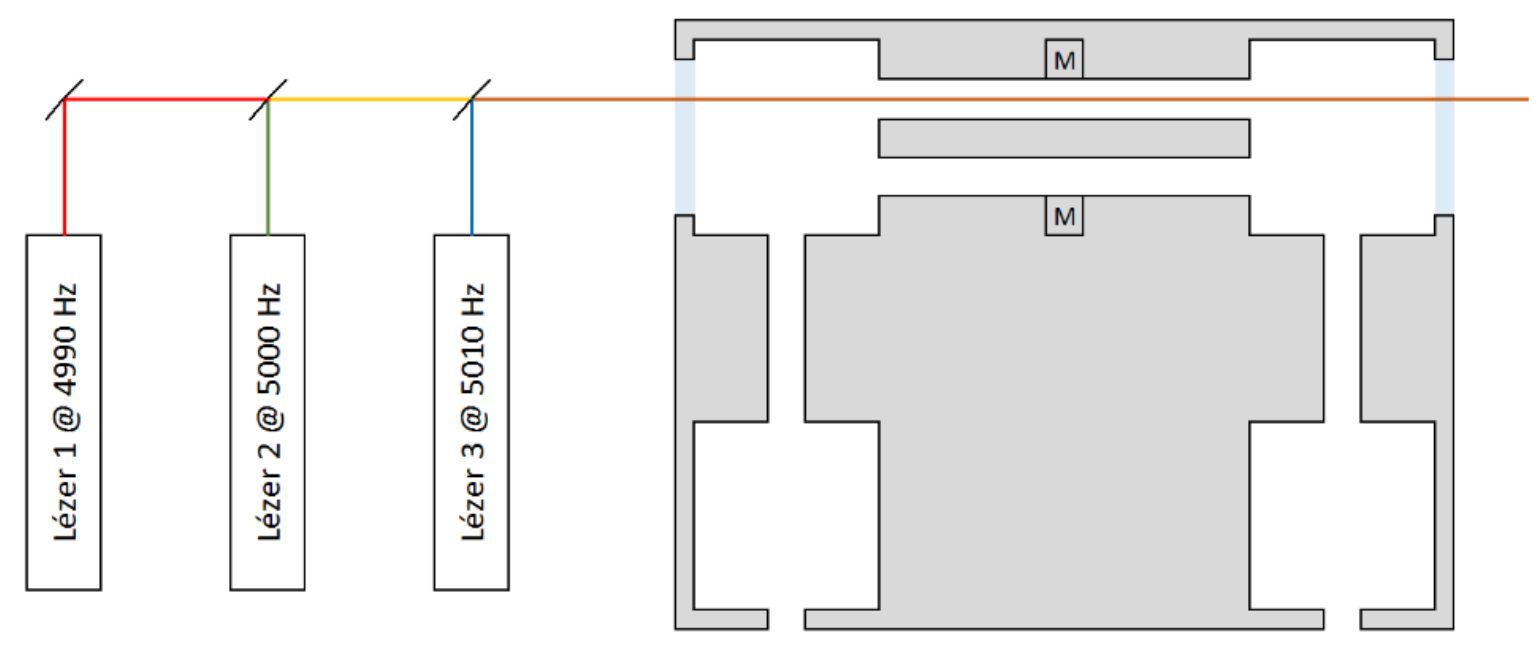

Ábra 38: Egy lehetséges alternatív mérési elrendezés: három különböző hullámhosszúságú, különböző frekvenciákon modulált lézerrel világítjuk át a PA kamra egy rezonátorát. 


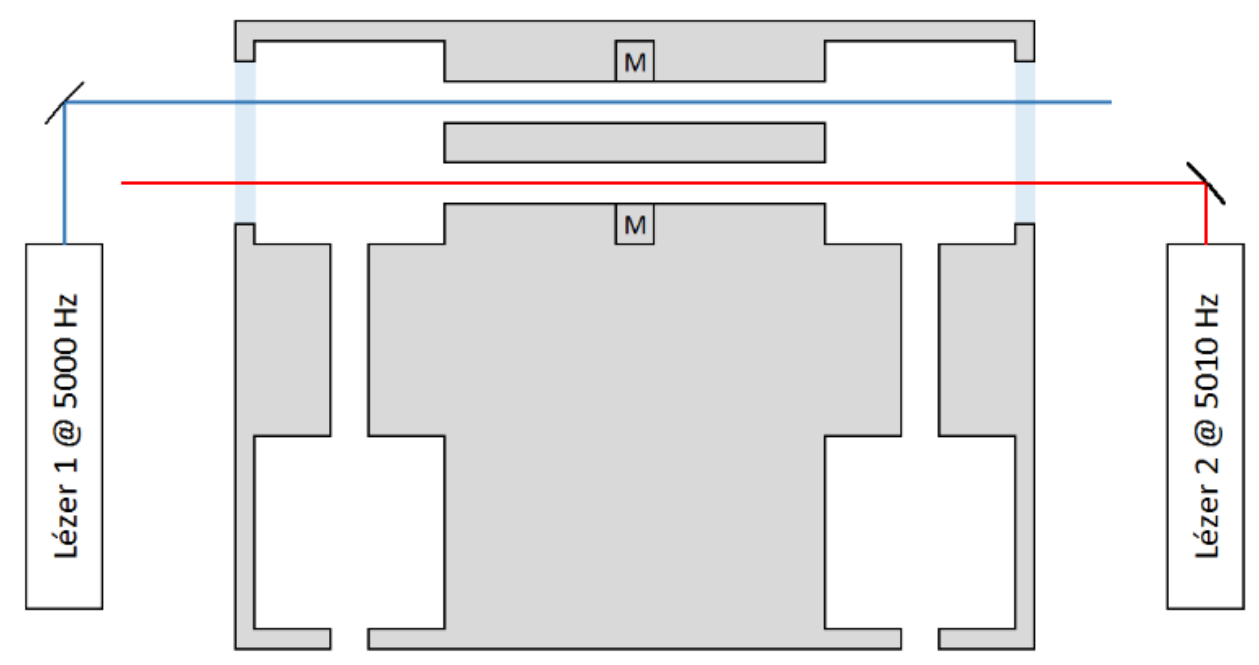

Ábra 39: Két különböző frekvencián modulált lézerrel világítjuk át a PA kamra két rezonátorát.

\subsection{Az új vezérlőelektronika tesztelése}

Az új mérőelektronikára alapozott mérőrendszer elkészítése előtt először azt teszteltem. Első lépésként a különböző analóg és digitális kimenetek müködését teszteltem oszcilloszkóp illetve multiméter segítségével. Az egyes funkciók megfelelően múködtek, a jelalakok, frekvenciák, jelszintek a beállítottnak megfelelőek voltak.

\subsubsection{Lock-in tesztelése}

\subsubsection{Dinamikus tartomány}

A lock-in tesztelésekor a jelgenerátor kimenetet közvetlenül kötöttem az ADC modul bemenetére és $1 \mathrm{~s}$ integrálási idő mellett mértem a jel- és zajszintet lépcsőzetesen változtatva a moduláció amplitúdóját, majd pedig a mérést megismételtem egy 10000-szeres feszültségosztó beiktatása mellett is, hogy a lock-in alsó detektálási küszöbét is meg tudjam határozni.

\subsubsection{Stabilitás}

A rendszer stabilitásának meghatározásához a jelgenerátort közvetlenül kötöttem az ADC modulra, stacionárius gerjesztés valamint $1 \mathrm{~s}$ integrálási idő mellett rögzítettem a mért jelet 20 napon keresztül. 


\subsubsection{Lézer hőmérséklet-stabilizálásának a tesztelése}

\subsubsection{Beállítás pontossága, reprodukálhatósága}

10-40 ํㅡ hőmérséklettartományon belül lépcsőzetesen változtattam a lézer beállítási hőmérsékletét, valamint mértem a vezérlő által kiadott hőmérséklet kimenetet is, valamint közvetlenül az NTC termisztoron eső feszültséget is.

\subsubsection{Válaszidő}

Beállítottam a lézer hőmérsékletét $15{ }^{\circ} \mathrm{C}$-ra, majd $0,1-25{ }^{\circ} \mathrm{C}$ között különböző értékekkel megnöveltem a lézer hőmérsékletét, majd pedig visszaállítottam $15^{\circ} \mathrm{C}-$ ra. A beállási időt mind a hőmérséklet növelése, mind pedig csökkentése során meghatároztam. Beállási időként a zajszinten belüli stabilizálódás értéket határoztam meg.

\subsubsection{Stabilitás}

A lézer hőmérsékletét beállítottam konstans hőmérsékletre, majd a beállási idő letelte után meghatároztam a hőmérséklet zaját, valamint 48 órán keresztül $1 \mathrm{~s}$ átlagolási idő mellett a hőmérséklet instabilitását is.

\subsubsection{Fotoakusztikus spektroszkópiai funkciók tesztelése}

A PA spektroszkópiai funkciók teszteléséhez az új vezérlőelektronikára alapozva összeállítottam egy tesztrendszert, mely egy $40^{\circ} \mathrm{C}$ hőmérsékleten stabilizált PA kamrából, egy 1392-1395 nm tartományon hangolható DFB diódalézerből (NEL NLK1E5E1AA, 26 mW) és gázkezelésből állt. Ez a rendszer lényegileg megegyezik a korábban bemutatott SZTE2 mérőrendszerrel, így a két rendszer számszerü összehasonlításra is lehetőség nyílt.

\subsubsection{Spektrum mérések}

Amplitúdó- és hullámhossz-modulált spektrumokat vettem fel, az amplitúdó-moduláltat abszorpciós spektrum adatbázissal is összehasonlítottam. A mérések során a 2 f üzemmódot is teszteltem, ennek a célja csak a funkció múködésének az igazolása volt. Meghatároztam az optimális modulációs paramétereket is.

\subsubsection{Kalibráció}

A rendszer érzékenységének meghatározásához a korábban bemutatott nedvességgenerátort használva kalibrációs méréseket végeztem két elnyelési vonalon, a lézer hangolási tartományában lévő legerősebben $\left(1392,5 \mathrm{~nm}, 3,7 \times 10^{-5} \mathrm{ppm} \times \mathrm{m}^{-1}\right)$, valamint egy gyengébben $\left(1392,8 \mathrm{~nm}, 1.5 \times 10^{-6} \mathrm{ppm} \times \mathrm{m}^{-1}\right)$ is. A második esetben a lézer teljesítményét is 
lecsökkentettem $5 \mathrm{~mW}$-ra a maximális áramerősségének $25 \mathrm{~mA}$-ra való csökkentésével. A csökkentett érzékenységű mérésre az alkalmazott nedvességgenerátor kis koncentrációkon való bizonytalanságának kiküszöbölése érdekében volt szükség.

\subsubsection{Stabilitás tesztelése}

A rendszer stabilitásának meghatározásához kis áramlási sebességgel metánt vezettem a PA kamrába. A metánnak a lézer hangolási tartományán belül egy igen sok vonalból álló, lényegi karakterisztikával nem rendelkező gyenge elnyelése van, így $100 \%$ metán esetén is kis PA jelet lehet kelteni. A lézert 1393,3 nm körüli hullámhosszra állítottam be. Ezen a tartományon a vízgőznek igen kismértékű az elnyelése, így a csövek, illetve a mérőkamra faláról történő, ppmV tartományba eső vízgőz deszorpció nem befolyásolta a méréseket. $1 \mathrm{~s}$ integrálási idő mellett 1 órán keresztül rögzítettem a PA jelet.

\subsection{Mérési eredmények}

\subsubsection{A rendszer müködése}

A rendszert definiáló FPGA program fordítási ideje nagyjából két órát vesz igénybe, de ezt elegendő csak egyszer elvégezni. Az FPGA chip erőforrásainak nagyjából 60\%-át veszi igénybe a jelenlegi program. Mérések során az RT processzor átlagos terhelése 30-50\% között változik, és sohasem nagyobb 70\%-nál. Ezek a terhelésértékek azt mutatják, hogy a rendszerben még jelentős tartalék van új ötletek, mérési módok kipróbálására, tesztelésére.

\subsubsection{Lézer hőmérséklet-stabilizálása}

A lézer hőmérsékletstabilizálásához kiadott vezérlőfeszültségnek, valamint a lézerben lévő NTC hőmérőn eső feszültségnek meg kellene egyeznie, azonban lézerhőmérséklet- függő eltérés mérhető a két érték között, melynek a nagysága $0-0,2^{\circ} \mathrm{C}$ között változik. Ez az eltérés zajszinten belül reprodukálható, így a mérőrendszerre jellemző konstansként lehet kezelni. Ennek megfelelően - elsősorban kényelmi okokból - a visszamért hőmérséklet-értékeket egy harmadfokú polinomot használva korrigálom. A korrekciót használva a hőmérséklet stabilizálódása után $0,011^{\circ} \mathrm{C}$-nál kisebb az eltérés a célhőmérséklet és a mért hőmérséklet között.

A fenti kalibráció után a mért hőmérséklet zaja 2 órás mérés során $0,21 \mathrm{~m}^{\circ} \mathrm{C}$ volt, ami $21 \mathrm{fm}$ hullámhossz-bizonytalanságnak felel meg. Ebben az értékben azonban nem csak a hőmérséklet bizonytalansága van benne, hanem az alkalmazott vezérlő zaja, valamint a 
vezetékek által összeszedett zaj is. A 48 órás stabilitásvizsgálat során az átlagértékhez képest $\pm 0,8 \mathrm{~m}^{\circ} \mathrm{C}$-nál nagyobb eltérést nem mértem, ami megfelel a PI vezérlő adatlapjában szereplő $0,8 \mathrm{~m}^{\circ} \mathrm{C}$ hosszútávú driftnek.

Különböző hőmérsékletekről kiindulva a lézer hőmérséklete $15^{\circ} \mathrm{C}$ munkapontra $\pm 0,25 \mathrm{~m}^{\circ} \mathrm{C}$-on belül stabilizálódott. A hőmérséklet teljes stabilizálódásához szükséges idő 20 és 60 másodperc között változik a hőmérséklet változtatása mértékének függvényében (Ábra 40). Ez a stabilizálódási idő repülőgépes alkalmazások esetén teljesen megfelelő, azonban egyéb alkalmazásokhoz már lassú lehet. Ezért a jövőben meg kell vizsgálni a gyorsítás lehetőségeit. $1{ }^{\circ} \mathrm{C}$-nál kisebb hőmérséklet változtatás esetén 2-7 másodperc alatt a hőmérséklet $10 \mathrm{~m}^{\circ} \mathrm{C}$ pontossággal eléri a célhőmérsékletet. Ezt az érték annyiból érdekes, hogy ez utóbbi hőmérséklet bizonytalanság a VT elektronikában beállítható legkisebb megkövetelt hullámhossz-bizonytalanság.

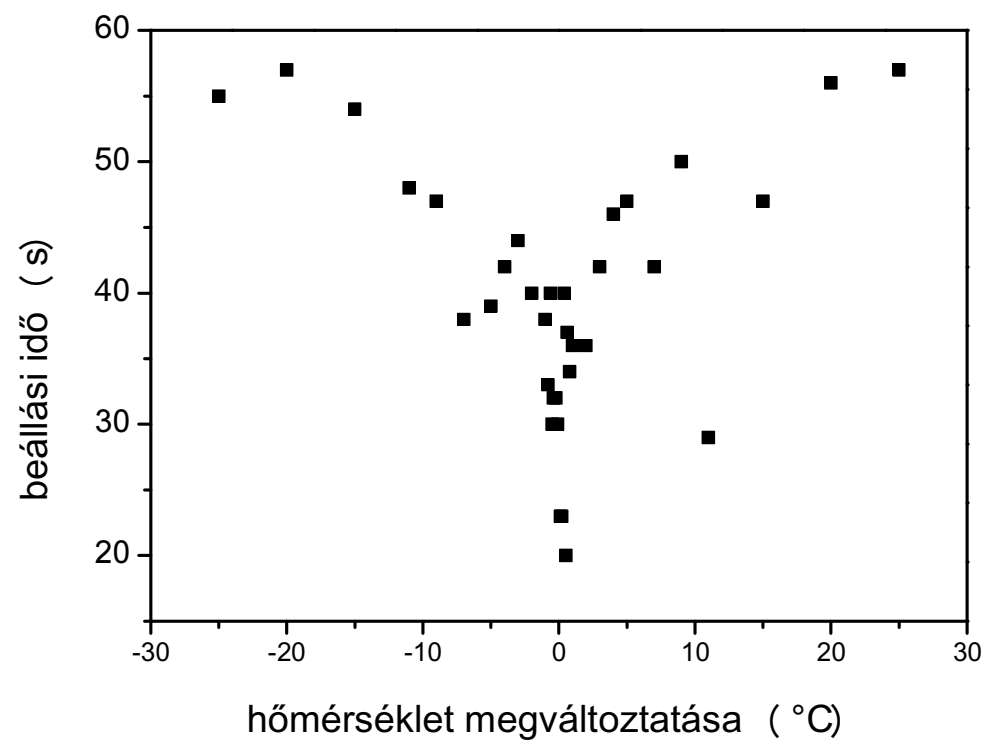

Ábra 40: A lézer hőmérsékletének zajszinten belüli stabilizálódásához szükséges idő a hőmérséklet-változtatás mértékének függvényében.

\subsubsection{Lock-in erősítő}

A Lock-in erősítő, - melyet nem csak PA mérések során lehet alkalmazni - karakterisztikája egészen $300 \mathrm{nV}$ jelszintig zajszinten belül lineáris $1 \mathrm{~s}$ integrálási idő mellett. A felső detektálási küszöböt az ADC modul $\pm 4,5$ V-os limitje jelenti. Ez 7,2 nagyságrend lineáris karakterisztikájú dinamikus tartományt jelent. A hosszú távú stabilitásteszt kiértékelése során meghatározott 
Allan deviáció értéke 4700 s, azaz optimális integrálási idő mellett 750 pV volt, ami 9,8 nagyságrendnyi dinamikus tartományt jelent. Érdekesség, hogy a 750 pV nagyjából 1/700-ad része az $A D C$ modul felbontóképességének.

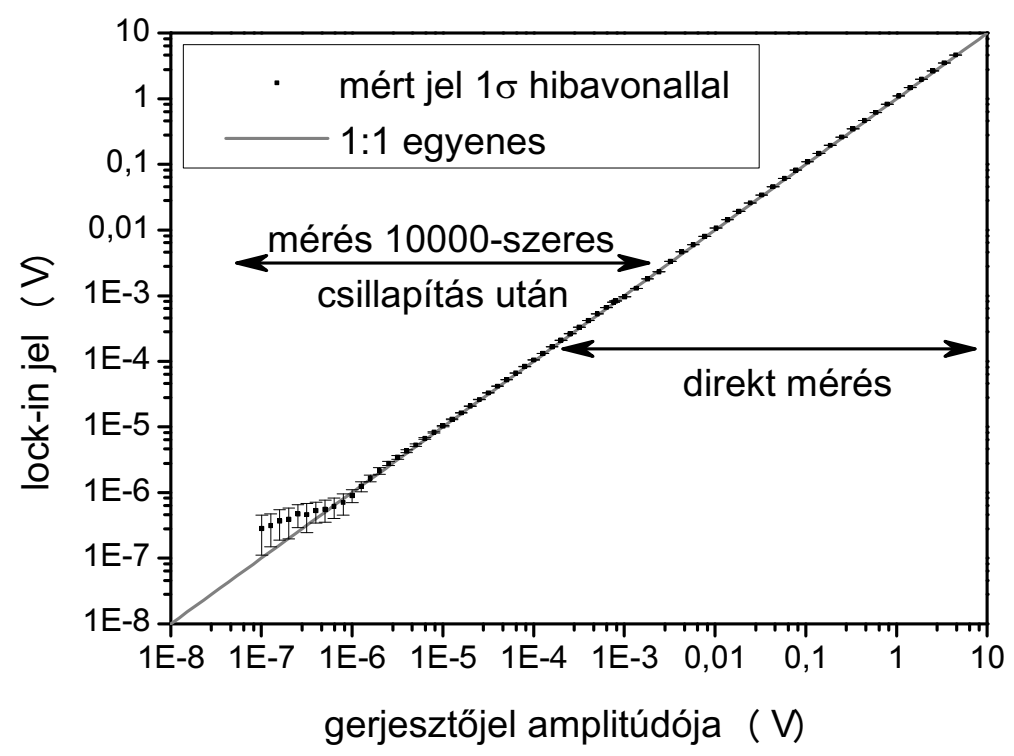

Ábra 41: Az implementált lock-in erösítő linearitása és dinamikus tartománya.

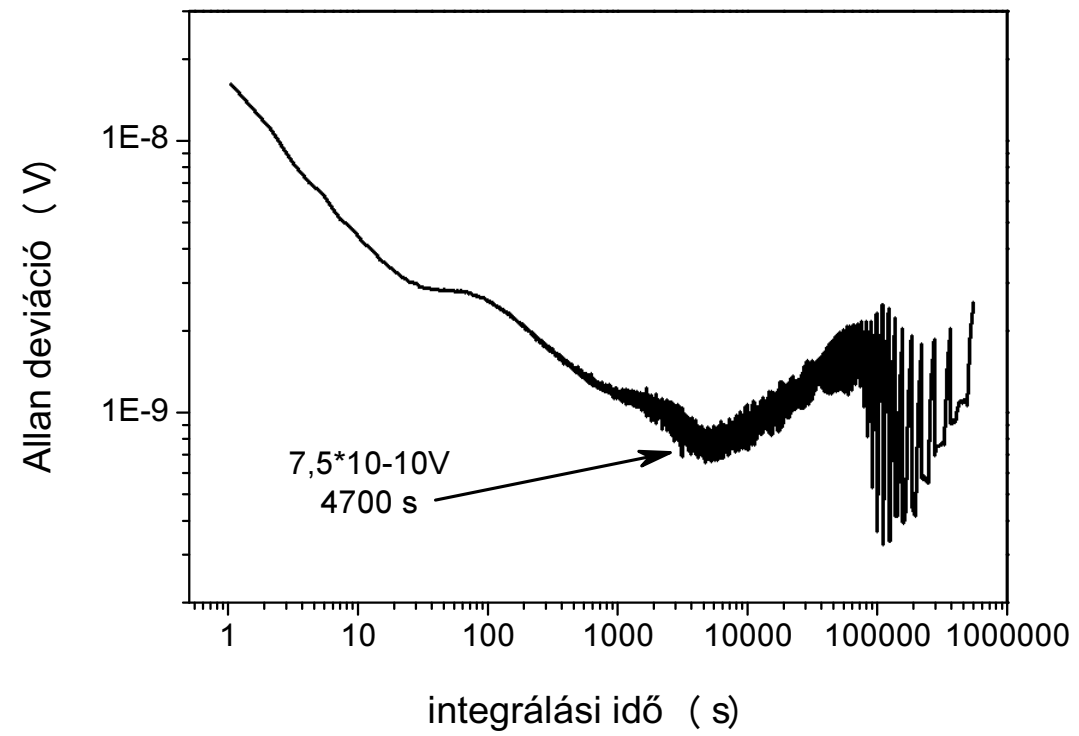

Ábra 42: Az implementált lock-in erősítő Allan deviációja az átlagolási idő függvényében. 


\subsubsection{Fotoakusztikus funkciók tesztelése}

A mérőrendszerrel felvett amplitúdó-modulált spektrum jó egyezést mutat adatbázis-béli értékekkel (Ábra 43) [100]. Hullámhossz-moduláció esetén mind 1f, mind $2 f$ detektálás esetében jellegre helyes spektrumokat kaptam (Ábra 44).

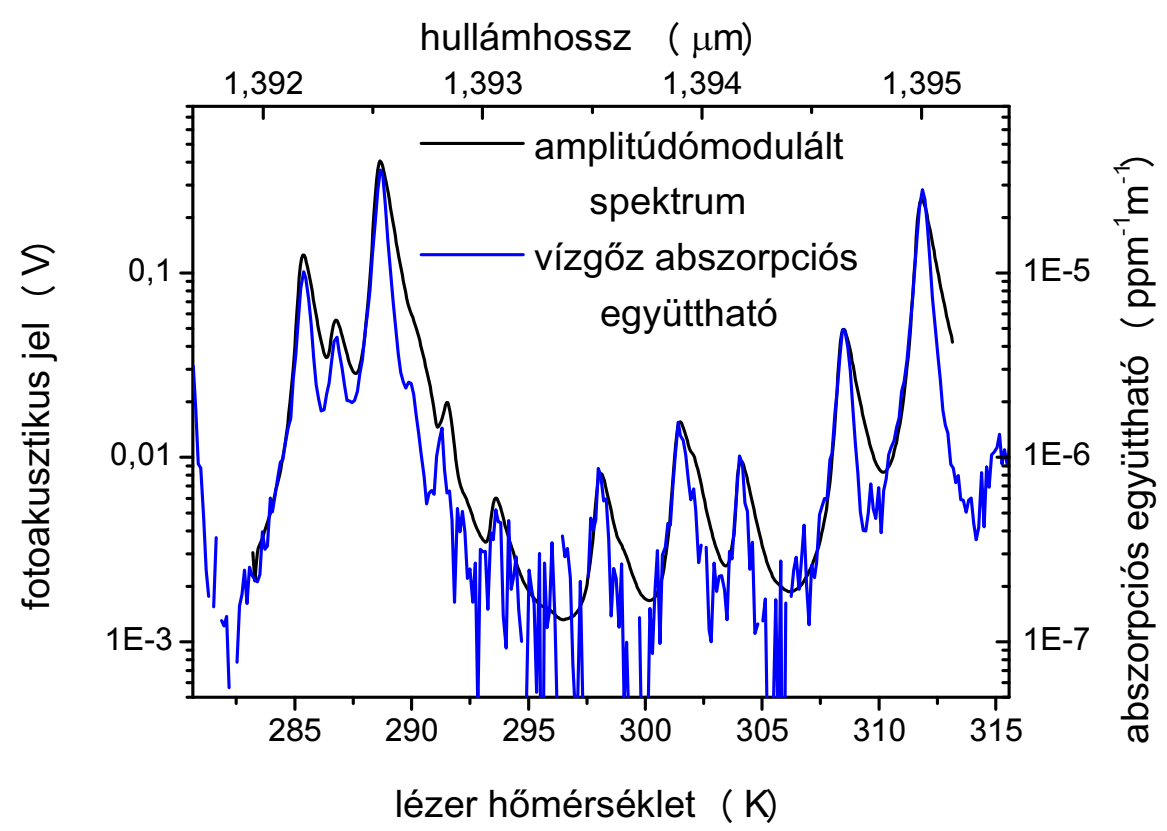

Ábra 43: Mért hullámhosszmodulált spektrum összehasonlítása a PNNL adatbázissal [100].

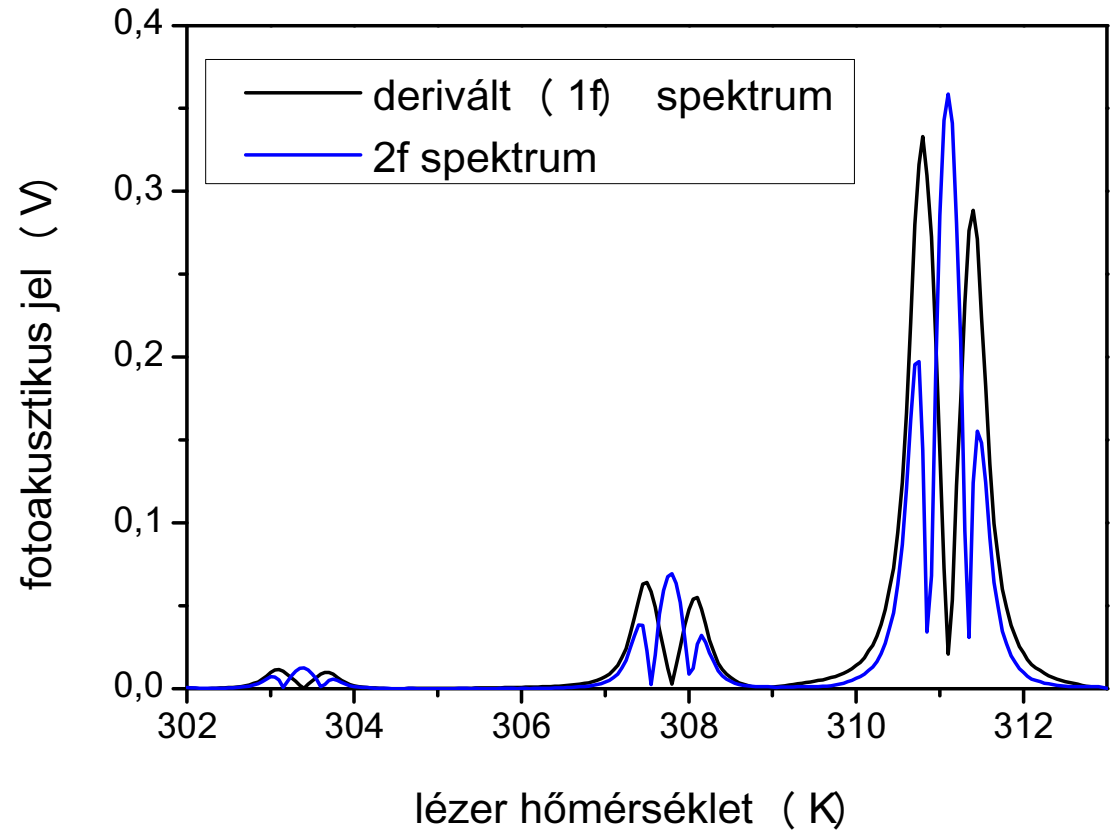

Ábra 44: Hullámhossz-moduláció esetén mért $1 f$ és $2 f$ spektrumok. A $2 f$ spektrumot $50-n e l$ megszoroztam a jobb láthatóságért. 
A kalibráció kiértékelése során a gyengébb elnyelési vonalon elvégzett mérést korrigáltam a teljesítmények arányával és a 45 ábrán található kalibrációs görbét kaptam. A mért PA jel 4,5 nagyságrenden keresztül lineárisan növekszik az abszorpciós együtthatóval, a kalibrációs görbe meredeksége $0,64 \mathrm{~V} / \mathrm{m}$. A mért legnagyobb PA jel mintegy egy nagyságrenddel kisebb, mint a lock-in felső detektálási korlátja, tehát a rendszer dinamikus tartománya legalább 5,5 nagyságrend $1 \mathrm{~s}$ integrálási idővel.

Amikor metánt vezettem a PA kamrába $41,5 \mu \mathrm{V}$ átlagos PA jel mellett $6,15 \mu \mathrm{V}$ zaja volt a mérésnek. A stabilitásteszt Allan deviáció kiértékeléséből (Ábra 46) azt az eredményt kaptam, hogy a rendszerhez tartozó optimális integrálási idő 270 s, amikor a rendszer zaja 200 nV. Felhasználva a korábban meghatározott érzékenység értéket azt kapjuk, hogy a rendszer által kimutatható legkisebb optikai abszorpció változás értéke ( $3 \sigma /$ érzékenység) 2,9 x 10-5 illetve $9,4 \times 10^{-7} \mathrm{~m}^{-1} 1$ illetve $270 \mathrm{~s}$ integrálási idők mellett. A lock-in erősítő felső detektálási küszöbéhez $7 \mathrm{~m}^{-1}$ abszorpciós együttható tartozik, tehát a rendszer dinamikus tartománya PA mérések során 5,8 illetve 7,5 nagyságrend 1 illetve 270 s integrálási idő mellett.

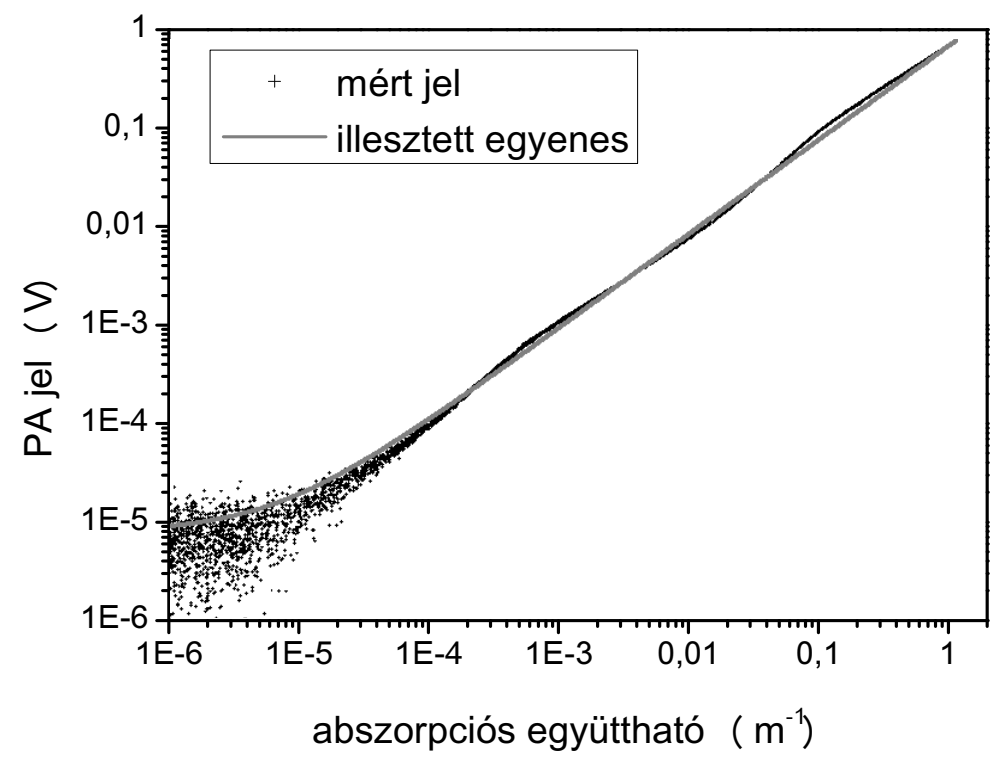

Ábra 45: Az elvégzett kalibráció eredménye. A rendszer érzékenysége 0,64 Vm-1. 


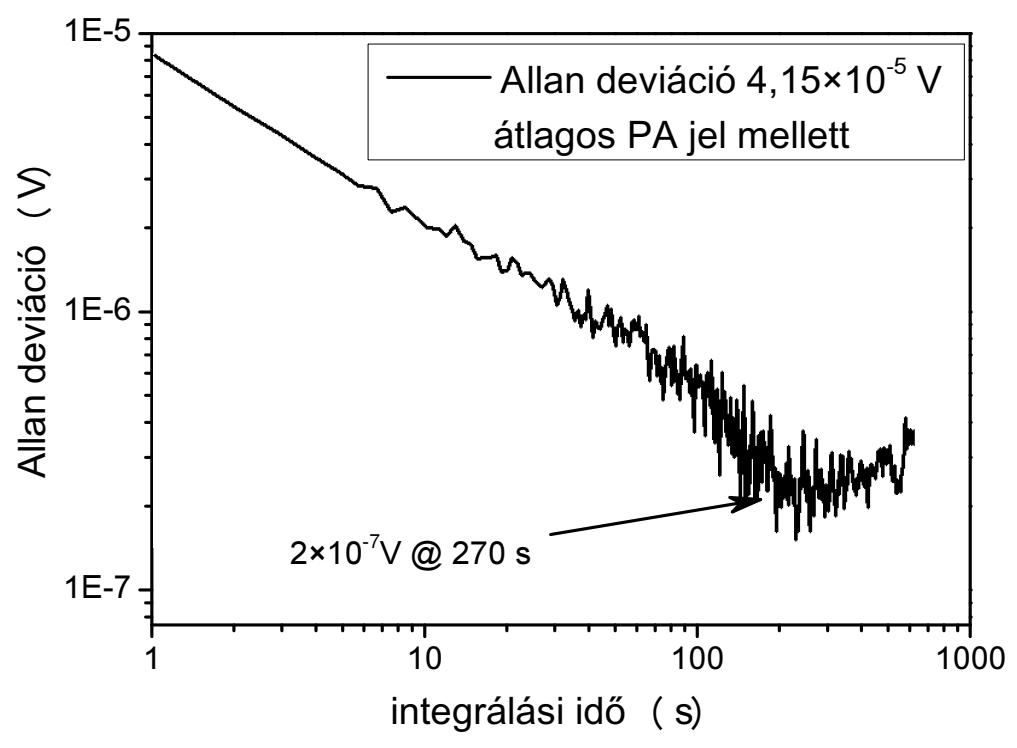

Ábra 46: A mért PA jel Allan deviációja az átlagolási idő függvényében.

\section{9 Összegzés}

A repülőgépes alkalmazások kiterjesztéséhez elengedhetetlenné vált a rendszer lényeges továbbfejlesztése. Ezért az alkalmazott vezérlőelektronika kiváltására egy ipari beágyazott vezérlőre (NI SBRIO 9264) alapozva, PA spektroszkópiai mérésekhez megterveztem és elkészítettem egy új kisméretú és tömegú mérésvezérlő és adatgyújtő rendszer hardverét. A mérőrendszer részeként megterveztem és elkészítettem az összes szükséges perifériát, azaz a feszültségvezérelt lézermeghajtó áramkört, a PI vezérlés alapú lézer hőmérséklet stabilizálást, differenciális mikrofonerősitőt, valamint egyéb kiegészítő szenzorillesztő áramköröket. Az elvégzett tesztek során az összes áramkör kifogástalanul múködött. A korábban használt mérésvezérlő elektronikához képest jelentős előrelépést sikerült elérnem a lézer hőmérsékletének stabilitásában: $1 \mathrm{~m}^{\circ} \mathrm{C}$-ról $0,21 \mathrm{~m}^{\circ} \mathrm{C}$-ra csökkent a hőmérséklet bizonytalansága valamint az érzékenység-váltás nélküli dinamikus tartományt 3,5-ről 5,8 nagyságrendre növeltem. Az új vezérlőelektronikára alapozva a mérőrendszer előreláthatóan 40\%-kal kisebb méretben illetve 50-70\%-kal kisebb tömegben készíthető el. [137]

Megterveztem és LabVIEW fejlesztői környezetben elkészítettem az új mérésvezérlő és adatgyújtő elektronika szoftverét, ami definiálja a rendszer múködését beleértve az összes analóg és digitális ki és bemenet vezérlését, a mikrofonok jeleinek a digitalizálását és lock-in 
eljárással való feldolgozását akár 2(n)f technikával is. Az implementált lock-in erősítő PLL (phase locked loop) alapú jelgenerátoron és szintén PLL alapú demoduláción alapul. Két jelgenerátort (lézer árammeghajtás) és két bemenet (mikrofonerősítő) jelfeldolgozását valósítottam meg: bármelyik jelgenerátorhoz szimultán módon hozzá lehet rendelni bármelyik bemenetet akár 1f, akár $2 \mathrm{f}$ lock-in feldolgozáshoz. A programban jelentős változtatás nélkül ez kibővíthető több jelgenerátorra és bemenet feldolgozására is, akár magasabb rendű harmonikusokon is. A rendszer erőforrásainak alacsony kihasználtsága (60\%) révén, szükség esetén új funkciók, mérési rutinok is implementálhatóak. [137] 


\section{0 Összefoglalás}

\subsection{Bevezetés}

A légköri vízgőz- és teljes víz (azaz vízgőz plusz felhő- eső- és jégcseppek) koncentráció mérés alapvető fontossággal bír a klímakutatásban, hiszen a légköri vízgőz és a felhők az üvegházhatás kb. 75\%-áért felelősek. Ugyanakkor a mérést nehezíti, hogy a légkör nedvességtartalma jelentős tartományban változik: talajszinten (azaz 1 bar nyomáson) a trópusokon akár 40000 ppmV, míg a troposzféra tetején illetve a sztratoszféra alsóbb rétegeiben, azaz 10-12 km-es tengerszint feletti magasságban és 200 mbar körüli nyomáson 1,5 ppmV vízgőz-koncentráció is előfordulhat. Ráadásul a vízgőz koncentrációja mind térben, mind időben általában jelentős inhomogenitásokat mutat; gondoljunk például a gyorsan változó időjárásra. A nagy tér- és időfelbontást megkövetelő atmoszférikus vízgőzmérések egyik lehetséges platformja a menetrend szerint közlekedő repülőgépek, hiszen manapság a repülőgép útvonalak sűrűn behálózzák a Földet. Az ilyen vizsgálatokhoz hozták létre 20 évvel ezelőtt a MOZAIC projektet, melyben kapacitív szenzorok segítségével, utasszállító repülőgépekkel monitorozzák a légkör vízgőz koncentrációját. A közelmúltban indult a hasonló célú IAGOS projekt, amelynek keretein belül a MOZAIC-hoz hasonlóan jelenleg a vízgőz koncentrációját mérik (számos egyéb légköri komponens mellett), de a tervek között szerepel a teljes víztartalom mérése is. Jelenleg a CARIBIC projekt keretein belül végeznek rendszeres vízgőz-koncentráció és teljes víztartalom-mérést, méghozzá a Szegedi Tudományegyetem Optikai és Kvantumelektronikai Tanszéken működő Fotoakusztikus Kutatócsoport által fejlesztett múszerrel, melynek fejlesztésében magam is tevékenyen részt vettem.

Egy repülőgépre telepíthető vízgőz és teljes víztartalom mérő műszerrel szemben alapvető elvárás, hogy:

- A múszer nagyfokú precizitással $(0,3 \mathrm{ppmV}+1 \%$ relatív) és pontossággal (lehetőleg legalább $\pm 5 \%$ relatív) rendelkezzen a repülés alatt előforduló nyomások és koncentrációk mellett. A vízgőz és a teljes víztartalom párhuzamos mérése egyetlen műszerrel legyen kivitelezve, hiszen így a két mennyiség közötti kismértékű eltérés is pontosan mérhető, szemben azzal az esettel, amikor a két mennyiséget két különböző műszer méri. 
- Legyen minél kisebb a múszer válaszideje, mivel csak így biztosítható a repülőgép nagy utazási sebessége mellett a kellő térbeli felbontás.

- A műszer mérete és tömege legyen minél kisebb, minimalizálva a mérés által jelentett többletköltséget a repülőgép üzemanyag-fogyasztásában.

- A múszer folyamatosan és felügyelet nélkül, azaz teljesen automatizáltan, autonóm módon múködjön.

- Legyen ellenálló rázkódásokkal, környezeti zajokkal szemben.

- A kalibrálás, karbantartás iránti igény fél évnél gyakrabban ne vetődjön fel.

- A múszer rendelkezésre-állási ideje legyen gyakorlatilag folyamatos, ami félévenkénti, maximálisan 1 napos kalibrálási, karbantartási időt feltételezve évi 363 nap, azaz 99.45\%.

- A múszer egy későbbi, teljesen kifejlesztett változatának meg kell majd felelnie az igen szigorú repülőgép-ipari biztonsági előírásoknak is.

A kutatócsoportban korábban kifejlesztett és a PA spektroszkópiai mérőrendszerekben alkalmazott vezérlőelektronika egyre kevésbé felelt meg a tudomány, illetve a technika állásának, ami egyre inkább korlátozta a mérőrendszerek szélesebb körű alkalmazását. Ez fokozottan igaz a repülőgépes vízgőzmérő esetében, ahol a minél pontosabb rendszervezérlés mellett a kis méret és tömeg is alapvető fontosságú. A Szegeden kifejlesztett műszer a fenti követelményeknek csak részben felelt meg, ugyanakkor előnyös tulajdonságai kiváló alapot biztosítottak az általam elvégzett továbbfejlesztéshez.

Doktori munkám kezdetén kapcsolódtam be a Fotoakusztikus Kutatócsoport munkájába, feladatom első lépésben a korábbi rendszer hiányosságainak feltérképezése, majd azokra megoldások kidolgozása, megvalósítása volt. Végül igazolnom kellett, hogy az általam kidolgozott megoldások valóban előrelépést jelentettek a rendszer korábbi változatához képest. 


\subsection{Célkitǔzés és a kutatás menete}

Doktori munkám során célul túztem ki a Szegedi Tudományegyetemen kifejlesztett, repülőgépre telepíthető kétcsatornás PA nedvességmérő- múszer megbízhatóságának, pontosságának javítását a teljes múködési tartományában (100-1000 mbar, 1-40000ppmV), a műszer alkalmassá tételét az önálló működésre, valamint a műszer méretének és tömegének jelentős mértékű csökkentését.

Ennek keretein belül:

Új eljárást dolgoztam ki a múszerben alkalmazott diódalézer hullámhosszának precíz és pontos beállítására.

Kidolgoztam egy új, a rendszer pontosságát alapvetően meghatározó kalibrálási ás jelkiértékelési eljárást, melynek segítségével a kalibrálás során alkalmazott referenciaműszerhez képest 2\%-os pontosság érhető el bármely, működési tartományon belüli koncentráció és nyomás esetén.

Elkészítettem egy új mérőrendszert, amely alkalmazásával mind laboratóriumi, mind független összehasonlító tesztek során igazoltam a múszer pontosságát, megbízhatóságát, azaz a korábbi fejlesztéseim eredményeinek gyakorlati alkalmazhatóságát.

A mérőrendszer tömegének és méretének csökkentéséhez elkészítettem egy új, jelentős mértékben méret- és súlycsökkentett mérésvezérlő és adatgyűjtő rendszert.

\section{3 Új tudományos eredmények}

\section{T1: DFB diódalézerek hullámhosszának munkapontra való beállítása pontosságának növelése:}

A kutatócsoport által korábban kidolgozott - elosztott visszacsatolású diódalézerek hullámhosszának beállítására szolgáló - eljárást új, fázistolási görbe inflexiós pontjának meghatározásán alapuló jelkiértékelési algoritmus kifejlesztésével sikerült hozzávetőlegesen egy nagyságrenddel pontosabbá tennem. Kísérletileg igazoltam, hogy az eljárás alkalmazásával a hullámhossz beállítás bizonytalansága $(1 \sigma) 50$ fm értékre csökkenthető (ami $4 \times 10^{-8}$ relatív hullámhossz-bizonytalanságnak felel meg). Továbbá módszert dolgoztam ki, 
amelynek segítségével az eljárás által meghatározott hullámhossz-referencia értékeket megfelelő módon korrigálni lehet, amennyiben a légköri nyomás megváltozik. Megállapítottam, hogy hozzávetőlegesen 10 mbar nyomásváltozás okoz akkora eltérést, amelynél a korrekciós módszert már alkalmazni szükséges. Megjegyzendő, hogy a kidolgozott új eljárás precizitása révén alkalmas az elnyelési vonalak ütközési eltolódásának a vizsgálatára is.

T2: Kalibrációs és jelkiértékelési eljárás fejlesztése kétcsatornás fotoakusztikus vízgőzkoncentráció- mérő rendszerhez:

Kidolgoztam egy új kalibrálási és jelkiértékelési eljárást, amely a nyomás-koncentráció-PA jel térben kifeszülő kalibrációs felület kísérleti meghatározásán alapul az alábbiak szerint: különböző, de konstans nyomásokon kell meghatározni a koncentráció függvényében a PA jel nagyságát. A különböző nyomásokon kapott kalibrációs görbéket felhasználva a pillanatnyi nyomás és a PA jel nagyságából egy interpolációs eljárással lehet meghatározni a koncentráció pontos értékét. A bemutatott eljárás alkalmazásával, a PA mérőrendszerrel mért koncentrációk zajszint $\pm 2 \%$-on belül megegyeznek a kalibrálás során alkalmazott referenciamúszer értékeivel 100-1000 mbar nyomás és 0,5-25000 ppmV koncentrációtartományon belül, szemben a korábban alkalmazott eljárással, amelynek pontossága ugyanilyen körülmények között (a nyomástól és a koncentrációtól függően) akár egy nagyságrenddel is rosszabb volt. Korábban, a méréseknek ezt a pontosságát a változó nyomás mellett nem lehetett megvalósítani. További előnye az új eljárásnak, hogy az adatok kiértékelése néhány milliszekundum időt vesz igénybe mérési pontonként, így valós idejü jelkiértékelésre is lehetőség van.

T3: 4. Új mérőrendszer elkészítése, pontosságának, megbízhatóságának igazolása mind laboratóriumi, mind pedig repülőgépes összehasonlító mérések során:

Megterveztem és elkészítettem egy új kétcsatornás vízgőz-koncentráció- mérő- rendszert, melyben implementáltam az 1. és 2 . tézispontokban bemutatott eljárásokat. A mérőrendszert független összehasonlító mérések során teszteltem mind laboratóriumi, mind repülőgépes mérések során. Mindkét esetben a széles mérési tartomány miatt két műszert kellett referenciaként használnom, egyet alacsony, egyet pedig magas koncentrációk esetén. Az új mérőrendszer az összes mérés során megbízhatóan, a referencia-múszerekhez képest 
tipikusan 5\%-on belüli eltéréssel múködött a teljes vizsgált nyomás és koncentráció tartományon. A mérőrendszer fejlesztése során hasonló pontosságot korábban nem sikerült elérni

T4: Mérésvezérlő és adatgyứjtő rendszer hardverének tervezése és elkészítése fotoakusztikus spektroszkópiai mérésekhez:

A repülőgépes alkalmazások kiterjesztéséhez elengedhetetlenné vált a rendszer lényeges továbbfejlesztése. Ezért az alkalmazott vezérlőelektronika kiváltására egy ipari beágyazott vezérlőre (NI SBRIO 9264) alapozva, PA spektroszkópiai mérésekhez megterveztem és elkészítettem egy új kisméretű és tömegű mérésvezérlő és adatgyűjtő rendszer hardverét. $A$ mérőrendszer részeként megterveztem és elkészítettem az összes szükséges perifériát, azaz a feszültségvezérelt lézermeghajtó áramkört, a PI vezérlés alapú lézer hőmérséklet stabilizálást, differenciális mikrofonerősítőt, valamint egyéb kiegészítő szenzorillesztő áramköröket. Az elvégzett tesztek során az összes áramkör kifogástalanul múködött. A korábban használt mérésvezérlő elektronikához képest jelentős előrelépést sikerült elérnem a lézer hőmérsékletének stabilitásában: $1 \mathrm{~m}^{\circ} \mathrm{C}$-ról $0,21 \mathrm{~m}^{\circ} \mathrm{C}$-ra csökkent a hőmérséklet bizonytalansága valamint az érzékenység-váltás nélküli dinamikus tartományt 3,5-ről 5,8 nagyságrendre növeltem. Az új vezérlőelektronikára alapozva a mérőrendszer előreláthatóan 40\%-kal kisebb méretben illetve 50-70\%-kal kisebb tömegben készíthető el.

T5: Mérésvezérlő és adatgyűjtő rendszer szoftverének tervezése és elkészítése fotoakusztikus spektroszkópiai mérésekhez:

Megterveztem és LabVIEW fejlesztői környezetben elkészítettem az új mérésvezérlő és adatgyűjtő elektronika szoftverét, ami definiálja a rendszer múködését beleértve az összes analóg és digitális ki és bemenet vezérlését, a mikrofonok jeleinek a digitalizálását és lock-in eljárással való feldolgozását akár 2(n)f technikával is. Az implementált lock-in erősítő PLL (phase locked loop) alapú jelgenerátoron és szintén PLL alapú demoduláción alapul. Két jelgenerátort (lézer árammeghajtás) és két bemenet (mikrofonerősítő) jelfeldolgozását valósítottam meg: bármelyik jelgenerátorhoz szimultán módon hozzá lehet rendelni bármelyik bemenetet akár 1f, akár $2 \mathrm{f}$ lock-in feldolgozáshoz. A programban jelentős változtatás nélkül ez kibővíthető több jelgenerátorra és bemenet feldolgozására is, akár magasabb rendű 
harmonikusokon is. A rendszer erőforrásainak alacsony kihasználtsága (60\%) révén, szükség esetén új funkciók, mérési rutinok is implementálhatóak.

\subsection{A fejlesztések során elért eredmények}

Doktori munkám során a kitúzött célokat, - azaz, hogy a kétcsatornás nedvesség-mérő múszer

- megbízhatóságát, pontosságát javítsam a teljes múködési tartományában (azaz a 150-1000 mbar légköri nyomás és a 1-40000 ppmV vízgőz-koncentrációtartományban);

- azt alkalmassá tegyem az önálló, teljes mértékben automatizált múködésre;

- annak méretét és tömegét számottevő mértékben csökkentsem, ezáltal is elősegítve gyakorlati alkalmazhatóságát, elfogadottságát; -

sikerült elérnem. A fontosabb, számszerűsíthető jellemzőket az alábbi táblázatban (Táblázat 9) foglaltam össze, összehasonlítva a munkám kezdetén az SZTE1 és CARIBIC2 rendszerekre jellemzőkkel. 


\begin{tabular}{|c|c|c|}
\hline $\begin{array}{l}\text { rendszerjellemző } \\
\text { paraméterek }\end{array}$ & SZTE1 és CARIBIC2 rendszerek & új fejlesztések eredményei \\
\hline $\begin{array}{c}\text { lézer hőmérsékletének } \\
\text { stabilitása }\end{array}$ & $1 \mathrm{~m}^{\circ} \mathrm{C}$ & $0,21 \mathrm{~m}^{\circ} \mathrm{C}$ \\
\hline $\begin{array}{l}\text { lézer hőmérséklete } \\
\text { beállításának felbontása }\end{array}$ & $10 \mathrm{~m}^{\circ} \mathrm{C}$ & $0,5 \mathrm{~m}^{\circ} \mathrm{C}$ \\
\hline $\begin{array}{c}\text { hullámhossz-beállítás } \\
\text { precizitása }\end{array}$ & $470 \mathrm{fm}$ & $50 \mathrm{fm}$ \\
\hline alsó detektálási küszöb & $<0,5 \mathrm{ppmV}$ & $<0,5 \mathrm{ppmV}$ \\
\hline felső detektálási küszöb & $\begin{array}{c}35000 \text { ppmV (AD-konverter } \\
\text { dinamikus tartománya által } \\
\text { limitálva) }\end{array}$ & $\begin{array}{c}60000 / 400000 \text { ppmV } \\
\text { (kondenzáció } 45^{\circ} \mathrm{C} \text { múszer } \\
\text { hőmérséklet mellett/ } \\
\text { fotoakusztika által limitált } \\
\text { becsült érték) }\end{array}$ \\
\hline $\begin{array}{l}\text { pontos múködés } \\
\text { tartománya (kalibrációs } \\
\text { referencia-múszer által } \\
\text { limitálva) }\end{array}$ & 1-20000 ppmV & 1-20000 ppmV \\
\hline $\begin{array}{c}\text { megbízható koncentráció- } \\
\text { meghatározás } \\
\text { nyomástartománya }\end{array}$ & egy definiált nyomásérték & 100-1050 mbar \\
\hline $\begin{array}{c}\text { koncentráció } \\
\text { meghatározás módja }\end{array}$ & utólag megvalósítható & $\begin{array}{l}\text { valós időben, akár az elkészített } \\
\text { új mérésvezérlő és adatgyűjtő } \\
\text { elektronikába programozva }\end{array}$ \\
\hline méret & $19^{\prime \prime} \times 18^{\prime \prime}$ x 3 U rack & $19^{\prime \prime} \times 11^{\prime \prime}$ x 3 U rack \\
\hline tömeg (pumpa nélkül) & 15 kg (plusz adatrögzítő) & 5-6 kg (becsült érték) \\
\hline
\end{tabular}

Táblázat 9: A fejlesztések során elért legfontosabb eredmények számszerüsítése. 


\subsection{A tézisekhez kapcsolódó publikációk:}

T1:

D. Tátrai, Z. Bozóki and G. Szabó

Method for wavelength locking of tunable diode lasers based on photoacoustic spectroscopy

Optical Engineering 59096104.

10.1117/1.OE.52.9.096104

IF: 0.958

Z. Bozóki, D. Tátrai, G. Szabó:

Eljárás és összeállítás hullámhossz-hangolható fényforrás hullámhosszának stabilizálására abszorpciós spektroszkópiai jeldetektálás alapján

Magyar szabadalom

Bejelentve: 2011.12.23.

Elfogadva: 2015.05.27.

Lajstromszám: 230073

T2, T3: D. Tátrai, Z. Bozóki, H. Smit, C. Rolf, N. Spelten, M. Krämer, A. Filges, C. Gerbig, G. Gulyás, and G. Szabó

Dual-channel photoacoustic hygrometer for airbornemeasurements: background, calibration, laboratory and in-flight intercomparison tests

Atmos. Meas. Tech., 8, 1-10, 2015

www.atmos-meas-tech.net/8/1/2015/

doi:10.5194/amt-8-1-2015

IF: $3.206(2013)$

T4, T5: $\quad$ D.Tatrai, Z. Bozoki, G. Gulyas, G. Szabo

Embedded system based data acquisition and control system for photoacoustic spectroscopic applications

Measurement, Volume 63, March 2015, Pages 259-268

doi:10.1016/j.measurement.2014.12.028

IF: $1.526(2013)$ 


\section{Summary}

\subsection{Introduction}

Airborne hygrometry (measuring water vapor concentration and total water content) has a very important role in climate research as atmospheric moisture is responsible for circa $75 \%$ of greenhouse effect. High variety of humidity levels means one of the difficulties of such measurements: it can be as high as $40000 \mathrm{ppmV}$ at ground level (namely at 1 bar pressure) at tropics and as low as $1.5 \mathrm{ppmV}$ at the upper troposphere-lower stratosphere (namely at 10-12 $\mathrm{km}$ altitude, at circa 200 mbar pressure). Moreover, atmospheric humidity is usually inhomogenously distributed both in time and space - one can think the rapidly varying meteorological circumstances. The MOZAIC project was launched 20 years ago to measure atmospheric water vapor concentration with capacitive sensors mounted on in-service aircrafts. The IAGOS project was recently launched to similarly to measure atmospheric water vapor concentration (besides several other compounds) similarly as it has been done within the MOZAIC project, but extending the measurements to total water content is also planned. Atmospheric water vapor concentration and total water content is regularly measured within the CARIBIC project with the measuring system developed at the University of Szeged, Department of Optics and Quantum Electronics, Research Group on Photoacoustic Spectroscopy, partially by myself.

An airborne water vapor concentration and total water content measuring system has to meet several expectations:

- It has to measure highly precise (at least $0.3 \mathrm{ppmV}+1 \%$ relative) and accurate (at least $\pm 5 \%$ relative) at any pressures and concentrations possible during a flight.

- Measurement of water vapor concentration and total water content should be realized in one measuring system since this way small differences of the two quantities can be measured more accurately than with two separate systems.

- The high cruising velocity requires fast response time to provide high space resolution.

- The measuring system has to be small in size and light in weight to minimalize the operational costs.

- The system has to operate continuously in a fully autonomous way.

- Maintenance and recalibration interval should be at least half a year. 
- The availability should be quasi continuous: 363 days a year (namely $99.54 \%$ ) supposing 1 day maintenance every half year.

- Has to meet all the rigorous safety restrictions.

The data acquisition and control system that previously had been developed in the research group less and less met the state of the technology and science more and more limiting the broader applicability of our systems. This was also true in the case of airborne hygrometry, where besides the state of the art system control the los size and weight are also essential. The measuring system that had been developed at Szeged only partially met the requirements listed above, but was a good starting point for the improvements done by myself.

I joined the Photoacoustic Research Group at the beginning of my doctoral studies, duties were exploring the shortcomings of the system, finding and implementing solutions on them. Finally I had to prove that the developments achieved by myself result in a significant performance improvement.

\subsection{Objectives and methods}

My aim was improving the reliability and accuracy of the two channel airborne hygrometer developed at the University of Szeged and making it capable for autonomous operation while reducing its size and weight.

Within this:

I developed a new method for setting the wavelength of the laser applied in the system with high precision and accuracy.

I developed a new calibration and data processing technique, which determines the accuracy of the system that makes it traceable to the calibration reference within $2 \%$ at any pressures and concentrations in the operational range.

I prepared a new measuring system and proved the applicability of the previous developments and its reliability and accuracy through independent laboratory and in-flight inter comparison measurements.

I prepared a new data acquisition and control system to reduce the size and weight of the measuring system itself. 


\subsection{Novel scientific results}

T1: Improvement of the accuracy of setting the wavelength of DFB diode lasers to the targeted one:

I managed to increase the precision and accuracy of the technique previously had been developed by the research group for setting the wavelength of DFB diode lasers by circa one order of magnitude through developing a data processing algorithm for the determination of the inflection point of the phase shift curve. Through experiments I proved that the uncertainty $(1 \sigma)$ of the new technique is $50 \mathrm{fm}$. I ascertained that the new technique requires pressure correction and determined its level: approximately 10 mbar pressure variation makes the correction necessary. Note: The precision of the new technique through its precision enables the study of the pressure dependent shift of absorption lines.

T2: Development of calibration and data processing technique for the two channel hygrometer system:

I developed a new calibration and data processing technique based on the determination of the calibration surface in the pressure- concentration- photoacoustic signal space: the photoacoustic signal as the function of concentration has to be determined at various but constant pressure levels. From the present photoacoustic signal and pressure using the constant pressure calibration curves I determine the concentration value using an interpolation technique. Using this technique the photoacoustic system is traceable to the calibration reference within noise level $\pm 2 \%$ in the $0.5-25000 \mathrm{ppmV}$ concentration and 100 1000 mbar pressure ranges. Previously this level of accuracy was not possible at various pressures. The data processing interval is only a few milliseconds therefore real-time data processing is possible now.

T3: Preparation of a new measuring system and proving its accuracy and reliability through laboratory and in-flight inter comparison measurements.

I designed and prepared a new two channel hygrometer system in which I also implemented the techniques introduced in T1 and T2. I tested the system through blind laboratory and inflight inter comparison measurements. At both tests due to the high dynamic range I had to use two reference instruments one at low and one at high concentrations. The measuring 
system was performing reliably during the tests, in comparison to the reference instruments it measured values typically with $5 \%$ or less relative deviation. During the development of the system similar result never had been achieved previously.

T4: Designing and preparing the hardware of a data acquisition and control system for photoacoustic spectroscopic measurements:

In order to extend the application area of the airborne measurements the improvement of the entire measuring system became necessary. Therefore, to replace the controlling electronics based on an industry standard embedded controller (NI SBRIO9642) I designed and prepared a new small in size and low in weight data acquisition and control system. As part of the system I also designed and prepared all the necessary peripherals such as voltage controlled laser driver, PI control based laser temperature stabilization, differential microphone amplifier, and other sensor signal conditioning circuits. I managed to achieve significant advancement in the laser temperature stabilization: reduced the uncertainty from $1 \mathrm{~m}^{\circ} \mathrm{C}$ to $0.21 \mathrm{~m}^{\circ} \mathrm{C}$ and in the dynamic range (without sensitivity change): I increased it from 3.5 to 5.8 orders of magnitude. Furthermore, based on this new data acquisition and control system the measurement system probably can be prepared $40 \%$ smaller in size and $50-70 \%$ lighter.

T5: Designing and preparing the software of a data acquisition and control system for photoacoustic spectroscopic measurements:

I designed and prepared the software of the new data acquisition and control system in LabVIEW development environment: It defines the functionality of the hardware including all the analogue and digital in/output channels, digitalizing and lock-in evaluating the signals of the microphones even using $2(n) f$ technique. The implemented lock-in amplifier is based on PLL (phase locked loop) signal generation and demodulation. I implemented two signal generators (laser control signals) and the data evaluation of two input channels (microphone amplifiers): Any of the signal generators can be assigned to any of the input channels in parallel using $1 \mathrm{f}$ or $2 \mathrm{f}$ lock-in data processing. Without significant modification of the software the system can be extended for more signal generators and input channels as well even at higher harmonics. The usage of the system resources is low (60\%) therefore new functions measuring routines can be implemented upon need. 


\subsection{Achieved results}

During my doctoral work I managed achieving the targeted objectives in developing a two channel hygrometer system:

- I increased its reliability and accuracy in its entire operation range (1-40000 ppmV concentration and 150-1000 mbar).

- I made it capable for autonomous, fully automated operation.

- I significantly reduced its size and weight helping its broader accept and usage.

I listed the more important system properties in the following table (Table 1) in comparison to the ones that were specific to the SZTE1 and CARIBIC2 systems at the beginning of my work. 


\begin{tabular}{|c|c|c|}
\hline system properties & SZTE1 \& CARIBIC2 systems & results of my developments \\
\hline $\begin{array}{l}\text { stability of laser } \\
\text { temperature }\end{array}$ & $1 \mathrm{~m}^{\circ} \mathrm{C}$ & $0,21 \mathrm{~m}^{\circ} \mathrm{C}$ \\
\hline $\begin{array}{l}\text { resolution of laser } \\
\text { temperature setting }\end{array}$ & $10 \mathrm{~m}^{\circ} \mathrm{C}$ & $0,5 \mathrm{~m}^{\circ} \mathrm{C}$ \\
\hline $\begin{array}{c}\text { precision of wavelength } \\
\text { setting }\end{array}$ & $470 \mathrm{fm}$ & $50 \mathrm{fm}$ \\
\hline lower detection limit & $<0,5 \mathrm{ppmV}$ & $<0,5 \mathrm{ppmV}$ \\
\hline upper detection limit & $\begin{array}{c}35000 \text { ppmV (limited by the } \\
\text { dynamic range of the A/D } \\
\text { converter) }\end{array}$ & $\begin{array}{c}60000 / 400000 \mathrm{ppmV} \\
\text { (condensation at } 45^{\circ} \mathrm{C} \text { system } \\
\text { temperature/ estimated limit } \\
\text { based on absorption } \\
\text { coefficient) }\end{array}$ \\
\hline $\begin{array}{c}\text { range of accurate } \\
\text { measurements (limited by } \\
\text { calibration reference) }\end{array}$ & $1-25000 \mathrm{ppmV}$ & $1-25000 \mathrm{ppmV}$ \\
\hline $\begin{array}{l}\text { range of reliable } \\
\text { concentration } \\
\text { determination }\end{array}$ & one defined pressure & 100-1050 mbar \\
\hline $\begin{array}{l}\text { concentration } \\
\text { determination }\end{array}$ & post-processing only & $\begin{array}{c}\text { realtime, can be implemented } \\
\text { in the new data acquisition and } \\
\text { control system }\end{array}$ \\
\hline size & $19^{\prime \prime} \times 18^{\prime \prime}$ x 3 U rack & $19^{\prime \prime} \times 11^{\prime \prime} \times 3$ rack \\
\hline weight (without pump) & $\begin{array}{c}15 \mathrm{~kg} \text { (extra data logger is } \\
\text { necessary) }\end{array}$ & 5-6 kg (estimated) \\
\hline
\end{tabular}

Table 1: Summary of the most relevant achieved results. 


\subsection{Related publications}

T1:

D. Tátrai, Z. Bozóki and G. Szabó

Method for wavelength locking of tunable diode lasers based on photoacoustic spectroscopy

Optical Engineering 59096104.

10.1117/1.OE.52.9.096104

IF: 0.958

Z. Bozóki, D. Tátrai, G. Szabó:

Method and arrangement for wavelength monitoring of wavelength tunable light source and stabiliziing based on absorption spectroscopic detecting Hungarian Patent

Date of submission: 2011.12.23.

Date of acceptance: 2015.05.27.

Patent No: 230073

T2, T3: D. Tátrai, Z. Bozóki, H. Smit, C. Rolf, N. Spelten, M. Krämer, A. Filges, C. Gerbig, G. Gulyás, and G. Szabó

Dual-channel photoacoustic hygrometer for airbornemeasurements: background, calibration, laboratory and in-flight intercomparison tests

Atmos. Meas. Tech., 8, 1-10, 2015

www.atmos-meas-tech.net/8/1/2015/

doi:10.5194/amt-8-1-2015

IF: $3.206(2013)$

T4, T5: $\quad$ D.Tatrai, Z. Bozoki, G. Gulyas, G. Szabo

Embedded system based data acquisition and control system for photoacoustic spectroscopic applications

Measurement, Volume 63, March 2015, Pages 259-268

doi:10.1016/j.measurement.2014.12.028

IF: 1.526 (2013) 


\section{Köszönetnyilvánítás}

Szeretnék köszönetet mondani témavezetőimnek, Prof. Dr. Szabó Gábornak és Dr. Bozóki Zoltánnak, hogy biztosították a munkavégzéshez szükséges feltételeket, hogy munkám során ötleteikkel, javaslataikkal segítettek. Köszönettel tartozok az Optikai és Kvantumelektronikai Tanszék vezetőinek, Prof. Dr. Rácz Bélának, Dr. Osvay Károlynak és Prof. Dr. Hopp Bélának, hogy biztosították a munkám elvégzéséhez szükséges feltételeket.

Köszönettel tartozok Dr. Andreas Zahn-nak a CARIBIC projektben alkalmazott mérőrendszerünkkel kapcsolatos kritikai észrevételeiért, melyek nagy segítséget nyújtottak a rendszer fejlesztése során. Köszönettel tartozok Dr. Herman Smitnek, Dr. Cornelius Schillernek ${ }^{\dagger}$, Dr. Martina Kraemernek, valamint Dr. Chrisoph Gerbignek hogy laboratóriumi és repülőgépes mérési kampányok során az általuk vezetett kutatócsoportokkal dolgozhattam. Köszönettel tartozok Rolf Masernak és a teljes Enviscope csapatnak a repülőgépes mérések során nyújtott segítségüknek.

Köszönettel tartozok a National Instruments Hungary Kft-nek, hogy tesztelésre rendelkezésemre bocsájtottak egy CRIO rendszert.

A munkámat az alábbi projektek támogatták:

EU FP7 EUFAR N 227159

TÁMOP-4.2.2.A-11/1/KONV-2012-0047

OTKA, NN109679

TÁMOP 4.2.4.A/2-11-1-2012-0001 


\section{Hivatkozások}

1. http://www.esrl.noaa.gov/gmd/ccgg/trends/, Megtekintve: 2015. 06. 10.

2. http://icp.giss.nasa.gov/education/methane/lessons/, Megtekintve: 2015. 06. 10.

3. Rosenlof, K.H., S.J. Oltmans, D. Kley, J.M. Russell, E.W. Chiou, W.P. Chu, D.G. Johnson, K.K. Kelly, H.A. Michelsen, G.E. Nedoluha, E.E. Remsberg, G.C. Toon, and M.P. McCormick, Stratospheric water vapor increases over the past half-century. Geophysical Research Letters, 2001. 28(7): p. 1195-1198, DOI: 10.1029/2000GL012502

4. Burkhardt, U., B. Kärcher, and U. Schumann, Global Modeling of the Contrail and Contrail Cirrus Climate Impact. Bulletin of the American Meteorological Society, 2010. 91(4): p. 479-484, DOI: 10.1175/2009bams2656.1

5. Burkhardt, U. and B. Kärcher, Global radiative forcing from contrail cirrus. Nature Climate Change, 2011. 1(1): p. 54-58, DOI: 10.1038/nclimate1068

6. Boucher, O., Atmospheric science: Seeing through contrails. Nature Climate Change, 2011. 1(1): p. 24-25, DOI: 10.1038/nclimate1078

7. Yi, B., P. Yang, K.-N. Liou, P. Minnis, and J.E. Penner, Simulation of the global contrail radiative forcing: A sensitivity analysis. Geophysical Research Letters, 2012. 39(24), DOI: 10.1029/2012gl054042

8. Xie, Y., P. Yang, K.-N. Liou, P. Minnis, and D.P. Duda, Parameterization of contrail radiative properties for climate studies. Geophysical Research Letters, 2012. 39(24), DOI: 10.1029/2012gl054043

9. Meerkötter, R., U. Schumann, D.R. Doelling, P. Minnis, T. Nakajima, and Y. Tsushima, Radiative forcing by contrails. Ann. Geophys., 0001. 17(8): p. 1080-1094, DOI: 10.1007/s00585-999-1080-7

10. Jeßberger, P., C. Voigt, U. Schumann, I. Sölch, H. Schlager, S. Kaufmann, A. Petzold, D. Schäuble, and J.F. Gayet, Aircraft type influence on contrail properties. Atmospheric Chemistry and Physics, 2013. 13(23): p. 11965-11984, DOI: 10.5194/acp-13-119652013

11. Marvel, K., B. Kravitz, and K. Caldeira, Geophysical limits to global wind power. Nature Climate Change, 2012. 3(2): p. 118-121, DOI: 10.1038/nclimate1683

12. Jacobson, M.Z. and C.L. Archer, Saturation wind power potential and its implications for wind energy. Proc Natl Acad Sci U S A, 2012. 109(39): p. 15679-84, DOI: 10.1073/pnas.1208993109

13. Fix, A., G. Ehret, H. Flentje, G. Poberaj, M. Gottwald, H. Finkenzeller, H. Bremer, M. Bruns, J.P. Burrows, A. Kleinböhl, H. Küllmann, J. Kuttippurath, A. Richter, P. Wang, K.P. Heue, U. Platt, I. Pundt, and T. Wagner, SCIAMACHY validation by aircraft remote sensing: design, execution, and first measurement results of the SCIA-VALUE mission. Atmospheric Chemistry and Physics, 2005. 5(5): p. 1273-1290, DOI: 10.5194/acp-51273-2005

14. http://www.esrl.noaa.gov/gmd/ccgg/aircraft/, Megtekintve: 2015. 06. 10.

15. http://www.enviscope.de/measurement-campaigns/, Megtekintve: 2015. 06. 10. 
16.

http://www.safire.fr/web/index.php?option=com content\&view=article\&id= 20\&Itemid=22\&lang=en, Megtekintve: 2015. 06. 10.

17. Marenco, A., V. Thouret, P. Nédélec, H. Smit, M. Helten, D. Kley, F. Karcher, P. Simon, K. Law, J. Pyle, G. Poschmann, R. Von Wrede, C. Hume, and T. Cook, Measurement of ozone and water vapor by Airbus in-service aircraft: The MOZAIC airborne program, an overview. Journal of Geophysical Research: Atmospheres, 1998. 103(D19): p. 2563125642, DOI: 10.1029/98JD00977

18. Brenninkmeijer, C.A.M., P. Crutzen, F. Boumard, T. Dauer, B. Dix, R. Ebinghaus, D. Filippi, H. Fischer, H. Franke, U. Frieß, J. Heintzenberg, F. Helleis, M. Hermann, H.H. Kock, C. Koeppel, J. Lelieveld, M. Leuenberger, B.G. Martinsson, S. Miemczyk, H.P. Moret, H.N. Nguyen, P. Nyfeler, D. Oram, D. O'Sullivan, S. Penkett, U. Platt, M. Pupek, M. Ramonet, B. Randa, M. Reichelt, T.S. Rhee, J. Rohwer, K. Rosenfeld, D. Scharffe, H. Schlager, U. Schumann, F. Slemr, D. Sprung, P. Stock, R. Thaler, F. Valentino, P. van Velthoven, A. Waibel, A. Wandel, K. Waschitschek, A. Wiedensohler, I. Xueref-Remy, A. Zahn, U. Zech, and $\mathrm{H}$. Ziereis, Civil Aircraft for the regular investigation of the atmosphere based on an instrumented container: The new CARIBIC system. Atmos. Chem. Phys., 2007. 7(18): p. 4953-4976, DOI: 10.5194/acp-7-4953-2007

19. Szakáll, M., Z. Bozóki, Á. Mohácsi, A. Varga, and G. Szabó, Diode Laser Based Photoacoustic Water Vapor Detection System for Atmospheric Research. Applied Spectroscopy, 2004. 58(7): p. 792-798, DOI: 10.1366/0003702041389373

20. http://www.iagos.org/IAGOS, Megtekintve: 2015. 06. 10.

21. http://www.hilase.hu/index.php/measurement-service/atmospheric-humidity, Megtekintve: 2015. 06. 10.

22. http://www.spectrasensors.com/wvss, Megtekintve: 2015. 06. 10.

23. http://www.hygrometers.com/products/cr-2/, Megtekintve: 2015. 06. 10.

24. http://www.specim.fi/index.php/products/airborne, Megtekintve: 2015. 06. 10.

25. http://www.dropletmeasurement.com/products/airborne.html, Megtekintve: 2015. 06. 10.

26. http://www.picarro.com/products solutions/gas analyzers/flight co co2 ch4 h2o, Megtekintve: 2015. 06. 10.

27. McFarquhar, G., B. Schmid, A. Korolev, J.A. Ogren, P.B. Russell, J. Tomlinson, D.D. Turner, and W. Wiscombe, Airborne Intrumentation Needs for Climate and Atmospheric Research. Bulletin of the American Meteorological Society, 2011. 92(9): p. 1193-1196, DOI: 10.1175/2011BAMS3180.1

28. http://www.arm.gov/cms/?s=AVP+Aircraft+Instrumentation, Megtekintve: 2015. 06. 10.

29. May, R.D. and C.R. Webster, Data processing and calibration for tunable diode laser harmonic absorption spectrometers. Journal of Quantitative Spectroscopy and Radiative Transfer, 1993. 49(4): p. 335-347, DOI: 10.1016/0022-4073(93)90098-3

30. Weinstock, E.M., E.J. Hintsa, A.E. Dessler, J.F. Oliver, N.L. Hazen, J.N. Demusz, N.T. Allen, L.B. Lapson, and J.G. Anderson, New fast response photofragment fluorescence 
hygrometer for use on the NASA ER-2 and the Perseus remotely piloted aircraft. Review of Scientific Instruments, 1994. 65(11): p. 3544-3554, DOI: 10.1063/1.1144536

31. Yushkov, V., V. Astakhov, and S. Merkulov. Optical balloon hygrometer for uppertroposphere and stratosphere water vapor measurements. 1998. DOI: $10.1117 / 12.317759$

32. Durry, G., N. Amarouche, L. Joly, X. Liu, B. Parvitte, and V. Zéninari, Laser diode spectroscopy of $\mathrm{H} 2 \mathrm{O}$ at $2.63 \mu \mathrm{m}$ for atmospheric applications. Applied Physics B, 2008. 90(3-4): p. 573-580, DOI: 10.1007/s00340-007-2884-3

33. Zöger, M., A. Afchine, N. Eicke, M.T. Gerhards, E. Klein, D.S. McKenna, U. Mörschel, U. Schmidt, V. Tan, F. Tuitjer, T. Woyke, and C. Schiller, Fast in situ stratospheric hygrometers: A new family of balloon-borne and airborne Lyman $\alpha$ photofragment fluorescence hygrometers. Journal of Geophysical Research: Atmospheres, 1999. 104(D1): p. 1807-1816, DOI: 10.1029/1998JD100025

34. Buchholz, B., B. Kühnreich, H.G.J. Smit, and V. Ebert, Validation of an extractive, airborne, compact TDL spectrometer for atmospheric humidity sensing by blind intercomparison. Applied Physics B, 2013. 110(2): p. 249-262, DOI: 10.1007/s00340012-5143-1

35. Thornberry, T.D., A.W. Rollins, R.S. Gao, L.A. Watts, S.J. Ciciora, R.J. McLaughlin, and D.W. Fahey, A two-channel, tunable diode laser-based hygrometer for measurement of water vapor and cirrus cloud ice water content in the upper troposphere and lower stratosphere. Atmos. Meas. Tech., 2015. 8(1): p. 211-224, DOI: 10.5194/amt-8-2112015

36. http://www.eufar.net/, Megtekintve: 2015. 06. 10.

37. http://science.nasa.gov/missions/oracles/, Megtekintve: 2015. 06. 10.

38. Baumgardner, D., J.L. Brenguier, A. Bucholtz, H. Coe, P. DeMott, T.J. Garrett, J.F. Gayet, M. Hermann, A. Heymsfield, A. Korolev, M. Krämer, A. Petzold, W. Strapp, P. Pilewskie, J. Taylor, C. Twohy, M. Wendisch, W. Bachalo, and P. Chuang, Airborne instruments to measure atmospheric aerosol particles, clouds and radiation: A cook's tour of mature and emerging technology. Atmospheric Research, 2011. 102(1-2): p. 10-29, DOI: 10.1016/j.atmosres.2011.06.021

39. http://www.uni-leipzig.de/ strahlen/web/research/en index.php, Megtekintve: 2015. 06. 10.

40. http://www.northropgrumman.com/Capabilities/GlobalHawk/Pages/default.aspx, Megtekintve: 2015 06. 10.

41. Murphy, D.M. and T. Koop, Review of the vapour pressures of ice and supercooled water for atmospheric applications. Quarterly Journal of the Royal Meteorological Society, 2005. 131(608): p. 1539-1565, DOI: 10.1256/qj.04.94

42.

http://faculty.eas.ualberta.ca/jidwilson/EAS372 13/Vomel CIRES satvpformul ae.html, Megtekintve: 2015. 06. 10.

43. Goff, J.A. and S. Gratch, Thermodynamic Properties of Moist Air. Am. Soc. Heating and Ventilating Engineers Trans, 1945. 125(51): p. 334-351 
44. Goff, J.A. and S. Gratch, Low-pressure properties of water from -160 to $212 \mathrm{~F}$. Transactions of the American society of heating and ventilating engineers, 1946. 52: $\mathrm{p}$. 95-122

45. Goff, J.A., Saturation pressure of water on the new Kelvin scale. Trans. Am. Soc. Heating Air-Cond. Eng., 1957(63): p. 347-354

46. http://www.phy.duke.edu/ hsg/363/table-images/water-phase-diagram.gif, Megtekintve: 2015. 06. 10.

47. Smit, H.G.J., S. Rohs, P. Neis, D. Boulanger, M. Krämer, A. Wahner, and A. Petzold, Technical Note: Reanalysis of upper troposphere humidity data from the MOZAIC programme for the period 1994 to 2009. Atmospheric Chemistry and Physics, 2014. 14(23): p. 13241-13255, DOI: 10.5194/acp-14-13241-2014

48. Rollins, A.W., T.D. Thornberry, R.S. Gao, J.B. Smith, D.S. Sayres, M.R. Sargent, C. Schiller, M. Krämer, N. Spelten, D.F. Hurst, A.F. Jordan, E.G. Hall, H. Vömel, G.S. Diskin, J.R. Podolske, L.E. Christensen, K.H. Rosenlof, E.J. Jensen, and D.W. Fahey, Evaluation of UT/LS hygrometer accuracy by intercomparison during the NASA MACPEX mission. Journal of Geophysical Research: Atmospheres, 2014. 119(4): p. 1915-1935, DOI: 10.1002/2013JD020817

49. http://cloud1.arc.nasa.gov/crystalface/presentations files/Posters/142 Weinstock Small.pdf, Megtekintve: 2015. 06. 10.

50. Fahey, D.W., R.S. Gao, O. Möhler, H. Saathoff, C. Schiller, V. Ebert, M. Krämer, T. Peter, N. Amarouche, L.M. Avallone, R. Bauer, Z. Bozóki, L.E. Christensen, S.M. Davis, G. Durry, C. Dyroff, R.L. Herman, S. Hunsmann, S.M. Khaykin, P. Mackrodt, J. Meyer, J.B. Smith, N. Spelten, R.F. Troy, H. Vömel, S. Wagner, and F.G. Wienhold, The AquaVIT-1 intercomparison of atmospheric water vapor measurement techniques. Atmospheric Measurement Techniques, 2014. 7(9): p. 3177-3213, DOI: 10.5194/amt-7-3177-2014

51. http://aquavit.icg.kfa-juelich.de/AquaVit/, Megtekintve: 2015. 06. 10.

52. http://aquavit.icg.kfajuelich.de/WhitePaper/AquaVITWhitePaper Final 230ct2009 22MB.pdf, Megtekintve: 2015. 06. 10.

53. http://www.imk-aaf.kit.edu/621.php, Megtekintve: 2015. 06. 10.

54. Wiederhold, P.R., Water Vapor Measurement: Methods and Instrumentation. 1997: CRC Press.

55. Ghafouri-Shiraz, H., Distributed feedback laser diodes and optical tunable filters. 2004: John Wiley \& Sons.

56. Zeller, W., L. Naehle, P. Fuchs, F. Gerschuetz, L. Hildebrandt, and J. Koeth, DFB lasers between $760 \mathrm{~nm}$ and 16 mum for sensing applications. Sensors (Basel), 2010. 10(4): p. 2492-510, DOI: 10.3390/s100402492

57. http://www.itu.int/en/ITU-T/publications/Pages/recs.aspx, Megtekintve: 2015 06. 10.

58. http://nanoplus.com/en/products/packaging-options/\#jumptab-2, Megtekintve: 2015. 06. 10.

59. Ebert, V., @ DENCHAR meeting, Szeged, Hungary. 2010 
60. Sarközy, L., @ AquaVIT2 measurement campaign, Karlsruhe, Germany. 2013

61. http://www.thorlabs.de/newgrouppage9.cfm?objectgroup id=6932, Megtekintve: 2015. 06. 10.

62. Mroziewicz, B., External cavity wavelength tunable semiconductor lasers - a review. Opto-Electronics Review, 2008. 16: p. 347-366

63. Kasap, S.O., Optoelectronics and Photonics: Principles and Practices. 2001. PrenticeHall, New Jersey.

64. Klotzkin, D.J., Introduction to Semiconductor Lasers for Optical Communications. 2014, New York: Springer-Verlag.

65.

http://nanoplus.com/fileadmin/ processed/csm nanoplus DFB 1420nm tu ning bae3bf23cb.png, Megtekintve: 2015. 06. 10.

66. Buldyreva, J., N. Lavrentieva, and V. Starikov, Collisional Line Broadening and Shifting of Atmospheric Gases: A Practical Guide for Line Shape Modeling by Current Semiclassical Approaches. 2011: World Scientific.

67. Demtröder, W., Laser spectroscopy: basic concepts and instrumentation. 2013: Springer Science \& Business Media.

68. Dicke, R.H., The Effect of Collisions upon the Doppler Width of Spectral Lines. Physical Review, 1953. 89(2): p. 472-473, DOI: 10.1103/PhysRev.89.472

69. Galatry, L., Simultaneous Effect of Doppler and Foreign Gas Broadening on Spectral Lines. Physical Review, 1961. 122(4): p. 1218-1223, DOI: 10.1103/PhysRev.122.1218

70. Rautian, S.G. and I.I. Sobel'man, THE EFFECT OF COLLISIONS ON THE DOPPLER BROADENING OF SPECTRAL LINES. Soviet Physics Uspekhi, 1967. 9(5): p. 701, DOI: 10.1070/PU1967v009n05ABEH003212

71. Ngo, N.H., H. Tran, R.R. Gamache, and J.M. Hartmann, Pressure effects on water vapour lines: beyond the Voigt profile. Philos Trans A Math Phys Eng Sci, 2012. 370(1968): p. 2495-508, DOI: 10.1098/rsta.2011.0272

72. Hansford, G.M., R.A. Freshwater, L. Eden, K.F.V. Turnbull, D.E. Hadaway, V.P. Ostanin, and R.L. Jones, Lightweight dew-/frost-point hygrometer based on a surface-acousticwave sensor for balloon-borne atmospheric water vapor profile sounding. Review of Scientific Instruments, 2006. 77(1): p. 014502, DOI: 10.1063/1.2140275

73. http://www.npl.co.uk/upload/img/condensation hygrometer.jpg, Megtekintve: 2015. 06. 10.

74. Verver, G., M. Fujiwara, P. Dolmans, C. Becker, P. Fortuin, and L. Miloshevich, Performance of the Vaisala RS80A/H and RS90 Humicap Sensors and the Meteolabor "Snow White" Chilled-Mirror Hygrometer in Paramaribo, Suriname. Journal of Atmospheric and Oceanic Technology, 2006. 23(11): p. 1506-1518, DOI: 10.1175/jtech1941.1

75. Helten, M., H.G.J. Smit, W. Sträter, D. Kley, P. Nedelec, M. Zöger, and R. Busen, Calibration and performance of automatic compact instrumentation for the 
measurement of relative humidity from passenger aircraft. Journal of Geophysical Research: Atmospheres, 1998. 103(D19): p. 25643-25652, DOI: 10.1029/98JD00536

76. Kley, D. and E.J. Stone, Measurement of water vapor in the stratosphere by photodissociation with $\operatorname{Ly} \alpha(1216 \AA$ A) light. Review of Scientific Instruments, 1978. 49(6): p. 691-697, DOI: 10.1063/1.1135596

77. Meyer, J., C. Rolf, C. Schiller, S. Rohs, N. Spelten, A. Afchine, M. Zöger, N. Sitnikov, T.D. Thornberry, A.W. Rollins, Z. Bozóki, D. Tátrai, V. Ebert, B. Kühnreich, P. Mackrodt, O. Möhler, H. Saathoff, K.H. Rosenlof, and M. Krämer, Two decades of water vapor measurements with the FISH fluorescence hygrometer: a review. Atmos. Chem. Phys. Discuss., 2015. 15(5): p. 7735-7782, DOI: 10.5194/acpd-15-7735-2015

78. Hodgkinson, J. and R.P. Tatam, Optical gas sensing: a review. Measurement Science and Technology, 2013. 24(1): p. 012004, DOI: 10.1088/0957-0233/24/1/012004

79. Lackner, M., Tunable diode laser absorption spectroscopy (TDLAS) in the process industries - A review, in Reviews in Chemical Engineering. 2007. p. 65-147.

80. Rieker, G.B.,Wavelength modulation spectroscopy for measurements of gas temperature and concentration in harsh environments, PhD thesis, 2009, Stanford University

81. Tunable Diode Laser Spectroscopy: Theory and Background, 2012, Mettler-Toledo AG, http://lab.mt.com/MTPRO/E-

Book TDL PRO/Online/pdf/BO TDLS Booklet External.pdf, Megtekintve: 2015. 06. 10.

82. Buchholz, B., B. Kühnreich, H.G.J. Smit, and V. Ebert, Validation of an extractive, airborne, compact TDL spectrometer for atmospheric humidity sensing by blind intercomparison. Applied Physics B, 2012. 110(2): p. 249-262, DOI: 10.1007/s00340012-5143-1

83. Herriott, D.R. and H.J. Schulte, Folded Optical Delay Lines. Applied Optics, 1965. 4(8): p. $883-889$, DOI: $10.1364 /$ AO. 4.000883

84. http://www.daylightsolutions.com/assets/002/5190.pdf, Megtekintve: 2015. 06. 10.

85. Ebert, V., @ DENCHAR meeting, Braunschweig, Germany. 2011.

86. Klein, A., O. Witzel, and V. Ebert, Rapid, time-division multiplexed, direct absorptionand wavelength modulation-spectroscopy. Sensors (Basel), 2014. 14(11): p. 21497513, DOI: 10.3390/s141121497

87. O'Keefe, A. and D.A.G. Deacon, Cavity ring-down optical spectrometer for absorption measurements using pulsed laser sources. Review of Scientific Instruments, 1988. 59(12): p. 2544-2551, DOI: 10.1063/1.1139895

88. Paul, J.B., L. Lapson, and J.G. Anderson, Ultrasensitive absorption spectroscopy with a high-finesse optical cavity and off-axis alignment. Applied Optics, 2001. 40(27): p. 4904-4910, DOI: 10.1364/AO.40.004904

89. http://www.dropletmeasurement.com/airborne-instruments, Megtekintve: 2015. 06. 10. 
90. Bell, A.G., On the production and reproduction of sound by light. American Journal of Science, 1880. 20(118): p. 305-324, DOI: 10.2475/ajs.s3-20.118.305

91. Bell, A.G., Upon the production of sound by radiant energy. Philosophical Magazine and Journal of Science, 1881. 11: p. 510-528

92. McDonald, F.A. and G.C. Wetsel, Generalized theory of the photoacoustic effect. Journal of Applied Physics, 1978. 49(4): p. 2313-2322, DOI: 10.1063/1.325116

93. Rosencwaig, A., Photo-acoustic spectroscopy of solids. Review of Scientific Instruments, 1977. 48(9): p. 1133-1137, DOI: doi: 10.1063/1.1135213

94. Rosencwaig, A. and A. Gersho, Theory of the photoacoustic effect with solids. Journal of Applied Physics, 1976. 47(1): p. 64-69, DOI: 10.1063/1.322296

95. Szakáll, M., H. Huszár, Z. Bozóki, and G. Szabó, On the pressure dependent sensitivity of a photoacoustic water vapor detector using active laser modulation control. Infrared Physics \& Technology, 2006. 48(3): p. 192-201, DOI: 10.1016/j.infrared.2006.01.002

96. Schilt, S. and L. Thévenaz, Wavelength modulation photoacoustic spectroscopy: Theoretical description and experimental results. Infrared Physics \& Technology, 2006. 48(2): p. 154-162, DOI: 10.1016/j.infrared.2005.09.001

97. Saarela, J., J. Toivonen, A. Manninen, T. Sorvajärvi, and R. Hernberg, Wavelength modulation waveforms in laser photoacoustic spectroscopy. Applied Optics, 2009. 48(4): p. 743-747, DOI: 10.1364/AO.48.000743

98. Bozóki, Z., A. Pogány, and G. Szabó, Photoacoustic Instruments for Practical Applications: Present, Potentials, and Future Challenges. Applied Spectroscopy Reviews, 2011. 46(1): p. 1-37, DOI: 10.1080/05704928.2010.520178

99. Uotila, J., A new design of the differential photoacoustic gas detector combined with a cantilever microphone. The European Physical Journal Special Topics, 2008. 153(1): p. 401-404, DOI: 10.1140/epjst/e2008-00471-y

100. Sharpe, S.W., T.J. Johnson, R.L. Sams, P.M. Chu, G.C. Rhoderick, and P.A. Johnson, GasPhase Databases for Quantitative Infrared Spectroscopy. Applied Spectroscopy, 2004. 58(12): p. 1452-1461, DOI: 10.1366/0003702042641281

101. Miklós, A., P. Hess, and Z. Bozóki, Application of acoustic resonators in photoacoustic trace gas analysis and metrology. Review of Scientific Instruments, 2001. 72(4): p. 1937-1955, DOI: 10.1063/1.1353198

102. Mattiello, M., M. Nikles, S. Schilt, L. Thevenaz, A. Salhi, D. Barat, A. Vicet, Y. Rouillard, R. Werner, and J. Koeth, Novel Helmholtz-based photoacoustic sensor for trace gas detection at ppm level using GalnAsSb/GaAlAsSb DFB lasers. Spectrochim Acta A Mol Biomol Spectrosc, 2006. 63(5): p. 952-8, DOI: 10.1016/j.saa.2005.11.006

103. McQueen, D.H., A simplified open photoacoustic cell and its applications. Journal of Physics E: Scientific Instruments, 1983. 16(8): p. 738, DOI: 10.1088/0022$3735 / 16 / 8 / 007$

104. Silva, M.D.d., I.N. Bandeira, and L.C.M. Miranda, Open-cell photoacoustic radiation detector. Journal of Physics E: Scientific Instruments, 1987. 20(12): p. 1476, DOI: 10.1088/0022-3735/20/12/009 
105. Szakáll, M., J. Csikós, Z. Bozóki, and G. Szabó, On the temperature dependent characteristics of a photoacoustic water vapor detector for airborne application. Infrared Physics \& Technology, 2007. 51(2): p. 113-121, DOI: 10.1016/j.infrared.2007.04.001

106. Szakáll, M.,Diódalézeres fotoakusztikus berendezés légköri vízgőzmérésekhez., PhD thesis, 2005, University of Szeged

107. Hebert, G.K., in 129th AES Convention. 2010: San Francisco, CA, USA.

108. Matthey, R., C. Affolderbach, and G. Mileti, Methods and evaluation of frequency aging in distributed-feedback laser diodes for rubidium atomic clocks. Optics Letters, 2011. 36(17): p. 3311-3313, DOI: 10.1364/OL.36.003311

109. Mawatari, H., M. Fukuda, F. Kano, Y. Tohmori, Y. Yoshikuni, and H. Toba, Lasing wavelength changes due to degradation in buried heterostructure distributed Bragg reflector lasers. Lightwave Technology, Journal of, 1999. 17(5): p. 918-923, DOI: 10.1109/50.762912

110. Woodward, S.L., P. Parayanthal, and U. Koren, The effects of aging on the Bragg section of a DBR laser. Photonics Technology Letters, IEEE, 1993. 5(7): p. 750-752, DOI: 10.1109/68.229794

111. Chung, Y.C., J. Jichai, and L.S. Cheng, Aging-induced wavelength shifts in 1.5\&\#x003BC;m DFB lasers. Photonics Technology Letters, IEEE, 1994. 6(7): p. 792-795, DOI: $10.1109 / 68.311456$

112. Fukuda, M., F. Kano, T. Kurosaki, and J. Yoshida, Behaviour of lasing wavelength change during degradation in a buried-heterostructure (BH)-type DFB laser. Quality and Reliability Engineering International, 1995. 11(4): p. 295-297, DOI: 10.1002/qre.4680110414

113. Udem, T., R. Holzwarth, and T.W. Hansch, Optical frequency metrology. Nature, 2002. 416(6877): p. 233-237, DOI: 10.1038/416233a

114. Li, H., A. Farooq, J.B. Jeffries, and R.K. Hanson, Diode laser measurements of temperature-dependent collisional-narrowing and broadening parameters of Arperturbed $\mathrm{H} 2 \mathrm{O}$ transitions at 1391.7 and $1397.8 \mathrm{~nm}$. Journal of Quantitative Spectroscopy and Radiative Transfer, 2008. 109(1): p. 132-143, DOI: 10.1016/j.jqsrt.2007.05.008

115. Tátrai, D., Z. Bozóki, and G. Szabó, Method for wavelength locking of tunable diode lasers based on photoacoustic spectroscopy. Optical Engineering, 2013. 52(9): p. 096104-096104, DOI: 10.1117/1.OE.52.9.096104

116. Bozóki, Z., D. Tátrai, and G. Szabó, Eljárás és összeállitás hullámhossz-hangolható fényforrás hullámhosszának stabilizálására abszorpciós spektroszkópiai jeldetektálás alapján. 2015.

117. Tátrai, D., Z. Bozóki, H. Smit, C. Rolf, N. Spelten, M. Krämer, A. Filges, C. Gerbig, G. Gulyás, and G. Szabó, Dual-channel photoacoustic hygrometer for airborne measurements: background, calibration, laboratory and in-flight intercomparison tests. Atmospheric Measurement Techniques, 2015. 8(1): p. 33-42, DOI: 10.5194/amt8-33-2015 
118. http://www.fz-juelich.de/SharedDocs/Downloads/IEK/IEK-8/EN/ESF/ESF.pdf, Megtekintve: 2015. 06. 10.

119. http://www.enviscope.de/measurement-campaigns/eufar-denchar-ifcc/, Megtekintve: 2015. 06. 10.

120. http://www.enviscope.de/wp-content/uploads/2011/12/flight track denchar.png, Megtekintve: 2015. 06. 10.

121. Chen, H., J. Winderlich, C. Gerbig, A. Hoefer, C.W. Rella, E.R. Crosson, A.D. Van Pelt, J. Steinbach, O. Kolle, V. Beck, B.C. Daube, E.W. Gottlieb, V.Y. Chow, G.W. Santoni, and S.C. Wofsy, High-accuracy continuous airborne measurements of greenhouse gases (CO2 and $\mathrm{CH} 4$ ) using the cavity ring-down spectroscopy (CRDS) technique. Atmos. Meas. Tech., 2010. 3(2): p. 375-386, DOI: 10.5194/amt-3-375-2010

122. Crosson, E.R., A cavity ring-down analyzer for measuring atmospheric levels of methane, carbon dioxide, and water vapor. Applied Physics B, 2008. 92(3): p. 403-408, DOI: 10.1007/s00340-008-3135-y

123. http://www.pc104.org/, Megtekintve: 2015. 06. 10.

124. http://www.opto22.com/site/snap pac system.aspx, Megtekintve: 2015. 06. 10.

125. http://www.ni.com/singleboard/, Megtekintve: 2015. 06. 10.

126. http://www.ni.com/pdf/products/us/fullcriodevguide.pdf, Megtekintve: 2015. 06. 10.

127. http://www.ni.com/pdf/manuals/375052c.pdf, Megtekintve: 2015. 06. 10.

128. http://www.ni.com/datasheet/pdf/en/ds-316, Megtekintve: 2015. 06. 10.

129. http://www.ni.com/pdf/manuals/374238c.pdf, Megtekintve: 2015. 06. 10.

130. http://www.ni.com/datasheet/pdf/en/ds-221, Megtekintve: 2015. 06.10.

131. http://www.ni.com/pdf/manuals/375099b.pdf, Megtekintve: 2015. 06. 10.

132. http://www.ni.com/cms/images/devzone/tut/clip image002 20080930142341.jpg, Megtekintve: 2015. 06. 10.

133. http://www.analogtechnologies.com/document/ATLS250MA103.pdf, Megtekintve: 2015. 06. 10.

134. http://www.ti.com/lit/an/sbea001/sbea001.pdf, Megtekintve: 2015. 06. 10.

135. Ångström, A., On the Atmospheric Transmission of Sun Radiation and on Dust in the Air. Geografiska Annaler, 1929. 11: p. 156-166, DOI: 10.2307/519399

136. Ångström, A., On the Atmospheric Transmission of Sun Radiation. II. Geografiska Annaler, 1930. 12: p. 130-159, DOI: $10.2307 / 519561$

137. Tatrai, D., Z. Bozoki, G. Gulyas, and G. Szabo, Embedded system based data acquisition and control system for photoacoustic spectroscopic applications. Measurement, 2015. 63: p. 259-268, DOI: 10.1016/j.measurement.2014.12.028 